UNIVERSIDADE DE SÃO PAULO

INSTITUTO DE GEOCIÊNCIAS

\title{
ESTUDOS PETROGRÁFICOS E GEOCRONOLÓGICOS DO PROSPECTO MANKOMBITI, CINTURÃO DE FÍNGOÈ, PROVÍNCIA DE TETE, NOROESTE DE MOÇAMBIQUE
}

Laura Nilza Mendes Mahanjane

Orientador: Prof. Dr. Colombo Celso Gaeta Tassinari

\section{DISSERTAÇÃO DE MESTRADO}

Programa de Pós-Graduação em Geoquímica e Geotectônica

SÃO PAULO

2013 


\title{
ESTUDOS PETROGRÁFICOS E GEOCRONOLÓGICOS DO PROSPECTO MANKOMBITI, CINTURÃO FÍNGOÈ, PROVÍNCIA DE TETE, NOROESTE DE MOÇAMBIQUE
}

\author{
Dissertação apresentada no Instituto de Geociências \\ da Universidade de São Paulo para obtenção \\ Do Título de Mestre em Geociências
}

\begin{abstract}
Programa: Geoquímica e Geotectônica
Área de Concentração: Geotectônica
\end{abstract}

Orientador: Prof. Dr. Colombo Celso Gaeta Tassinari

\section{SÃo PAULO}

2013 


\section{Dedicatória}

Dedicatória especial para os meus filhos Adaeze Chinyimu Mahanjane e Bhonghani Mendes Mahanjane, que na sua inocência aguentaram a minha ausência por todo este período de formação. Meus amores, mamãe vos ama muito!

Ao meu marido Estevão Sitefane Mahanjane, pelo amor, apoio moral e paciência dada nestes longos meses de formação!

A minha Mãe Maria Alice Lourenço e á memória do meu amado Pai Norberto José da Conceição. 


\section{Agradecimento especial}

Ao meu orientador, Prof. Dr. Colombo Celso Gaeta Tassinari, por ter acreditado na minha capacidade e dado a oportunidade de realizar os estudos de pós-graduação, em nível de mestrado. Pela orientação incansável, pela paciência durante todas as fases deste trabalho, pela força e encorajamento. Do fundo do meu coração muito obrigado!

\section{Agradecimentos}

Em primeiro lugar ao nosso senhor Divino pela força e coragem que me deu, para poder aguentar tantos meses longe daqueles que são a minha vida, meus filhos.

Ao meu esposo Estevão Sitefane Mahanjane pela paciência, força que me deu durante a minha formação no exterior.

Um especial obrigado á minha Mãe Maria Alice Lourenço, que sempre em meio às dificuldades me deu escola.

Ao Ministério da Ciência e Tecnologia de Moçambique por ter me proporcionado a bolsa de estudos, sem qual não seria possível à realização deste grande sonho.

Aos professores do IGc, pelos ensinamentos, o meu muito obrigado, em especial aos Professores Jorge Bittencourt, Umberto Giuseppe Cordani, Wilson Teixeira, Caetano e Rômulo Machado. Ao Professor Daúde Liace Jamal (Universidade Eduardo Mondlane -Moçambique) pela força, e atenção dispensada, muito obrigada!

Aos técnicos do CPGeo, em especial a Gisele e ao Vasco, o meu muito obrigado pelos ensinamentos no laboratório bem como a ajuda dada durante a preparação de amostras.

As minhas queridas amigas Silvana e Roberta o meu obrigado especial, pela força e conselhos sábios para conseguir aguentar com o tranco aqui no Brasil, obrigada do fundo do coração.

A secretaria de pós-graduação Magali, Leonardo e Tadeu, muito obrigada.

Ao Patrício, Carlos Mário, Ezequiel e Donald, muito obrigado pelas discussões científicas para a obtenção de melhores resultados. 
Aos meus colegas de turma e da universidade em especial a: Natali (uma amiga que jamais esquecerei a sua amizade!), Claudia, Alexandra, Andreia, Soraya jamais esquecerei as nossas saidinhas para a diversão, sentirei saudades das empregretes (risos).

Ao Vicente, pela ajuda nas discussões acadêmicas que foram muito importantes e produtivas. Aos meus compatriotas e amigos Africanos: Salvador, Aníbal, Tomé, Tique, Carlos, Fátima Chaúque, Lucia, Aniceto, Daca, Milton, Binta, Aida, Papucides, Chicamisse, Emanuel, Maloa, Zavala e Inês muito obrigada pela amizade, sem amigos ninguém aguenta!

Aos amigos cruspianos: Iasmin Marino, Tatiana Tavares, Viviane, Mary, Fernanda, Josi, Williams, Andrés, Altda, Lina, Debora e Nádia meu muito obrigado, se me esqueci de alguém me perdoe, estão todos em meu coração!

Aos meus Irmãos: Maria Luisa Bila, José Mendes, Lourenço Mendes, Paulina Cau e Nilton Majante, aos meus cunhados e cunhadas, tio Luís, tio Dinho, o meu obrigado pela força! A Tia Alice, lembrar-me-ei das suas palavras sempre: "menina fica ai e só volta com diploma na mão", muito obrigado!

A minha cunhada Safira Mahanjane e seus filhos Djodjo, Wanja e Nádia por terem tido a paciência de cuidar daqueles que são a minha mina de ouro durante a minha ausência! Não tenho palavras para agradecer! Muito obrigada do fundo do coração!

A família Mahanjane em especial ao Mano Amós pela força e coragem, muito obrigada.

A dona Lucinda que com paciência cuidou dos meus filhos e da minha casa, na minha ausência, é difícil encontrar pessoas assim nos dias de hoje.

A todos que direta ou indiretamente contribuíram para que fosse possível a realização deste trabalho o meu obrigado! 
'Aprender é a única coisa de que a mente nunca se cansa, nunca tem medo e nunca se arrepende.

Leonardo da Vinci 


\section{RESUMO}

O cinturão Fíngoè é uma unidade tectônica do Supercontinente Gondwana Oeste composta por rochas supracrustais formadas há aproximadamente $1.33 \mathrm{Ga}$. Essas rochas são portadoras de mineralizações de $\mathrm{Au}, \mathrm{Cu}, \mathrm{Zn}, \mathrm{Pb}$ e $\mathrm{Fe}$. Com cerca de $150 \mathrm{~km}$ de comprimento, e orientado WSW-ENE, este cinturão estende-se desde o Monte Atchiza a oeste até cerca de $30 \mathrm{~km}$ para leste da vila de Fíngoè no norte de Moçambique e consiste de uma extensa variedade de rochas metassedimentares e metavulcânicas. O cinturão Fíngoè apresenta especialização metalogenética para $\mathrm{Au}$ e $\mathrm{Cu}$, que já foram explotados no passado em diversos locais. Muitos destes registros estão associados com magnetita e malaquita. Atualmente trabalhos de prospecção e pesquisa mineral têm sido realizados pela empresa de mineração African Queen Mines Ltda, através do projeto denominado de King Solomons, localizado na parte central do mesmo. A geologia da área abrangida pelo prospecto Mankombiti, mostra uma predominância de rochas carbonáticas, granitos e gabros. As rochas carbonáticas são consideradas importantes na gênese de depósitos tipo skarn e depósitos de substituição de metais de base e Au devido à sua natureza fortemente reativa.

Os dados geocronológicos realizados neste trabalho indicaram uma idade precisa para a rocha intrusiva granítica associada à mineralização de $1079,1 \pm 8,2 \mathrm{Ma}$, que poderia ser a idade da formação do skarn e consequentemente desta mineralização. Entretanto a idade obtida para o processo de alteração hidrotermal que afetou o gabro, na ordem de $657 \pm 36 \mathrm{Ma}$ e a idade modelo $\mathrm{Pb}-\mathrm{Pb}$ sugerida pelo modelo de Stacey e Kramers (1975) para a calcopirita da mineralização principal de $725 \mathrm{Ma}$, sugerem que a mineralização, do prospecto Mankombiti é neoproterozóica. Para melhor entendimento dos processos que estiveram envolvidos na formação deste depósito skarn, duas hipóteses são consideradas: (i) poderia ser admitida a presença de corpos graníticos intrusivos em $700 \mathrm{Ma}$, situados em profundidade, que não foram ainda caracterizados, como responsáveis pela fonte de calor necessária, (ii) pode ser admitida ocorrência de um evento distensional em 700 Ma que produziria um adelgaçamento da litosfera e a consequente ascensão da astenosfera, produzindo uma elevação do fluxo térmico gerando os fluidos mineralizantes necessários.

Palavras chave: Cinturão Fíngoè, prospecto Mankombiti, composição isotópica $\mathrm{Sr}, \mathrm{Pb}$ e $\mathrm{Nd}$, geocronologia, mineralizações de $\mathrm{Au}, \mathrm{Cu}, \mathrm{Zn}, \mathrm{Pb}$ e Fe. 


\section{ABSTRACT}

The Fíngoè belt is a tectonic unit of West Gondwana Supercontinent, comprised of supracrustal rocks formed at approximately $1.33 \mathrm{Ga}$. These rocks are carriers of $\mathrm{Au}, \mathrm{Cu}, \mathrm{Zn}, \mathrm{Pb}$ and $\mathrm{Fe}$ mineralization. With about $150 \mathrm{~km}$ long and oriented WSW- ENE, this belt extends from west of the Atchiza Mount to about $30 \mathrm{~km}$ east of the Fíngoè village in the north Mozambique, and consists of an extensive variety of metasedimentary and metavolcanic rocks. The Fíngoè metallogenic belt provides specialization for $\mathrm{Au}$ and $\mathrm{Cu}$, which have been exploited in the past in various locations. Many of these records are associated with magnetite and malachite. Currently, the prospecting and mineral exploration have been conducted by the African Queen Mines Ltd mining company, through a project called the King Solomons, located in the central part of it. The geology of the studied area shows a predominance of carbonate rocks, granites and gabbros. The carbonate rocks are considered important in the genesis of the skarn deposits type and deposits of replacement for base metals and Au due to its highly reactive nature.

The geochronological data performed in this work indicate a precise age of the $1079.1 \pm 8.2 \mathrm{Ma}$ for the intrusive granitic rock associated with mineralization, which could be interpreted as the age of the skarn and consequently of the mineralization. However the age obtained for the hydrothermal alteration that affected the gabbro at about $657 \pm 36 \mathrm{Ma}$ and the $\mathrm{Pb}-\mathrm{Pb}$ model age suggested by the model of Stacey and Kramers (1975) for primary chalcopyrite mineralization at $725 \mathrm{Ma}$, suggesting that the mineralization of the Mankombiti prospectus was developed during the Neoproterozoic time.

For understanding the processes that were involved in the skarn-type mineralization processes, two hypotheses are here considered: (i) could be admitted the presence of intrusive granitic rocks at $700 \mathrm{Ma}$, situated in depth, which have not yet been characterized, as responsible for the heat source required, (ii) may be admitted occurrence of an extensional event at $700 \mathrm{Ma}$ to produce a thinning of the lithosphere and the uplift of the asthenosphere, producing high thermal flows generating the mineralization fluids.

Key words: Fíngoè belt, Mankombiti prospectus, isotopic composition of the $\mathrm{Sr}, \mathrm{Pb}$ and $\mathrm{Nd}$ geochronology, mineralization of the $\mathrm{Au}, \mathrm{Cu}, \mathrm{Zn}, \mathrm{Pb}$ and $\mathrm{Fe}$. 
Estudos Petrográficos e Geocronológicos do Prospecto Mankombiti, Cinturão de Fíngoè, Província de Tete Noroeste de Moçambique.

\section{ÍNDICE}

Dedicatória .. $\mathrm{i}$

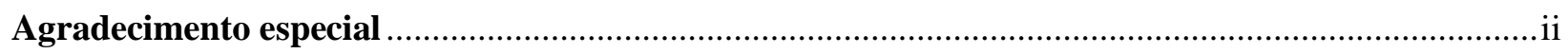

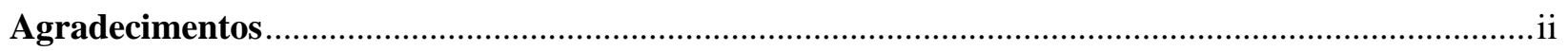

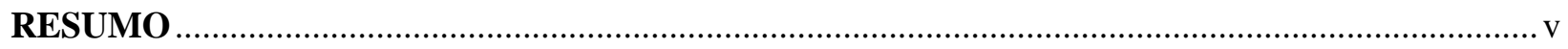

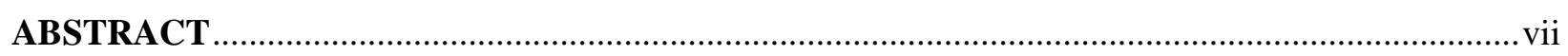

1- INTRODUÇÃ

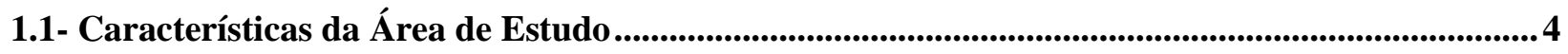

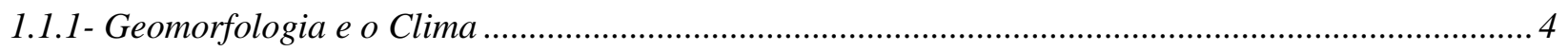

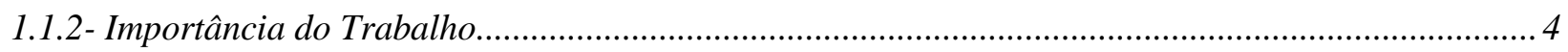

2- MÉTODOS DE TRABALHO, PROCEDIMENTOS ANALÍTICOS E FUNDAMENTOS

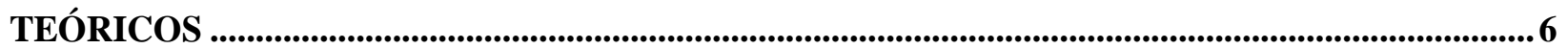

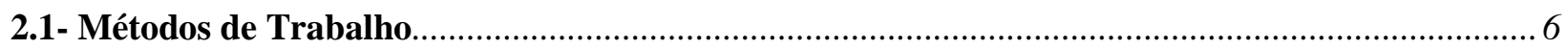

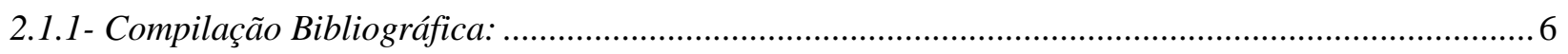

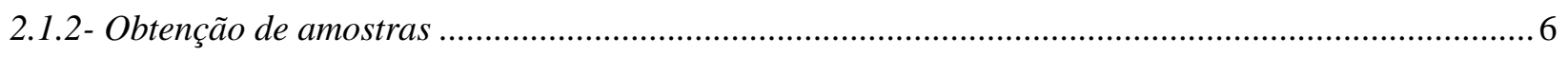

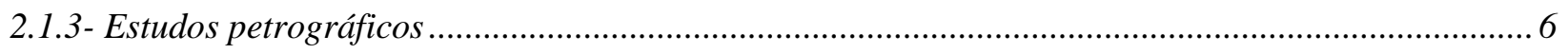

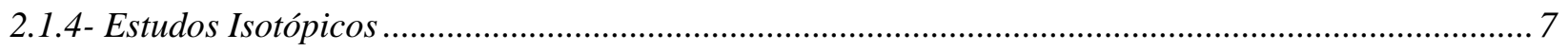

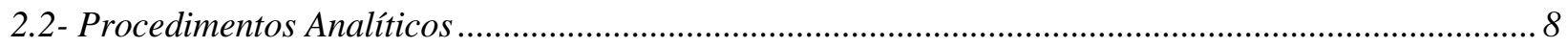

2.2.1 - Preparação de amostras para análises isotópicas.......................................................................... 8

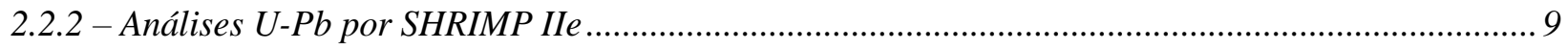

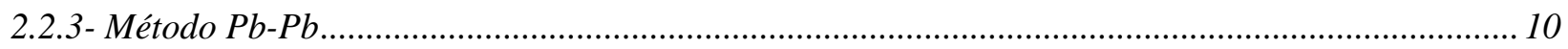

2.2.4- procedimentos de ataque químico por diluição isotópica $(\mathrm{Sm}-\mathrm{Nd}$ e $\mathrm{Rb}$-Sr)..................................11

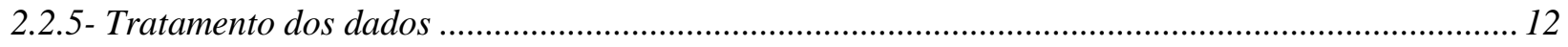

2.3 - Fundamentos Teóricos dos Métodos Isotópicos Utilizados ............................................................13

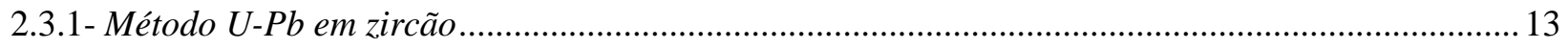

2.3.2-Metodo Rb-Sr em rocha total e minerais ...................................................................................... 14 
Estudos Petrográficos e Geocronológicos do Prospecto Mankombiti, Cinturão de Fíngoè, Província de Tete Noroeste de Moçambique.

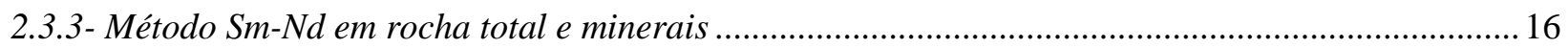

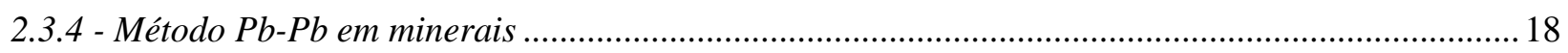

3- ENQUADRAMENTO GEOLÓGICO REGIONAL ....................................................... 20

3.1 Geologia regional e evolução tectônica.................................................................................................20

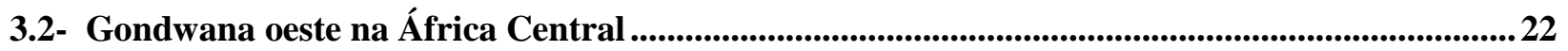

3.3- Cinturões Orogenicos Mesoproterozóicos ............................................................................................................22

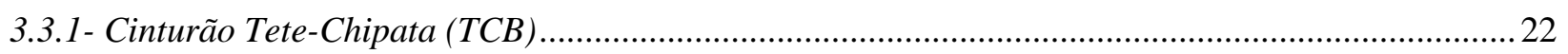

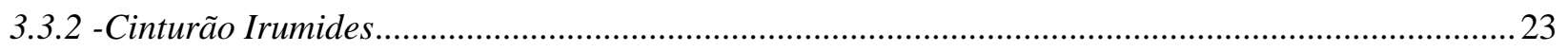

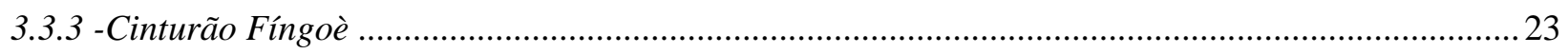

3.4 -Cinturões Orogenicos Neoproterozoicos.............................................................. 23

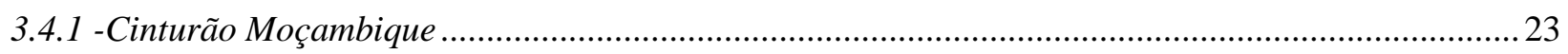

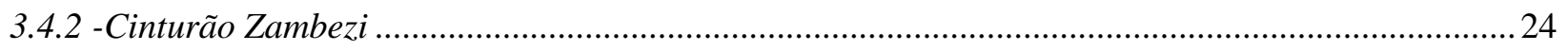

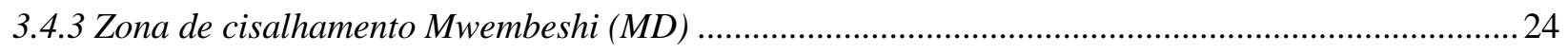

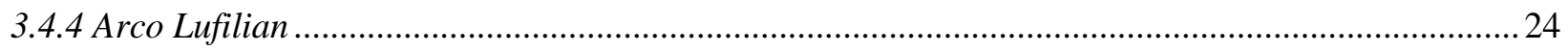

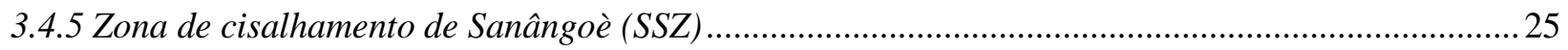

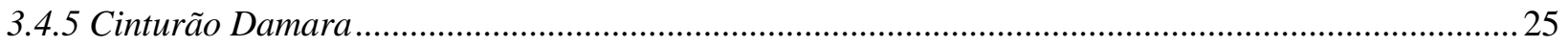

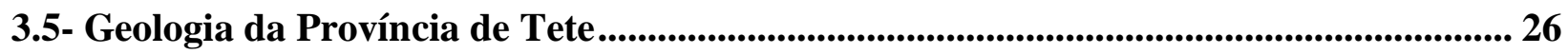

3.5.1 Rochas supracrustais Mesoproterozoicas .................................................................................2 26

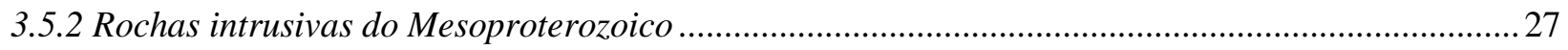

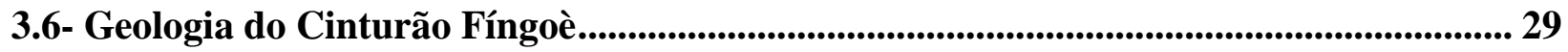

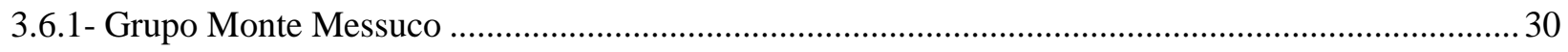

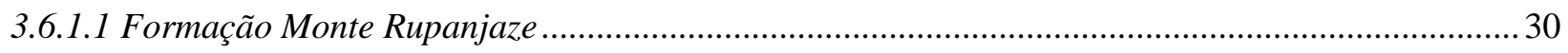

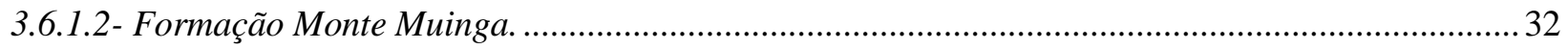

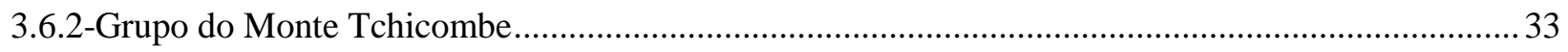

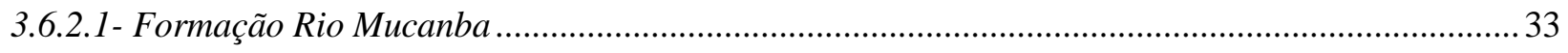

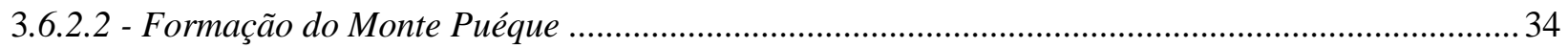


Estudos Petrográficos e Geocronológicos do Prospecto Mankombiti, Cinturão de Fíngoè, Província de Tete Noroeste de Moçambique.

3.7- Síntese de Dados Geocronológicos da Província de Tete.......................................................... 36

3.8- Aspectos Geológicos da Área de Estudo...........................................................................38

4. INTERPRETAÇÃO E DISCUSSÃO DOS RESULTADOS ................................................. 39

4.1 Caracteristicas Petrográficas e Mineralográficas do Mankombiti......................................................39

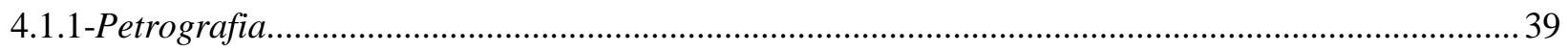

4.1.2-Unidades de mármores e Brechas do Monte Muinga..................................................................... 39

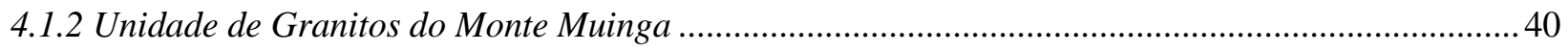

4.1.3- Unidade dos gabros do Monte Muinga ……………………………………………................ 42

4.2- Caracterização Mineralogica do Minério .................................................................................. 46

4.3 - Geocronologia e Geologia Isotópica.............................................................................................. 51

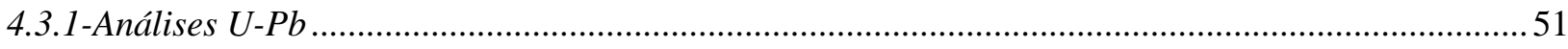

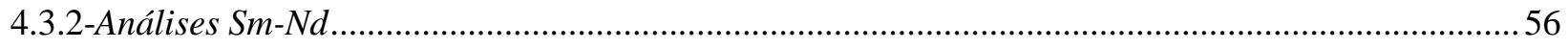

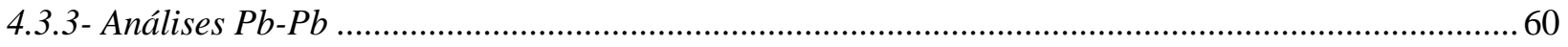

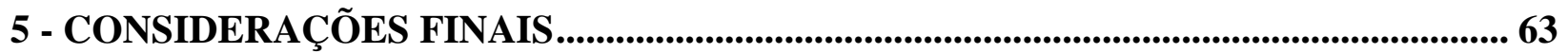

6 - REFERÊNCIAS BIBLIOGRÁFICAS.............................................................................69

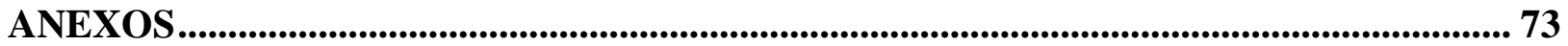




\section{ÍNDICE DE FIGURAS}

Figura 1- A- Mapa de África; B- Mapa de Moçambique com a localização de Furos de sondagem; C - Mapa de vias de acesso (linhas vermelhas) e distritos adaptado do Google Earth http://www.google.com.br/intl/pt-BR/earth/,06.10.13 ás 11h 42min; 3

Figura 2- Diagrama Uranogênico de Zartman \& Doe (1981) mostrando os quatro reservatorios geoquímicos da terra:Crosta Superior (CS), Orogênica (O), Manto (M) e Crosta Inferior (CI)...19

Figura 3 - Reconstrução do Gondwana. O modelo assume a colisão e fusão de três grandes placas litosféricas: Gondwana Leste, Oeste e Sul. Os orôgenos resultantes da colisão entre as três placas estão representados pelas cores vermelha (EAO) e azul (Kuunga). Moçambique esta apresentado na Figura, marcado com um retângulo, GTK Consortium (2006).

Figura 4 - Mapa geológico simplificado, mostrando os principais eventos resultantes da colisão do cráton do Congo e Kalahari. LTB- Cinturão Lúrio, SSZ-Zona de cisalhamento Sanangoé, MD-Deslocação de Mwembeshi Retirada do Westerhof et al (2008).

Figura 5- Mapa da província de Tete, NW de Moçambique mostrando as 3 placas litosfericas, e as rochas supracrustais Mesoproterozoicas, (Westerhof, 2008).

Figura 6 - Distribuição dos granitoides do Mesoproterozoico e suites bi-modais no cinturão de Tete-Chipata norte da Província de Tete (Westerhof, 2008). .28

Figura 7- Distribuição Pan -Africana dos granitóides e suites bi-modais do cinturão de TeteChipata. Retirada do GTK consortium (2006).

Figura 8- B: Mapa geológico de Tete; C: Mapa detalhado do cinturão Fíngoè, com a localização dos furos de sondagem, marcada por pontos pretos. .35

Figura 9 - Mapa Geológico com os dados Geocronológicos do Norte da Província de Tete .......37

Figura 10 - Mapa geológico do alvo Mankombiti (Christopher, P.A.; 2010). .38

Figura 11 - A. Textura granoblástica poligonizada nos mármores; B) Ilustração dos minerais de calcita (cc) e dolomita (Dlm) nas amostras de mármore;.C) brecha mostrando matriz fina, maciço, carbonatação fissural (Cal); D) orientação dos cristais da matriz carbonatica, mostrando alguns clastos de Piogenita (piog)...

Figura 12- A) cristais zonados de plagioclásio (Plg); B) alteração seletivamente pervasiva da clorita (chl) cristais de titanita (Tit) magmática e Microclinio (Mic); C) feldspato alcalino (Kdfs) com lamelas de exsolução; D) saussuritização de Plagioclásio no estilo seletivamente pervasiva, e cristas de anfibólio sendo alterado nas bordas e no núcleo, por epidoto. .42 
Figura 13- A) cristal de clinopiroxênio (cpx) sendo obliterado nas bordas por epidoto e cristal de epidoto resultante da alteração do clinopiroxênio; B e C) megacristal de plagioclásio e clinopiroxênio em matriz fina; com predomínio de plagioclásio. D) cristais de carbonato (Car), actinolita (Atc), opacos, com orientação dada pelos cristais de clorita (Chl) e alteração seletivamente pervasiva dada pelos mesmos minerais; E) megacristais de plagioclásio (Plg) em uma matriz cloritica sem orientação

Figura 14 - Microfotografia de minério disseminado na rocha. A) amostra MW03/017P B) MW05/001P.

Figura 15- Imagem de Microscopia Eletrônica de Varredura, brecha com calcopirita (Cpy), e Bornita (Bor) em forma de exsolução transversal a calcopirita e bornita na ganga associada à covelita. Minerais prismáticos de Piogenita (piog), em meio a uma estrutura maciça de calcopirita. .48

Figura 16. Imagem de Microscopia Eletrônica de Varredura de galena associada a bornita..........48

Figura 17- Imagem de Microscopia Eletrônica de Varredura de bismuto (Bis) tetraedrita, ocorrendo como exsolução na bornita e sem orientação.

Figura 18. Imagem de Microscopia Eletrônica de Varredura mostrando a prata (Ag) que ocorre associada ao telúrio em veios de quartzo e carbonato.

Figura 19- Imagem de Microscopia Elecrônica de Varredura de ouro (Au) associada a prata (Ag) em veios de quartzo e carbonato. .50

Figura 20-Imagem de Microscopia Eletrônica de Varredura mostrando a magnetita (Mag), associada à calcopirita (Cpy). .51

Figura 21- Imagens de catodoluminescência dos zircões analisados da amostra MW04/002P ....54

Figura 22- Média das idades ${ }^{207} \mathrm{~Pb} /{ }^{206} \mathrm{~Pb}$ dos zircões da amostra MW04/002P . .55

Figura 23 - Diagrama concórdia U-Pb para a amostra MW04/002P .................................................56

Figura 24- Diagrama isócronico Sm-Nd do Gabro do Monte Muinga …………………………......58

Figura 25. Diagrama isócronico Sm-Nd para o Gabro do Monte Muinga ………………………......59

Figura 26- Diagrama Uranogênico de Zartman \& Doe (1981) mostrando as curvas de evolução de $\mathrm{Pb}$ na Crosta Superior (CS), Crosta Inferior (CI), Manto (M) e Orogênica (O). São indicadas as composições isotópicas de sulfeto e calcita.

Figura 27-Diagrama ${ }^{206} \mathrm{~Pb} /{ }^{204} \mathrm{~Pb} v{ }^{207} \mathrm{~Pb} /{ }^{204} \mathrm{~Pb}$, para a calcopirita. A curva de evolução isotópica de $\mathrm{Pb}$ de Stacey \&Kramer (1975) esta lançada para a referência. 

Noroeste de Moçambique.

Figura 28- Modelos de ambientes tectônicos de formação de skarns; (A) Arco de ilha oceânica associados depósitos de carbonato íngremes; (B) Ambientes de subducção continental (C) Ambientes transicional de baixo ângulo; (D) Rifteamento continental definição com intrusões graníticas associadas a plumas do manto, Meinert et al.(2005)..........................................................66 


\section{ÍNDICE DE TABELAS}

Tabela 1. Relação das amostras para análises isotópicas............................................................... 8

Tabela 2-Descrição lito-estratigráfica das Formações Geológicas na Área de Estudo a partir de informação contida no mapa 1:250.000. (GTK consortium, 2006).

Tabela 3- Síntese de dados geocronológicos $\mathrm{U} / \mathrm{Pb}$ em Zircão e $\mathrm{Sm} / \mathrm{Nd}$ de rochas Mesoproterozóicas e Neoproterozoicas no NW de Moçambique-Província de Tete - Mänttäri (2008) .36

Tabela 4- Dados analíticos U/Pb (SHRIMP) …………………………………………………... 53

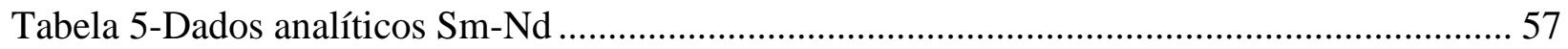

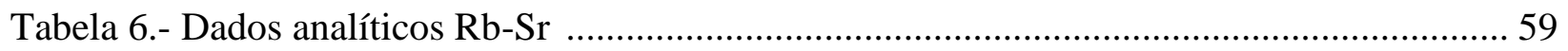

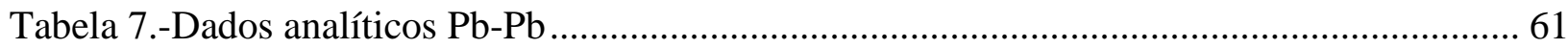




\section{Lista de siglas e abreviaturas}

$\mathrm{Au}-$ Ouro

BABI- Basalt Chondritic Best Inicial

CHUR- Chondritic Uniform Reservoir

$\mathrm{Cu}$ - Cobre

DNG- Direção Nacional de Geologia

EAAO - East África Antarctica Orogen

EDS - Energy Dispersive X- Ray Spectrometer

ENE- Leste - Nordeste

Fe-Ferro

Fig. - Figura

$\mathrm{Ga}$ - Giga anos

GTK- Geological Survey of Finland

IGc- Instituto de Geociências

IOCG-iron oxide-copper-gold

Km - Quilômetros

Ltda - Limitada

Ma- Milhões de anos

MEV - Microscópio Eletrônico Varredura

Mm- milímetros

MRMP- Projeto de Capacitação em Gestão dos Recursos Minerais 
NW- Noroeste

Nd- Nudíneo

$\mathrm{Pb}-$ Chumbo

Plg- Plagioclásio

Px-Piroxênio

RTO- Rocha Total

Sr- Estrôncio

SHRIMP- sensitive high resolution ion microprobe

U- Urânio

USP - Universidade de São Paulo

WSW - Oeste- Sudoeste

Zn- Zinco 


\section{1- INTRODUÇÃO}

A presente dissertação é resultado da cooperação Brasil- Moçambique, para desenvolvimento do conhecimento Geológico do território moçambicano, contando com o apoio da Universidade de São Paulo e do Ministério da Ciência e Tecnologia de Moçambique. Apesar de ocorrer alguns progressos nos estudos geológicos e mineiros na região norte do país, os dados geológicos disponíveis sobre as mineralizações com particular destaque para a província de Tete, ainda são incipientes. Nesta província ocorrem vários tipos de mineralizações, tais como; Ouro (Au), Cobre $(\mathrm{Cu})$, Zinco (Zn), Urânio (U), Ferro (Fe) e pedras preciosas e semipreciosas, bem como diversos minerais industriais e o carvão mineral (sendo o mais extraído) (GTK Consortium, 2006).

A área do presente estudo está localizada no distrito de Marávia, acima do Lago Cabora Bassa a Noroeste da Província de Tete, entre o coordenadas geográficas $15.41^{\circ} \mathrm{S}$ de latitude e $31.38^{\circ} \mathrm{E}$ longitude (Fig.1). O acesso á área é feito através uma estrada Nacional, duas estradas rurais terciárias, não classificadas, em um percuso de $200 \mathrm{~km}$ desde a cidade de Tete, capital provincial de Tete. O cinturão Fíngoè, onde se localiza a área de estudo, é composto por rochas supracrustais de idade Mesoproterozoica (GTK Consortium, 2006). As rochas supracrustais deste cinturão consistem de rochas metavulcânicas e rochas metassedimentares, granitos intrusivos e rochas gabróicas. Esta sequência metavulcano-sedimentar encontra-se exposta em um cinturão dobrado estreito, com $150 \mathrm{Km}$ de extensão e $30 \mathrm{~km}$ de largura, orientado WSW-ENE desde o Monte Atchiza a Oeste até Leste da vila de Fíngoè, com montes e cristas paralelas, as quais as distinguem das áreas graníticas adjacentes (GTK, consortium 2006).

Segundo este relatório, destaca-se no Cinturão Fíngoè a ocorrência de mineralizações de $\mathrm{Au}, \mathrm{Cu}$, $\mathrm{Zn}, \mathrm{Pb}$ e $\mathrm{Fe}$, que são pouco conhecidas sob o ponto vista metalogenético e potencial mineiro. $\mathrm{O}$ cinturão Fíngoè é prospectivo para depósitos do tipo IOCG em rochas metamórficas e elementos litofilos (tungstênio, estanho, etc) associados com rochas graníticas Tipo-I. Normalmente as mineralizações estão associadas a veios de quartzo, mas até o momento não foram encontradas quantidades economicamente interessantes.

Trabalhos de prospecção e pesquisa mineral foram recentemente realizados pela empresa de mineração African Queen Mines Ltda, através do projeto denominado de King Solomons, localizado na parte central deste cinturão. Este projeto teve seu inicio em julho de 2009, com a 
licença de exploração valida até Maio de 2015. Vários prospectos foram definidos por esta empresa, dos quais três são alvos de estudo no presente pela empresa: (i) o alvo Makombiti, objeto deste estudo, produziu valores significantes de $\mathrm{Cu}$, $\mathrm{Au}$ e $\mathrm{Ag}$; (ii) o alvo Kazito, onde ocorrem mineralizações em zonas de cisalhamento, com malaquita e tremolita associadas à magnetita; (iii) e o alvo Eiland, que é considerado como continuação do alvo Kazito (Christopher, 2010).

Este trabalho foi conduzido de tal forma que se consiga responder algumas questões com destaque para as seguintes: 1) Quais os processos de alteração hidrotermal que ocorrem na área estudada? 2) Qual é a relação e quais são as idades do magmatismo e da mineralização existente? 3) Qual é a origem dos fluidos mineralizantes? 4) Qual é o tipo mais provável da mineralização existente? Para responder as questões acima colocadas foi necessário, caracterizar as composições isotópicas de $\mathrm{Pb}$ dos minerais de minério, de $\mathrm{Sr}$ e $\mathrm{Pb}$ dos minerais de ganga, e de $\mathrm{Nd}$ das rochas hospedeiras e de idade $\mathrm{U}-\mathrm{Pb}$ (SHRIMP) em zircão de rocha intrusiva, integrando estes dados com as informações geológicas disponíveis visando a definição de idades e de fontes de fluidos mineralizantes para uma melhor caracterização metalogenética da mineralização estudada.

Várias dificuldades foram enfrentadas no decorrer deste trabalho, tais como a falta de trabalho de campo para amostragem por parte da mestranda devido a problemas de saúde, o que condicionou a obtenção de amostras à boa vontade da empresa de mineração, onde poucas amostras foram disponibilizadas para este estudo. Além disto a carência de estudos geológicos na área e a consequente falta de bibliografia também dificultaram a interpretação dos dados aqui obtidos. 
Estudos Petrográficos e Geocronológicos do Prospecto Mankombiti, Cinturão de Fíngoè, Província de Tete Noroeste de Moçambique.

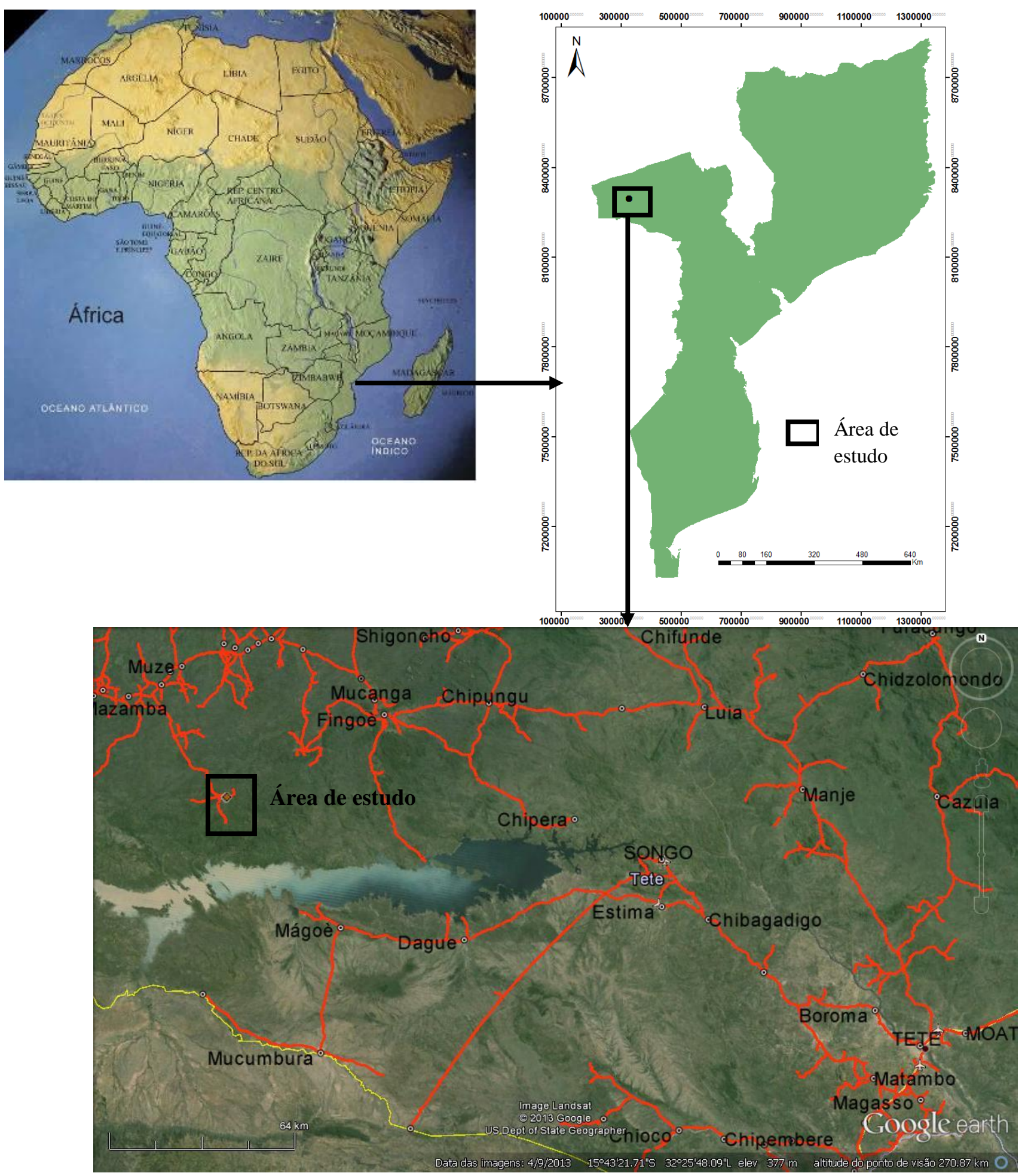

Figura 1- A- Mapa de África; B- Mapa de Moçambique com a localização de Furos de sondagem; C- Mapa de vias de acesso (linhas vermelhas) e distritos adaptado do Google Earth http://www.google.com.br/intl/ptBR/earth/,06.10.13 ás $11 \mathrm{~h} 42 \mathrm{~min}$; 
Esta dissertação é composta por 5 capitulos como se seguem: Capítulo 1: Introdução; Capítulo 2

Métodos de trabalho, procedimentos analíticos e fundamentos teóricos; Capitulo 3:

Enquadramento Geológico regional; Capitulo 4: Interpretação e Discussão dos resultados;

Capitulo 5: Considerações finais; Capitulo 6: Referências Bibliográficas.

\section{1- Características da Área de Estudo}

\subsection{1- Geomorfologia e o Clima}

Geomorfologicamente, a área de estudo é dominada por relevo colinoso a montanhoso, com altitudes que variam de 100 a 1.100 m. Os solos são argilosos à franco-argilosos de profundidade média nos locais mais planos. Nas colinas, os solos são pedregosos e pouco profundos. Segundo a Carta Nacional de Solos, os solos são argilosos vermelhos a castanho-avermelhados, profundos a pouco profundos nas encostas superiores dos declíveis, bem drenados e com muita probabilidade de estarem sujeitos a erosão.

O clima do distrito é do tipo temperado úmido, com duas estações distintas, a estação chuvosa e a estação seca.

A precipitação média anual é de cerca de $1.058 \mathrm{~mm}$. A precipitação ocorre nos meses de Novembro/Dezembro a Março/Abril, mais de 95\%. Os meses de Maio a Outubro são os mais críticos em termos de quantidade de preciptação, apenas cerca de 4-5mm caem em média anual durante este período, representando assim a estação seca, com cerca de 221 dias de duração, sendo o período intermédio de 28 dias, e cerca de 117 dias úmidos. A evapotranspiração potencial média anual é de cerca de $1.453 \mathrm{~mm}$. A temperatura média anual é de cerca de $22^{\circ} \mathrm{C}$, e a temperatura média das máximas anuais ronda aos $28^{\circ} \mathrm{C}$ e a mínima os $15^{\circ} \mathrm{C}$.

\subsection{2- Importância do Trabalho}

A motivação para este estudo deve-se ao fato do pouco conhecimento sobre o potencial mineral do Cinturão Fíngoè. Não obstante existe informação sobre algumas mineralizações que ocorrem neste cinturão e em outras áreas da região norte de Moçambique. Os estudos recentes demonstram ocorrências significativas de mineralizações de $\mathrm{Au}, \mathrm{Cu}, \mathrm{Zn}$, e Fe (GTK,consortium 2006). Os resultados desses estudos, trouxeram à luz novas percepções sobre as sequências tectono-estratigráficas, com base em dados geoquímicos e isotópicos. Acima de tudo esses dados contribuem para um melhor controle da geologia local.

Laura Nilza Mendes Mahanjane - Dissertação de Mestrado - Instituto de Geociências-USP 

Noroeste de Moçambique.

Entretanto, o trabalho realizado pela GTK, consortium (2006) não aborda com detalhe a gênese dessas mineralizações, sobretudo, nas ocorrências das mineralizações do Cinturão Fíngoè, que são associadas à sequências metavulcano-sedimentares.

Nesta dissertação, a partir de pesquisas bibliográficas e de análises petrográficas, minerográficas e isotópicas em uma suíte de amostras disponiblizadas pela empresa de mineração African Queen Mines Ltda procurou-se contribuir para o melhor enquadramento da mineralização de ouro e cobre na evolução tectono-metamórfica do Cinturão Fíngoè. 


\section{2- MÉTODOS DE TRABALHO, PROCEDIMENTOS ANALÍTICOS E FUNDAMENTOS TEÓRICOS}

\section{1- Métodos de Trabalho}

Neste capitulo enfatiza-se os fundamentos teóricos dos métodos isotópicos e procedimentos analíticos para este trabalho. Para atingir os objetivos propostos neste trabalho, foram utilizados diferentes materiais e métodos, conforme descrição a seguir:

\subsection{1- Compilação Bibliográfica:}

A compilação bibliográfica efetuada consistiu no levantamento e consulta das fontes bibliográficas sobre a geologia regional e local, compilação de dados pré-existentes da geocronologia, utilizando o acervo da biblioteca da Universidade Eduardo Mondlane de Moçambique, fontes disponíveis na internet, e informações geológicas provenientes da Direção Nacional de Geologia (DNG). Foram também consultados livros e artigos sobre os conceitos teóricos da aplicação da geoquímica isotópica de isótopos radiogênicos em processos hidrotermais associados à mineralizações de ouro e de metais de base, utilizando o acervo da biblioteca do IGc-USP, e internet.

\subsection{2- Obtenção de amostras}

As amostras para a realização deste estudo foram cedidas pela empresa de mineração African Queen Mines Ltd, que está realizando trabalhos de prospecção e pesquisa mineral na área deste estudo. Foi cedido um total de 15 amostras de rochas incluindo minérios, que foram estudadas do ponto de vista petrográficos, mineralógico e isotópico.

\subsection{3- Estudos petrográficos:}

Os estudos petrográficos foram realizados através de microscópio petrográfico de luz transmitida Zeiss Axioplan do laboratório de óptica do departamento de Mineralogia e Geotectônica, onde foram efetuadas descrições em 15 lâminas delgadas de rocha (cuja descrição detalhada de cada 
amostra se encontra em anexo - I), para identificar e caracterizar os principais tipos litológicos. As fotomicrografias foram obtidas no microscópio Olympus BPX50. Estes estudos permitiram, entre outras coisas, caracterizar as diferentes unidades litológicas da área. Duas amostras de minério foram estudadas através de secções polidas em microscópio Olympus BPX50 com sistema de analysis starter de luz refletida. Essas amostras foram também estudadas por Microscópio Eletrônico de Varredura (MEV), onde as duas secções polidas foram metalizadas com a película de carbono. A técnica do MEV baseia-se da matéria com elétrons excitados e destina-se a produção de imagens com aumentos de até 500 mil vezes. Os elétrons são produzidos em uma fonte de tungstênio aquecido e focalizados na amostra por meio de um sistema de lentes magnéticas. Através de um detector denominado EDS (Energy Dispersive XRay Spectrometer), são identificados os elementos presentes na amostra. Estas análises foram feitas no microscópio eletrônico de varredura de marca LEO, modelo 440 do Departamento de Mineralogia e Geotectônica do IGc-USP. Estes estudos foram feitos com o objetivo de caracterizar os minerais de minério e as relações entre minerais, como também caracterizar os materiais de preenchimento de fraturas e definir a forma de ocorrência do ouro.

\subsection{4- Estudos Isotópicos}

As amostras selecionadas para as análises isotópicas foram preparadas no laboratório do Centro de Pesquisas Geocronológicas (CPGeo) da Universidade de São Paulo.

As amostras foram preparadas para serem submetidas a análises pelos métodos $\mathrm{Sr}-\mathrm{Sr}$ em carbonatos, $\mathrm{Sm}-\mathrm{Nd}, \mathrm{Pb}-\mathrm{Pb}$ e $\mathrm{Rb}-\mathrm{Sr}$ em rocha total e em minerais separados e U-Pb por Microssonda Iônica de Alta Resolução do tipo SHRIMP IIe em zircão. O programa de análises isotópicas realizado e as amostras e materiais analisados com suas respectivas localizações em coordenadas UTM, constam da Tabela 1. 
Tabela 1. Relação das amostras para análises geocronológicas e isotópicas.

\begin{tabular}{|c|c|c|c|c|c|}
\hline \multirow[b]{2}{*}{$\mathbf{N}^{\circ}$ de campo } & \multirow[b]{2}{*}{ Rocha } & \multirow[b]{2}{*}{ Material } & \multirow[b]{2}{*}{ Método } & \multicolumn{2}{|c|}{ Coordenadas } \\
\hline & & & & $\mathbf{X}$ & $\mathbf{Y}$ \\
\hline MW05/001PO & $\begin{array}{l}\text { Brecha } \\
\text { carbonática }\end{array}$ & Sulfeto & $\mathrm{Pb}-\mathrm{Pb}$ & 326273 & 8295448 \\
\hline MW03/017PO & $\begin{array}{l}\text { Brecha } \\
\text { carbonática }\end{array}$ & Sulfeto & $\mathrm{Pb}-\mathrm{Pb}$ & 326273 & 8295273 \\
\hline MW02/029P & $\begin{array}{l}\text { Brecha } \\
\text { carbonática }\end{array}$ & Sulfeto & $\mathrm{Pb}-\mathrm{Pb}$ & 326357 & 8295307 \\
\hline MW06/001P0 & Micro Gabro & Sulfeto, RTO & $\mathrm{Pb}-\mathrm{Pb}, \mathrm{Rb}-\mathrm{Sr}$ & 326610 & 8295493 \\
\hline MW03/033PO & Micro Gabro & $\begin{array}{l}\text { Piroxênio, Plagioclásio, rocha } \\
\text { total }\end{array}$ & Sm-Nd & 326273 & 8295273 \\
\hline MW04/002P & Granito & Zircão & SHRIMP & 326273 & 8295273 \\
\hline ME05/003P & Micro Gabro & $\begin{array}{l}\text { Piroxênio, plagioclásio, rocha } \\
\text { total. }\end{array}$ & Sm-Nd & 326402 & 8295448 \\
\hline MW03/001P & Mármore & Calcita & $\mathrm{Sr}-\mathrm{Sr}, \mathrm{Pb}-\mathrm{Pb}$ & 326273 & 8295273 \\
\hline
\end{tabular}

\section{2- Procedimentos Analíticos}

\subsection{1- Preparação de amostras para análises isotópicas.}

Para as análises pelo método U-Pb (SHRIMP), e análises isotópicas $\mathrm{Sr}, \mathrm{Pb}$ e $\mathrm{Nd}$, prepararam-se amostras de rocha total e concentrados de minerais. As amostras de rocha total foram fragmentadas com martelo e depois trituradas em um pilão de aço, para a obtenção de frações de 60-100 mesh, em seguidas lavadas no ultrassom e secadas em lâmpadas aquecedoras. Para os concentrados de minerais se separou o anfibólio, zircão e sulfeto constituído principalmente pela calcopirita. Em cada amostra, depois de triturada e peneirada na fração granulométrica 60-100 mesh e 100-200 mesh, a fração magnética é retirada com íman de mão e em seguida com o separador eletromagnético tipo Frantz. Esta separação é completada quando o concentrado é separado por meio denso, usando líquidos pesados tais como o Bromofórmio: $\delta=2,82 \mathrm{~g} / \mathrm{cm}^{3}$ e o Iodeto de metileno: $\delta=3,32 \mathrm{~g} / \mathrm{cm}^{3}$. Estas amostras foram depois purificadas usando a catação manual, com auxílio de uma lupa binocular. 
Para a obtenção do concentrado de zircão a amostra passou pelo processo de britagem, moagem e peneiramento. Uma amostra foi selecionada para esta análise, e foi peneirada usando malhas de 60, 100, 250 e < 250 mesh, para a obtenção de frações de 100-250 e < 250 mesh. O material foi submetido a uma separação magnética com íman de mão, e depois pelo separador eletromagnético tipo Frantz com uma inclinação de $10^{\circ}$ e uma amperagem de 0.3 A. a fração usada é a não magnética e foi submetida ao líquido bromofórmio. O material pesado resultante deste procedimento é onde o zircão esta presente, e foi processado no iodeto de metileno. Após o processamento no iodeto de metileno o material foi novamente sujeito ao Frantz com uma amperagem de 1.0 A, e o zircão é encontrado na fração não magnética, assim como o é para os sulfetos.

\subsection{2 - Análises U-Pb por SHRIMP IIe}

Para as análises usando o método U-Pb em zircão através da microssonda iônica de alta resolução do tipo SHRIMP (sensitive high resolution ion microprobe) foram separados 84 grãos de zircão da amostra MW04/002P classificados em duas populações, após o seguimento dos procedimentos analíticos descritos em Sato et al (2008). Estes cristais, uma vez analisados, se separam por meio de catação manual usando a lupa binocular. Estes são depositados em disco de resina epox e polidos com abrasivos. As montagens das análises isotópicas U-Pb foram feitas no laboratório de geocronologia de alta resolução da Universidade de São Paulo.

As imagens de catodoluminescência dos cristais de zircão apresentam varias tipologias e hábitos. A escolha dos cristais é extremamente importante, pois o local de análise deve apresentar bandas de zoneamentos regulares, porque as áreas difusas são indicativas de ocorrência de perturbação (Sato et al., 2008)

O funcionamento do SHRIMP é baseado em feixes de íons de $\mathrm{O}^{2-}$ que atinge um mineral de zircão em pontos pré-determinados, gerando uma erosão parcial da superfície atacada de $<30$ $\mu \mathrm{m}$ de diâmetro. O material ionizado é levado e analisado no espectrômetro de massas (Ireland \& Williams 2003). A análise desta metodologia é complementada com o reconhecimento preliminar das estruturas internas dos minerais, sugerindo uma possível evolução do zircão mediante a obtenção de imagens de catodoluminescência. Estas imagens são geradas pela 
excitação da superfície do mineral antes da incidência de elétrons acelerados, a energia dissipada pelos átomos se apresenta nos espectros visíveis para gerar a imagem.

\subsection{3- Método Pb-Pb}

O método convencional $\mathrm{Pb}-\mathrm{Pb}$, através da dissolução total foi utilizado em amostras de calcopirita provenientes de brechas hidrotermais de composição carbonática e de micro gabros. O procedimento de rotina do CPGeo-USP, que foi seguido neste trabalho, para análises isotópicas de $\mathrm{Pb}$, encontra-se descrito em Babinski (1993) e apresentado a seguir:

Procedimentos das análises $\mathrm{Pb}-\mathrm{Pb}$ em sulfetos e calcita

Montagem de colunas

- Adicionar 5 gotas de resina, aguardar e escoar toda a água;

- Adicionar $2 \mathrm{ml}$ de $\mathrm{HCl} 6 \mathrm{M}$ e esperar escoar

- Adicionar $0.3 \mathrm{ml}$ de $\mathrm{H}_{2} \mathrm{O}$ e aguardar escoar;

- Adicionar $0.3 \mathrm{ml}$ de $\mathrm{HBr} 0.7 \mathrm{M}$ e escoar

Deposição e evolução das amostras de sulfetos em coluna de troca iônica

- Adicionar $0.3 \mathrm{ml}$ de $\mathrm{HBr}$ 0.7M em cada coluna e depois escoar

- Repetir a etapa anterior por duas vezes;

- Retirar os béqueres de descarte e substitui-los por savilex;

- Adicionar $1 \mathrm{ml}$ de $\mathrm{HCl} 6 \mathrm{M}$ em cada coluna esperar e depois escoar

- Adicionar $10 \mu \mathrm{l}$ de $\mathrm{H}_{3} \mathrm{PO}_{4}$ 0.1M diretamente no savilex

- Secar a amostra na chapa aquecedora

- Amostra pronta para a espectrometria. 


\subsection{4- Procedimento de ataque químico por diluição isotópica (Sm-Nd e Rb-Sr)}

Os procedimentos analíticos para as técnicas $\mathrm{Sm}-\mathrm{Nd}$ e $\mathrm{Rb}-\mathrm{Sr}$ seguidos rotineiramente no CPGeo-USP são descritos em detalhe em Sato et al. (1995) e Tassinari et. al. (1996). Nas amostras deste estudo os procedimentos realizados são apresentados a seguir:

- As amostras foram pesadas em savilex entre 50-200 mg de amostras, e anotar a pesagem;

- Foi adicionado Spike combinado de Sm-Nd, pesar e anotar a pesagem;

- Adicionou-se $1 \mathrm{ml} \mathrm{HNO}_{3}$ e 3ml HF (ácidos concentrados e destilados)

- O savilex foi aquecido a aproximadamente $100^{\circ} \mathrm{C}$ por 10 dias utilizando a chapa aquecedora;

- Após o aquecimento o savilex foi colocado para evaporar até a secura em chapa aquecedora $\left(60^{\circ} \mathrm{C}\right)$;

- Após evaporação, foi adicionado $6 \mathrm{ml}$ de $\mathrm{HCl} 6 \mathrm{M}$ e deixado aquecer por uma noite a $110^{\circ} \mathrm{C}$;

- Foi adicionado $1 \mathrm{ml} \mathrm{HNO}_{3}$ concentrado aos resíduos e evaporar até a secura;

- Foi encaminhado para a separação nas colunas;

Após a pulverização, as amostras são atacadas quimicamente em uma mistura de $1 \mathrm{ml} \mathrm{HNO}_{3} \mathrm{e}$ $3 \mathrm{ml} \mathrm{HF}$ e no final com $\mathrm{HCl}$ 6M para a eliminação de residuos (estes procedimentos encontramse detalhados em Sato et al., 1995). Posteriormente a extração de elementos de terras raras foi feita em colunas de troca catiônica com resina AG50WX8 (200-400 mesh) e diluição por HCl. O Sm e o Nd são separados para uma outra coluna usando o ácido di-etilexil fosfórico (HDEHP) suportado por um pó de teflon (200 mesh) e diluição com $\mathrm{HCl}$. As concentrações de $\mathrm{Sm}$ e $\mathrm{Nd}$ foram determinadas com a técnica de diluição isotópica usando um traçador misto de ${ }^{149} \mathrm{Sm}$ ${ }^{150} \mathrm{Nd}$, com uma concentração de ${ }^{150} \mathrm{Nd}$ de $0.0003314 \mathrm{mmol} / \mathrm{g}$ e teor de ${ }^{149} \mathrm{Sm}$ de $0.004575 \mathrm{mmol} / \mathrm{g}$. A determinação das razões isotópicas ${ }^{87} \mathrm{Sr} /{ }^{86} \mathrm{Sr}$ e ${ }^{143} \mathrm{Nd} /{ }^{144} \mathrm{Nd}$ é realizada em um espectrometro Triton e as análises foram controladas pelas leituras de padrão JNDI. As razões isotópicas ${ }^{143} \mathrm{Nd} /{ }^{144} \mathrm{Nd}$ (medidas como $\mathrm{Nd}^{+}$) foram normalizadas para o valor de ${ }^{146} \mathrm{Nd} /{ }^{144} \mathrm{Nd}=0,7219$ (De Paolo, 1981). O cálculo das idades são realizados com o ISOPLOT (Ludwig, 2003). 
Para o caso dos carbonatos, a separaçao de Sr é obtida pela técnica de troca catiônica em colunas de resina AG50WX8 após dissolução com $\mathrm{HF}-\mathrm{HNO}-\mathrm{HCl}$ a $80^{\circ} \mathrm{C}$. As razões isotópicas ${ }^{87} \mathrm{Sr} /{ }^{86} \mathrm{Sr}$ foram determinadas por espectrometria de massa de fonte sólida em um sistema de ultra-alto vácuo de $10^{-8}$ mbar, e $10 \mathrm{KV}$ de voltagem de aceleração, usando filamentos de Ta e

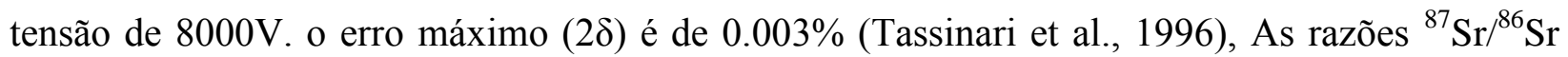
são corrigidas por fracionamento isotópico para ${ }^{87} \mathrm{Sr} /{ }^{86} \mathrm{Sr}=0.1194$ e o valor médio para esta mesma razão do padrão M3S-98.

\subsection{5- Tratamento dos dados}

Os dados isotópicos e geológicos obtidos foram tratados em diagramas apropriados usando vários softwares que são listados a seguir:

Microsoft Excel 2010 - para a elaboração de planilhas;

Microsoft Word 2010 - para a redação e formatação da dissertação;

Corel draw X3 - para o tratamento de fotografias e microfotografias;

Isoplot 3.0 - para o tratamento dos dados isotópicos e elaboração dos diagramas geocronológicos. Nas isócronas o cálculo de idade foi baseado no modelo de $2 \delta$ do programa isoplot;

ArcMap 10.1 - para a digitalização do mapa geológico da área de estudo e plot dos furos de sondagem que contém as amostras usadas neste trabalho. 


\section{3 - Fundamentos Teóricos dos Métodos Isotópicos Utilizados}

De acordo com Rutherford e Soddy (1902, apud Faure 2005) a teoria do decaimento radioativo, advoga que a razão de decaimento $(\lambda)$ de um átomo instável é proporcional ao número de átomos presentes $(\mathrm{N})$ em qualquer tempo $(\tau)$. Isto é matematicamente expresso em:

\section{$\lambda \mathbf{N}=-\mathbf{d N} / \mathbf{d} \tau$}

Deduzindo a equação acima se obtêm a equação fundamental da geocronologia, que descreve o decaimento de um radionuclídeo dentro de um espaço de tempo, onde o número de átomos radiogênicos presentes é zero ou conhecida e $\lambda$ constante ao longo do tempo geológico. Isto pode ser expresso por:

$$
\tau=1 / \lambda \ln (1+D / N)
$$

Onde: $\mathrm{D}=$ numero de átomos radiogênicos atuais e $\mathrm{N}=$ número de átomos radiativo atual.

Porém para a determinação das idades de um conjunto de amostras pelos métodos isotópicos, deve ter-se em conta algumas premissas: a) o sistema é fechado em relação aos átomos instáveis e estável; b) a constante de decaimento $(\lambda)$ deve ser conhecida; c) as amostras são cogenéticas (Faure, 2005). Portanto, as amostras que satisfazem essas premissas, os valores que resultam da análise isotópica definem arranjos lineares que obedecem à equação da reta $(\boldsymbol{y}=\boldsymbol{c}+\boldsymbol{x} \boldsymbol{m})$, de onde advém a equação:

$$
\mathbf{D}=\mathbf{D}_{\mathbf{0}}+\mathbf{n}\left(\mathbf{e}^{\lambda \tau}-\mathbf{1}\right)
$$

Onde $\mathrm{m}=\mathrm{e}^{\lambda \tau}-1 ; \mathrm{e} \mathrm{D}_{0}=$ intercepto no eixo $\mathrm{y}$

Todavia os resultados da reta pelos métodos $\mathrm{Sm}-\mathrm{Nd}$ e $\mathrm{Pb}-\mathrm{Pb}$ dão idades isocrônicas. Essas idades podem indicar: metamorfismo, cristalização, mineralização, alteração hidrotermal.

\subsection{1- Método $U$-Pb em zircão}

O zircão é um mineral acessório de rochas ígneas e metamórficas, predominando nos litotipos félsicos a intermediário. Este mineral resiste a altas temperaturas $\left(\sim 800^{\circ} \mathrm{C}\right)$, podendo perder $\mathrm{Pb}$ 
por processo de metamictização. A metamictização é resultado de danos no retículo cristalino causado durante a libertação de energia nos decaimentos radioativos de $\mathrm{U}$ e $\mathrm{Th}$ para $\mathrm{Pb}$ (Sato et $a l, 2008)$. Devido a esta alta temperatura de bloqueio, os zircões são capazes de preservar a idade de cristalização da rocha ígnea original, mesmo metamorfizadas em fácies anfibolíticas (Faure, 1986). Ocorrem naturalmente quatro isótopos de $\mathrm{Pb}\left({ }^{208} \mathrm{~Pb},{ }^{207} \mathrm{~Pb},{ }^{206} \mathrm{~Pb} \mathrm{e}{ }^{204} \mathrm{~Pb}\right)$, os três primeiros são produtos de decaimento de $\mathrm{U}$ e $\mathrm{Th}$, somente o ${ }^{204} \mathrm{~Pb}$ não é radiogênico e é tratado como isótopo estável (Faure, 1986; Dickin, 1995). O urânio ocorre como isótopos radiogênicos naturais de ${ }^{238} \mathrm{U},{ }^{235} \mathrm{U}$ e ${ }^{234} \mathrm{U}$, enquanto que o Th ocorre principalmente como ${ }^{232} \mathrm{Th}$. Muitos minerais formadores de rochas possuem baixas concentrações de Th, e em contrapartida o Th encontra-se concentrado em minerais acessórios tais como zircão, baddeleyita, titanita, monazita, apatita, allanita e perovskita. O U ocorre maioritariamente em rochas de composição ácida a intermediária e por vezes básicas. Este método é considerado um dos mais precisos e eficientes na determinação de idade de cristalização e eventos geológicos (Passarelli et al. 2009).

$\mathrm{O}$ princípio do método baseia-se no decaimento dos isótopos radiativos de ${ }^{235} \mathrm{U}$ e o ${ }^{238} \mathrm{U}$ para isótopos de ${ }^{207} \mathrm{~Pb}$ e ${ }^{206} \mathrm{~Pb}$. Os pares ${ }^{235} \mathrm{U}-{ }^{207} \mathrm{~Pb}$ e ${ }^{238} \mathrm{U}-{ }^{206} \mathrm{~Pb}$, fornecem separadamente idades independentes, e quando coincidem são chamados de idades concordantes. Quando representado graficamente ${ }^{235} \mathrm{U}-{ }^{297} \mathrm{~Pb}$ vs ${ }^{238} \mathrm{U}-{ }^{206} \mathrm{~Pb}$, os pontos das idades concordantes definem a curva designada concórdia. Todavia as idades discordantes entre os dois sistemas geralmente derivam da perda do $\mathrm{Pb}$, no mineral, e assim sendo, os pontos analíticos alinham-se em uma reta designada discórdia. Nos casos em que essa reta se intercepta com a curva define a idade de cristalização do mineral.

\subsection{2-Metodo $\mathrm{Rb}$-Sr em rocha total e minerais}

Rubídio e estrôncio são elementos-traço encontrados na maioria das rochas ígneas, metamórficas e sedimentares. Na geocronologia estes elementos são importantes baseando-se no princípio de que o isótopo radioativo ${ }^{87} \mathrm{Rb}$ decai para o isótopo estável ${ }^{87} \mathrm{Sr}$, através da emissão de partículas negativas $\beta$ e libertação de energia com a meia vida de $48.8 \mathrm{Ga}$ (Faure, 1986). Isto permite o aumento contínuo de ${ }^{87} \mathrm{Sr}$ em rochas ou minerais contendo $\mathrm{Rb}$, sendo possível o uso de ambos 
para a determinação de idades. Por outro lado, o isótopo radiogênico ${ }^{87} \mathrm{Sr}$ pode ser utilizado como um indicador em certos processos geológicos, tais como petrogenéticos, de depósitos minerais e na evolução isotópica dos oceanos através da equação:

$$
{ }^{87} \mathrm{Sr}={ }^{87} \mathrm{Sr}_{i}+{ }^{87} \mathbf{R b}\left(\mathrm{e}^{\lambda \tau}-1\right)
$$

Onde o ${ }^{87} \mathrm{Sr}$ é o numero total de átomos, ${ }^{87} \mathrm{Sr}_{i}$ é o numero inicial de átomos.

Segundo Faure (1986), dividindo cada membro da equação acima por ${ }^{86} \mathrm{Sr}$, porque este isótopo é estável e não é produzido por decaimento de um isótopo de ocorrência natural ou outro elemento, obtêm-se a equação base para a determinação da idade pelo método $\mathrm{Rb}$-Sr:

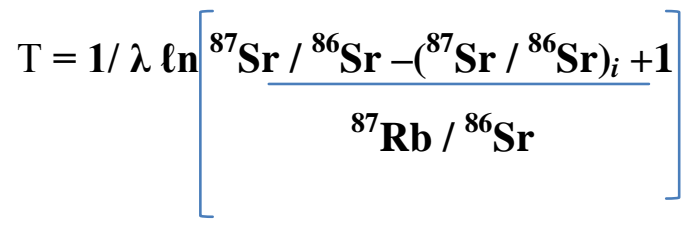

$\mathrm{O}$ valor aceito para o decaimento constante $\lambda=1,42 \times 10^{-11}$ anos $^{-1}$

Os minerais que se desenvolvem com razões ${ }^{87} \mathrm{Sr} /{ }^{86} \mathrm{Sr}$ altas, ao longo do tempo geológico tem razão inicial ${ }^{87} \mathrm{Sr} /{ }^{86} \mathrm{Sr}$ de 0,712 uniforme, e pode ser assumida em todos os cálculos de idades sem erros significativos. As idades determinadas usando esta razão inicial são chamadas de idade modelo, pois a razão inicial já é pré-definida em vez de medida diretamente. Mais tarde esse método foi estendido para rochas que contém minerais como a biotita, moscovita e K-feldspato (Dickin, 1995). Da equação linear y $=\mathrm{c}+\mathrm{xm}$ pode-se produzir o diagrama isocrônico ${ }^{87} \mathrm{Sr} /{ }^{86} \mathrm{Sr}$ (y) vs ${ }^{87} \mathrm{Rb} /{ }^{86} \mathrm{Sr}(\mathrm{x})$, em que os minerais co- magmáticos em um sistema fechado, tem a mesma idade e razão inicial $\left({ }^{87} \mathrm{Sr} /{ }^{86} \mathrm{Sr}\right)$, definindo uma linha designada por isócrona. A inclinação dessa linha, $\mathrm{m}=\mathrm{e}^{\lambda \tau}-1$ dá a idade do mineral. Se um desses minerais for muito pobre em $\mathrm{Rb}$ a sua razão inicial será medida diretamente (Dickin, 1995).

A razão ${ }^{87} \mathrm{Sr} /{ }^{86} \mathrm{Sr}$ da terra, no seu momento de formação, há $4.5 \mathrm{Ga}$. era de 0.6998 , e foi determinada em meteoritos, conhecida como BABI ou LUNI. Em função do decaimento radiativo do ${ }^{87} \mathrm{Rb}$ esta razão tem aumentado ao longo do tempo geológico e atualmente a razão ${ }^{87} \mathrm{Sr} /{ }^{86} \mathrm{Sr}$ média do manto é de $0,704 \pm 0.002$. A evolução do Sr no manto, desde seu estado inicial ao atual, é de caráter não linear, devido ao empobrecimento do Rb no manto e enriquecimento na crosta, por processos de diferenciação manto-crosta. 
Os diferentes ambientes geológicos também apresentam razões isotópicas distintas entre si, sendo que: Razão ${ }^{87} \mathrm{Sr} /{ }^{86} \mathrm{Sr}$ da crosta é maior do que a do manto, devido à partição preferencial de $\mathrm{Rb}$ para a crosta em relação ao $\mathrm{Sr}$. A composição isotópica $\mathrm{Sr}$ nos oceanos é determinada pelas contribuições relativas de $\mathrm{Sr}$ das águas fluviais $\left({ }^{87} \mathrm{Sr} /{ }^{86} \mathrm{Sr}=0.711\right)$ e fontes hidrotermais $\left({ }^{87} \mathrm{Sr} /{ }^{86} \mathrm{Sr}=0.703\right)$. A evolução do ${ }^{87} \mathrm{Sr} /{ }^{86} \mathrm{Sr}$ na crosta continental $\left[\left({ }^{87} \mathrm{Sr} /{ }^{86} \mathrm{Sr}\right)_{0}=0,700-0,706\right]$ e no manto $\left[\left({ }^{87} \mathrm{Sr} /{ }^{86} \mathrm{Sr}\right)_{0}=0,705-0,740\right]$, podem ser utilizado como traçador para determinar se um magma evoluiu a partir do manto, ou se crosta estava envolvida (Faure, 1986)

\subsection{3- Método Sm-Nd em rocha total e mineral}

Samário e Neodímio fazem parte do grupo de elementos de terras raras (ETRs) e possuem cinco e sete isótopos naturais respectivamente, dos quais em geocronologia e tectônica são usados o ${ }^{147} \mathrm{Sm}$ e o ${ }^{143} \mathrm{Nd}$. O Sm e o $\mathrm{Nd}$ tem raios iônicos similares, $1.04 \mathrm{~A}$ e $1.08 \mathrm{~A}$ respectivamente, e ocorrem em muitos minerais formadores de rochas substituindo íons maiores (Faure, 1986). A mobilidade dos ETRs em fluidos hidrotermais permite o fracionamento dos mesmos e consequentemente da razão $\mathrm{Sm} / \mathrm{Nd}$, tanto nas rochas como nos minerais de minérios. O maior fracionamento entre Sm e Nd ocorre durante a extração do magma a partir do manto. Processos na crosta incluindo fusão parcial e metamorfismo de alto grau costumam ter apenas um pequeno efeito sobre a sistemática $\mathrm{Sm} / \mathrm{Nd}$, o que torna o sistema Sm-Nd idealmente adequado para a determinação de idades modelo de extração do manto (De Paolo, 1988). Esse fracionamento permite em alguns casos, o cálculo de isócronas em minerais e nas rochas encaixantes, assim como a determinação do parâmetro $\varepsilon_{\mathrm{Nd}}$. As idades $\mathrm{Sm}-\mathrm{Nd}$ são obtidas através da construção de isócronas em amostras de rocha total ou de isócronas minerais, que permitem obter idades de cristalização magmática, de metamorfismo ou de alteração hidrotermal.

Sm-Nd ocorrem em minerais formadores de rocha como silicatos, fosfatos e carbonatos. A utilidade radiocronológica desses elementos se baseia no fato de que um isótopo de $\mathrm{Sm}\left({ }^{147} \mathrm{Sm}\right)$ é radiativo e sofre decaimento $\alpha$ para o isótopo de $\mathrm{Nd}\left({ }^{143} \mathrm{Nd}\right)$. Este decaimento ocorre numa faixa muito baixa, sendo a meia vida do ${ }^{147} \mathrm{Sm}$ próxima a $106 \mathrm{Ga}$, equivalente a um decaimento constante $\lambda$ de $6,54 \times 10^{-12} \operatorname{anos}^{-1}$ (Dickin, 1995). 
As idades isocrônicas em rocha total e em minerais, utiliza o mesmo princípio de $\mathrm{Rb}-\mathrm{Sr}$ e a equação é escrita com base no decaimento de ${ }^{147} \mathrm{Sm}:{ }^{143} \mathrm{Nd}={ }^{143} \mathrm{Nd}_{\mathrm{I}}+{ }^{147} \mathrm{Sm}\left(\mathrm{e}^{\lambda \tau}-1\right)$; onde I é abundância inicial e $\tau$ a idade do sistema. Dividindo a equação pelo segundo isótopo de ${ }^{144} \mathrm{Nd}$ mais abundante, obtêm-se a equação: ${ }^{143} \mathrm{Nd} /{ }^{144} \mathrm{Nd}=\left({ }^{143} \mathrm{Nd} /{ }^{144} \mathrm{Nd}\right)_{\mathrm{I}}+{ }^{147} \mathrm{Sm} /{ }^{144} \mathrm{Nd}\left(\mathrm{e}^{\lambda \tau}-1\right)$ que é a mesma obtida em $\mathrm{Rb}-\mathrm{Sr}$ e pode ser plotado como um diagrama isocrônico.

Durante o tempo geológico, o decaimento do ${ }^{147} \mathrm{Sm}$ resulta no aumento da abundância de ${ }^{143} \mathrm{Nd}$ em relação aos outros isótopos de $\mathrm{Nd}$. Desta forma o par $\mathrm{Sm}-\mathrm{Nd}$ constitui uma das mais importantes ferramentas geocronológicas com ampla aplicação na determinação de idades de rochas e na determinação temporal dos mais importantes eventos na evolução química do planeta que tem larga aplicação em rochas máficas e ultramáficas, visto serem constituidas pricipalmente por minerais com altas razões de $\mathrm{Sm} / \mathrm{Nd}$ (granadas, clinopiroxênios, anfibólio, biotitas e feldspatos).

A evolução isotópica do $\mathrm{Nd}$ é descrita em termos de modelos chamados CHUR (chondritic uniform reservoir), desde a formação da terra (Faure, 1986). Esse modelo assume que o $\mathrm{Nd}$ evoluiu a partir de um reservatório cuja razão $\mathrm{Sm} / \mathrm{Nd}$ é igual a dos meteoritos condríticos. O valor da razão ${ }^{143} \mathrm{Nd} /{ }^{144} \mathrm{Nd}$ é 0.512638 , relativo a razão ${ }^{146} \mathrm{Nd} /{ }^{144} \mathrm{Nd}$ de 0.7219 , e a razão ${ }^{147} \mathrm{Sm} /{ }^{144} \mathrm{Nd}$ de $C H U R$ é 0.1967 . Tendo essa informação é possível calcular o $C H U R$ em qualquer outro tempo $\tau$ no passado. Ao comparar a razão inicial ${ }^{143} \mathrm{Nd} /{ }^{144} \mathrm{Nd}$ das rochas da crosta terrestre com a razão ${ }^{143} \mathrm{Nd} /{ }^{144} \mathrm{Nd}$ do CHUR correspondente ao tempo de cristalização das rochas é obtido o parâmetro petrogenético épsilon $(\varepsilon)$ de $\mathrm{Nd}$. Este parâmetro é usado para determinar a idade de formação da rocha e permite fazer uma interpretação sobre a proveniência (fontes empobrecidas ou enriquecidas) da composição isotópica de $\mathrm{Nd}$.

$\mathrm{O}$ modelo de idades de manto empobrecido (depleted mantle $-D M$ ) apresentado por De Paolo (1981) representa a curva de evolução isotópica do Nd, a partir de amostras de basaltos do médio oceano (MORB) de idade arqueana, que ficam acima da curva de evolução CHUR (derivados do manto empobrecido). 
As idades modelos Sm-Nd calculadas usando a curva do depleted mantle são definidas como $T_{D M}$ e são mais precisas para o cálculo de idade de formação da crosta do que as idades $C H U R$, nos estudos da evolução continental (De Paolo,1981).

\subsection{4 - Método Pb-Pb em minerais}

Baseado nos decaimentos de ${ }^{235} \mathrm{U}$ e ${ }^{238} \mathrm{U}$, mas utiliza apenas dados de $\mathrm{Pb}$. Nier et al., (1941) apud Faure (1986), desenhou o modelo quantitativo para a evolução do $\mathrm{Pb}$ na terra, a partir do qual a idade da terra e a idade de minerais podem ser determinadas. Mais tarde Holmes (1946) e Houtermans (1946) apud Faure 1986, formularam de forma independente um modelo geral para a evolução do $\mathrm{Pb}$ na terra, que ficou conhecido como modelo Holmes- Houtermans. Este modelo assume que o $\mathrm{Pb}$ radiogênico é produzido por decaimento de $\mathrm{U}$ e Th nas regiões de origem e que o $\mathrm{Pb}$ resultante é então separado do radioativo (pai) e incorporado em depósitos de minério como galena. A composição isotópica de $\mathrm{Pb}$ na galena não muda pois esta não contém $\mathrm{U}$ ou Th. Segundo Faure (1986), este modelo foi posteriormente complementado por Stanton e Russsel, (1959) e Kanasewich (1968) e concluíram que a determinação de idades modelos é possível obedecendo algumas premissas: i) a terra foi um fluido homogêneo ii) $\mathrm{U}$, $\mathrm{Th}$ e $\mathrm{Pb}$ foram distribuídos uniformemente; iii) a composição isotópica de $\mathrm{Pb}$ é a mesma em toda a parte. Para a aplicação do modelo de Holmes- Houtermans (estagio único) assume-se que o sistema é fechado. De acordo com este modelo a equação usada para estimar a idade da terra com base na composição isotópica de $\mathrm{Pb}$ de uma amostra conhecida de galena é:

$\frac{\left({ }^{207} \mathrm{~Pb} /{ }^{204} \mathrm{~Pb}\right)_{\mathrm{t}}-b_{0}}{\left({ }^{206} \mathrm{~Pb} /{ }^{204} \mathrm{~Pb}\right)_{\mathrm{t}}-a_{0}}=\frac{1}{137,88}\left[\frac{\mathrm{e}^{\lambda \mathrm{T}}-\mathrm{e}_{2}^{\lambda \tau}}{\mathrm{e}^{\lambda \mathrm{T}}-\mathrm{e}^{\lambda \tau}{ }_{1}}\right]$

Onde: t é constante

Stacey \& Kramers (1975) propuseram um modelo de estágio duplo, em que o Pb desenvolveu-se em dois reservatórios com razões ${ }^{238} \mathrm{U} /{ }^{204} \mathrm{~Pb}$ e ${ }^{232} \mathrm{Th} /{ }^{204} \mathrm{~Pb}$ diferentes. No primeiro estágio a evolução do $\mathrm{Pb}$ começa com as razões isotópicas do $\mathrm{Pb}$ primordial do meteorito do Canyon Diablo no tempo $\mathrm{t}=4,57 \times 10^{9}$ anos e $\mu=7,192$. O segundo estágio iniciou no tempo $\mathrm{t}=3,70 \mathrm{x}$ $10^{9}$ anos, e $\mu=9,735$ depois da diferenciação geoquímica da terra. As isócronas $\mathrm{Pb}-\mathrm{Pb}$, são obtidas 
através de um conjunto de rochas e/ou minerais cogenéticos, em que as composições isotópicas se ajustam em linha reta do diagrama ${ }^{207} \mathrm{~Pb} /{ }^{204} \mathrm{~Pb}$ vs ${ }^{206} \mathrm{~Pb} /{ }^{204} \mathrm{~Pb}$.

Para a caracterização da origem de magmas e de fluidos hidrotermais através dos isótopos de $\mathrm{Pb}$ pode ser usado o modelo da plumbotectônica de Zartman e Doe (1981) (Fig.2). Este modelo descreve as curvas de evolução isotópica de $\mathrm{Pb}$ para os quatro reservatórios geoquímicos da terra: manto, crosta continental superior e inferior e ambiente orogenético. Estas curvas mostram a evolução da composição isotópica do $\mathrm{Pb}$ para estes reservatórios através do tempo geológico.

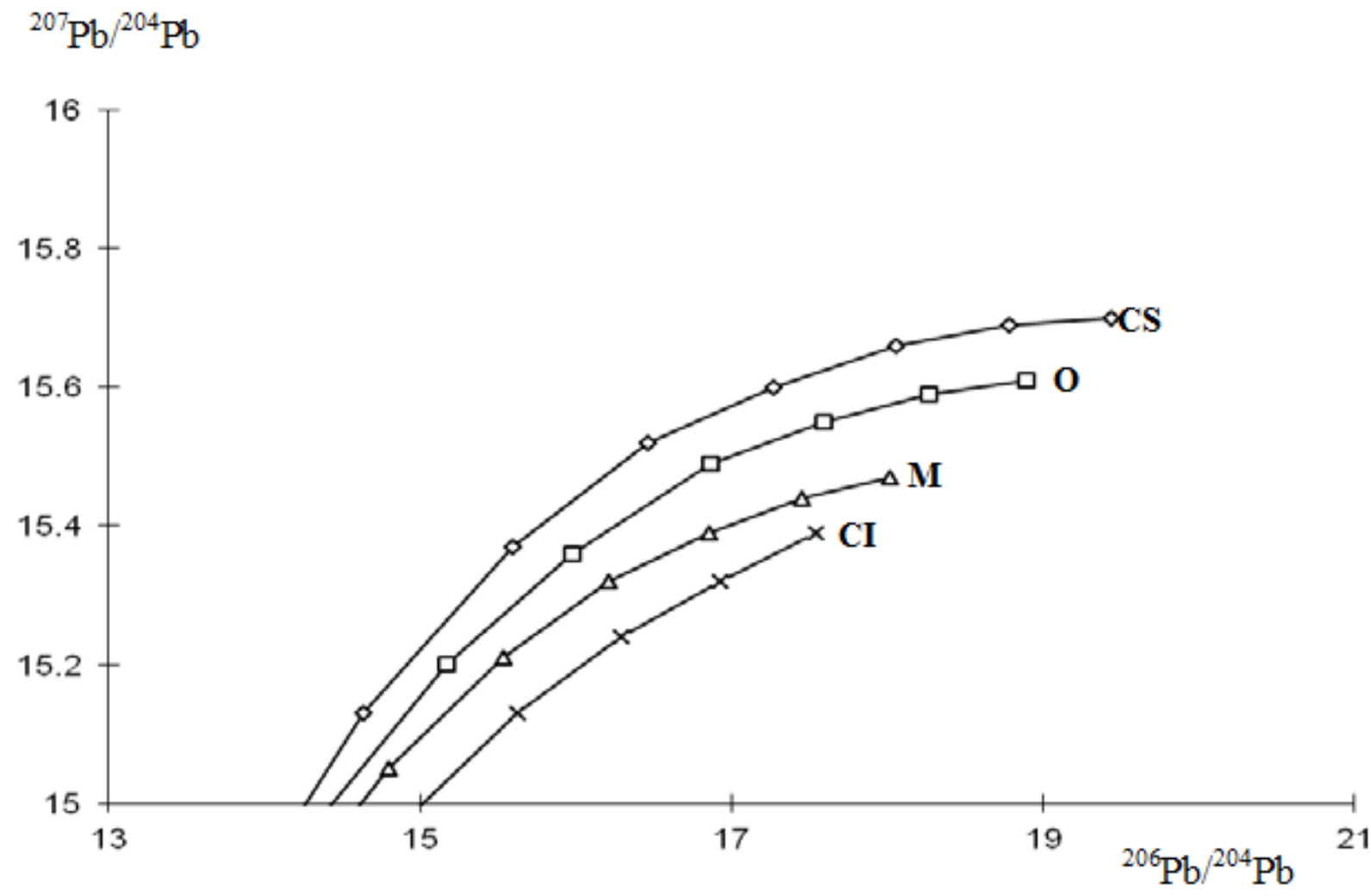

Figura. 2- Diagrama Uranogênico de Zartman \& Doe (1981) mostrando os quatro reservatórios geoquímicos da terra: Crosta Superior (CS), Orogênica (O), Manto (M) e Crosta Inferior (CI). 


\section{3- ENQUADRAMENTO GEOLÓGICO REGIONAL}

\subsection{Geologia regional e evolução tectônica}

A região norte de Moçambique está inserida em três placas litosfericas separadas por um mosáico de cinturões orogênicos proterozoicos. Estas placas litosfericas, designadas de Gondwana Oeste, Gondwana Leste e Gondwana Sul colidiram e almalgamaram durante o ciclo orogênico Pan-Africano, (Shacleton 1994, Grantham et al 2003).

A formação do supercontinente Gondwana, na África Austral e Oriental durante o ciclo orogênico Pan-Africano, envolveu dois principais eventos geodinâmicos (GTK Consortium, 2006). O primeiro evento incluiu o fechamento do oceano Moçambique entre 841 e $632 \mathrm{Ma}$ seguido de colisão e amalgamação ( 640 530 Ma) do Gondwana Oeste e Gondwana Leste (Jacobs et al., 2006). Neste modelo, o Gondwana Oeste incluia maior parte da África e América do Sul, e o Gondwana Leste era composto de crosta juvenil, agora atribuída ao Escudo ArabianoNubiano, e embasamento cristalino antigo de Madagáscar, Índia Antártica e Austrália. A colisão e amalgamação destas duas placas litosféricas criou um cinturão de dobra com direção N-S de $8000 \mathrm{~km}$ de extensão, chamado de Orogenia Leste Africana (Fig.3) ou, realçando sua continuidade mais para sul, Orogenia Leste Africana-Antártica (EAAO) (Jacobs et al., 2006) que está localizado na parte oriental do continente Africano e é adjacente ao Cráton de Sahara no norte de África, no centro ao Cráton de congo e no sul ao Cráton Zimbabwe. O segundo evento assume fechamento do oceano Zambezi-Adamastor e posterior colisão e amalgamação do Gondwana Oeste-Leste com o Gondwana Sul (GTK Consortium, 2006). Neste modelo o cinturão de dobra orientado N-S (Orogenia Leste Africana) envolveu-se com a orogenia Kuunga orientada E-W. Esta orogenia inclui (de oeste a leste) o cinturão Damara-Lufilian-Zambezi ( 850 - $450 \mathrm{Ma}$ ), o cinturão de Lúrio e, mais para leste, cinturões de Sri Lanka. Este sistema transcontinental separa o Cráton do Congo e o Cráton de Kalahari na África central.

A geologia do NW de Moçambique, onde se localiza a área de estudo, é inserida nos terrenos de Gondwana Oeste, e é atribuida a um terreno estrutural denominado Cinturão de Tete- Chipata. 


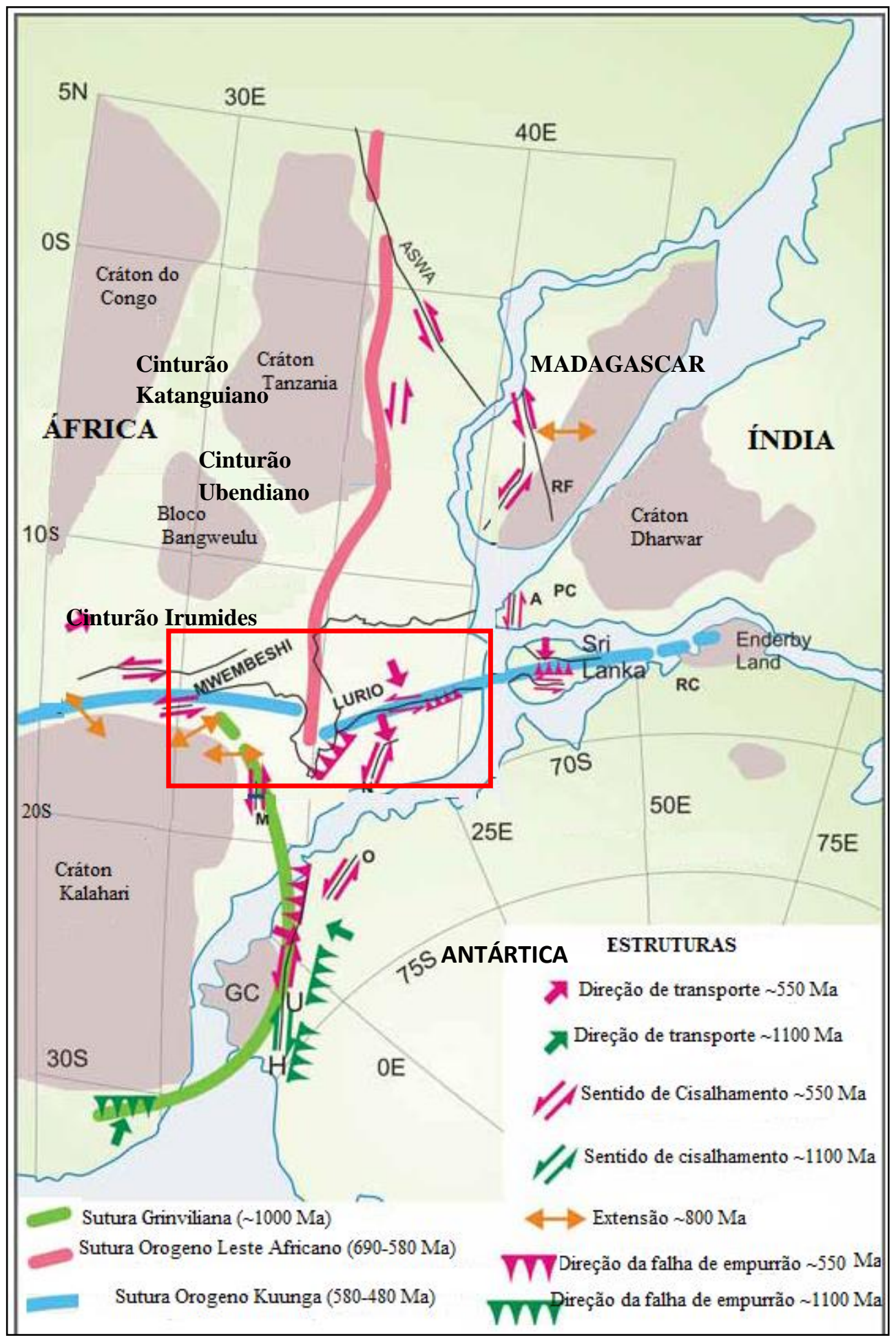

Figura 3 - Reconstrução do Gondwana. O modelo assume a colisão e fusão de três grandes placas litosféricas: Gondwana Leste, Oeste e Sul. Os orôgenos resultantes da colisão entre as três placas estão representados pelas cores vermelha (EAO) e azul (Kuunga). Moçambique esta apresentado na Figura, marcado com um retângulo, GTK Consortium (2006). 


\section{2- Gondwana oeste na África Central}

A África central compreende um mosáico de blocos cratonizados que estabilizaram a aproximadamente 2500 Ma (crátons de Zimbabwe e Congo) e um conjunto de unidades litoestratigráficas de cinturões móveis do proterozoico. Os cinturões móveis têm uma variedade de idades e podem ser agrupados em quatro períodos tectônicos: (i) formação dos cinturões paleoproterozoico (1660-1850 Ma); (ii) formação dos cinturões Mesoproterozoicos (11001300Ma); (iii) formação dos cinturões Neoproterozoicos (700 -850 Ma); e (iv) retrabalhamento e resfriamento Pan-Africano (450-650 Ma) (Goscombe et al; 1994). Destes períodos tectônicos são apenas descritos os cinturões do Mesoproterozoico, por possuirem idades concominantes ao cinturão Fíngoè onde se inseri a área de estudo, e cinturões e zonas de cisalhamento do Neoproterozoico adjacentes a área de estudo:

\section{3- Cinturões Orogênicos Mesoproterozóicos}

\subsubsection{Cinturão Tete-Chipata (TCB)}

O cinturão Tete-Chipata é limitado pela zona de cisalhamento de Sanângoè a sul, por terrenos de Gondwana Leste no leste e pela Zona de cisalhamento Mwembeshi no Nordeste. O embasamento cristalino do cinturão Tete-Chipata no norte da província de Tete, é composto por rochas supracrustais metamorfizadas e rochas plutônicas. Segundo Johnson et al.(2005), durante o ciclo orogênico Pan-Africano, o cinturão de Tete-Chipata, envolveu-se no orôgeno colisional DamaraLufilian-Zambezi (DLZ), que resultou da colisão entre os Crátons do Congo (Gondwana Oeste) e Kalahari (Gondwana Sul), após o fechamento da bacia oceanica do Zambezi-Adamastor, junto com uma série de unidades litoestratigraficas de cinturões dobrados, também resultantes dessa colisão (Fig.4). 


\subsubsection{Cinturão Irumides}

O cinturão Irumides no leste da Zâmbia é um dos inúmeros complexos cinturões orogênicos do Mesoproterozóico encontrados no continente Africano. Este localiza-se ao longo do flanco SE do cráton da Tanzânia-Bangweulu e a NW do cinturão Moçambique no leste da África. As características dominantes da tectônica são cisalhamentos dúcteis, empurrões e dobras relacionadas com eventos Mesoproterozóicos, de encurtamento crustal NW-SE e colocação de granitos de tectônica tardia. A principal deformação do Irumides acredita-se ter ocorrido entre 1100-950 Ma com o pico de metamorfismo entre 1050-1000 Ma (GTK consortium, 2006).

\subsubsection{Cinturão Fíngò̀}

Segundo a GTK consortium, (2006) as rochas supracrustais do cinturão dobrado Fíngoè, consistem de uma extensa variedade de rochas metassedimentares e metavulcânicas. Rochas vulcânicas xistentas e alguns micaxistos predominam na parte ocidental do cinturão, enquanto que gnaisses/xistos siliciosos portadores de epidoto, xistos quartzo-feldspáticos, várias rochas conglomeráticas e metavulcânicas, e algumas rochas carbonáticas predominam na parte central. As rochas vulcânicas, normalmente de origem piroclástica, caracterizam a parte oriental do cinturão dobrado. Para este cinturão foi obtida uma idade de $1327 \pm 16$ M.a, a partir de uma rocha metavulcânica.

\subsection{Cinturões Orogênicos Neoproterozóicos}

\subsubsection{Cinturão Moçambique}

Segundo Meert (2003) o cinturão Moçambique resultou de um evento tectônico que aconteceu entre 800 e 650 Ma, envolvendo colisão continente-continente entre Gondwana Leste e Oeste sendo designado EAAO. Em Moçambique esta orogenia é dissecada pelo cinturão Lúrio ao sul do qual é caracterizada por grandes volumes de granitoides tipo A de alta temperatura datados entre 530-490 Ma e associados a deformação extensional polifásica. 
Kroner \& Stern (2004), com base na distribuição de idades radiométricas de U-Pb em zircão, distinguiram dois picos, a 610 - $660 \mathrm{Ma}$ e 530 - $570 \mathrm{Ma}$ dos quais dois eventos orogênicos foram identificados: (i) a orogenia Leste Africana (610 - $660 \mathrm{Ma})$ e a (ii) orogenia Kuunga (530 - $570 \mathrm{Ma})$. O cinturão Moçambique consiste de gneisses de médio a alto grau e volumosos granitoides, e estende-se desde o escudo Arabiano-Nubiano até Moçambique.

\subsubsection{Cinturão Zambezi}

O cinturão Zambezi é parte da conexão dos cinturões orogênicos do NeoproterozoicoPaleozoico inferior que rodeiam e separam os crátons do Congo e do Kalahari. Consiste predominantemente de rochas de fácies anfibolíticas a granulíticas, orto e paragnaisses do Neoproterozoico inferior, intrudidos localmente por corpos acamadados de gabro anortosítico. Embora a maioria dos gnaisses deste cinturão mostrem idades entre 850-870Ma, são tectonicamente intercalados por gnaisses granitóides com idades U-Pb (zircão) em torno de 1100 Ma. O pico do metamorfismo Pan-Africano ocorreu em 540-535 Ma (Kroner \& Stern 2004). O Cinturão Zambezi está tectonicamente em contato com as rochas de baixo grau do Arco Lufilian, na Zâmbia ao longo da zona de cisalhamento transcorrente Mwembeshi (Goscombe et al; 2000).

\subsubsection{Zona de cisalhamento Mwembeshi (MD)}

A zona de cisalhamento Mwembeshi é uma zona de cisalhamento sinistral dúctil Pan-Africana regionalmente significante, que pode ser ligada a deformações tectônicas tardias no cinturão de DZL, durante a colisão obliqua entre os crátons de Congo e Kalahari. Esta forma um elemento estrutural fundamental no centro- sul de África e é datada em 550 Ma (Hanson et al 1993).

\subsubsection{Arco Lufilian}

O Arco Lufilian em Namíbia é interpretado como sendo uma continuidade do cinturão Damara, cuja principal unidade litoestratigráfica é Neoproterozóica. Este é composto por rochas vulcânicas datadas de 765-735 Ma. O metamorfismo ocorreu entre 566 -550 Ma (Kroner \& 
Stern, 2004). No Zimbabwe este arco é interpretado como área tipo do sistema Katanguiano, constituido por rochas do embasamento de idade Kibariana e cobertura meta-sedimentar do supergrupo Katanguiano (Wilson et al. 1997).

\subsubsection{Zona de cisalhamento de Sanângò̀ (SSZ)}

A Zona de cisalhamento Sanângoè é considerada como uma zona de falha transpressional PanAfricana, com aspectos estruturais mais ou menos similares a deslocação Mwembeshi. Esta zona, localiza-se dentro de uma zona de fraqueza no cinturão Zambezi, formando um limite mapeável entre o Gondwana sul e o Gondwana Oeste (Fig. 4) (Stern ,2004).

\subsubsection{Cinturão Damara}

O Cinturão Damara, está exposto no centro e norte de Namíbia. A principal unidade litoestratigráfica do cinturão Damara, que registra formação de bacias e rifts, têm o magmatismo em 760 Ma. A transpressão sinistral é vista como a causa deste evento orogênico, que teve o seu pico metamórfico em 550-520 Ma. Volumosos granitoides pré e sin-tectónicos, intrudiram a parte central do cinturão entre $\sim 650$ e $\sim 488 \mathrm{Ma}$, e granitos altamente diferenciados hospedam uma das maiores minas de urânio no mundo (Rössing), datados em 460 Ma,( Kröner \& Stern 2004). 


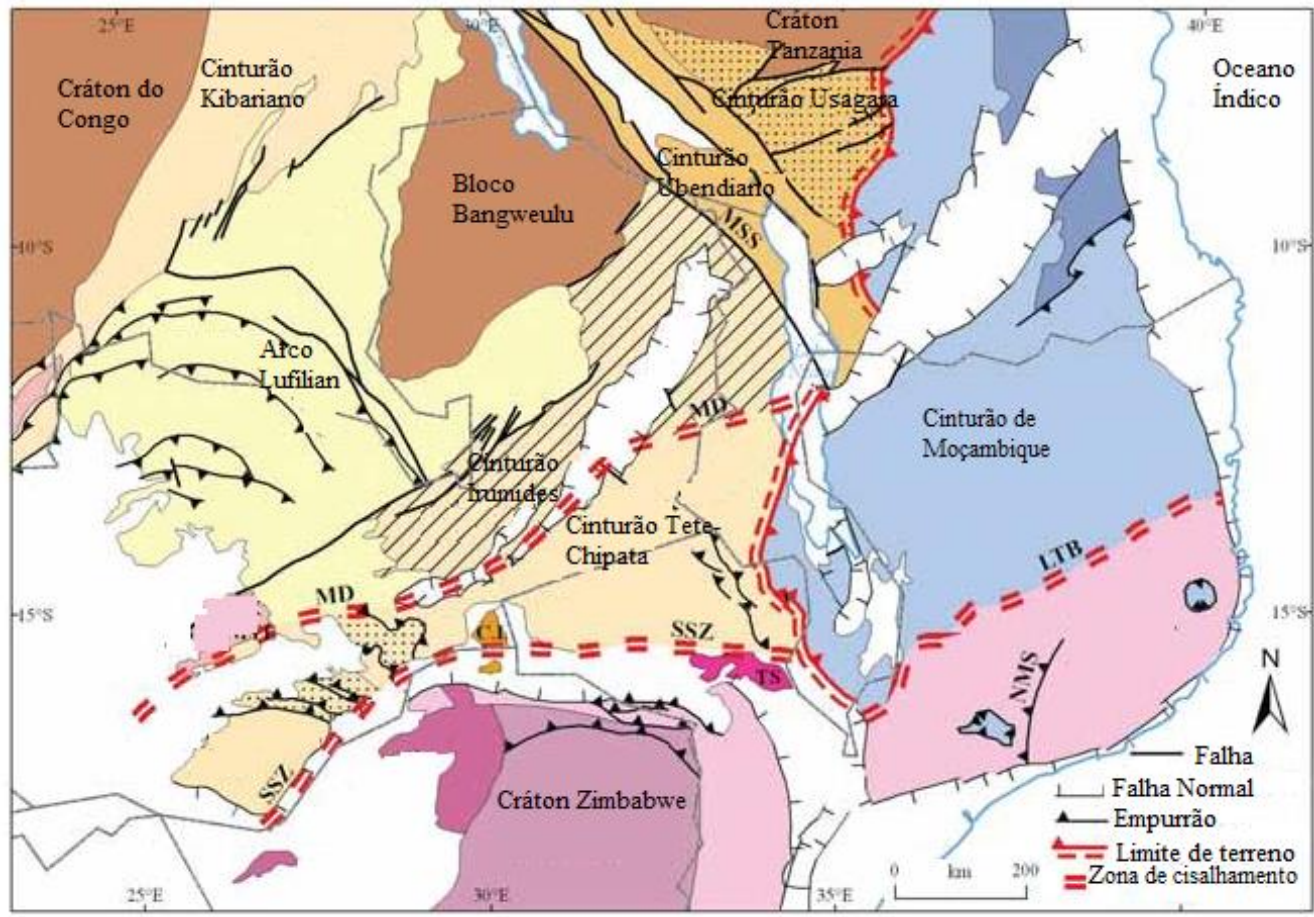

Figura 4 - Mapa geológico simplificado, mostrando os principais eventos resultantes da colisão do cráton do Congo e Kalahari. LTB- Cinturão Lúrio, SSZ-Zona de cisalhamento Sanangoé, MD-Deslocação de Mwembeshi Retirada do Westerhof et al (2008).

\section{5- Geologia da Província de Tete}

A Província de Tete, está localizada no centro-oeste de Moçambique. O embasamento cristalino desta província pertence a cada uma das placas litosfericas acima descritas (Fig. 5). A geologia do Norte da província de Tete, (parte da Provincia de Tete, pertecente ao Gondwana Oeste) pode ser enquadrado em três grupos (GTK consortium; 2006) de acordo com a sua litologia e idade, a saber: (i) rochas supracrustais Mesoproterozoicas, (ii) rochas intrusivas do Mesoproterozoico e (iii) rochas intrusivas Pan-Africanas.

\subsubsection{Rochas supracrustais Mesoproterozoicas}

As rochas supracrustais Mesoproterozoicas, podem ser agrupadas em 3 sub-grupos: (i) Sequência vulcano-sedimentar de $1.3 \mathrm{Ga}$ : composta predominantemente por uma variedade de rochas metassedimentares clásticas e carbonáticas intercaladas por metavulcanitos félsicos a 
ultramáficos e piroclásticos subordinadas, de carácter toleiítico, cuja associação com as rochas supracrustais lhe confere uma origem em arco de ilha oceânico. (ii) Sequências sedimentares de 1.2 - $1.3 \mathrm{Ga}$ : em que a base é dominada por para-gnaisses intercalados por horizontes finos de orto-quatzitos e rochas vulcânicas máficas. O topo é caracterizado por mármores e rochas calcosilicatadas com camadas subordinadas de quartzitos e meta-arcoses. (iii) Granulitos e gnaisses (> $1.08 \mathrm{Ga}$ ): granulitos derivados de rochas supracrustais de composição básica a intermédia pertencentes ao Grupo de Chidzolomondo ocupam uma extensa área do Gondwana Oeste (Fig.5).

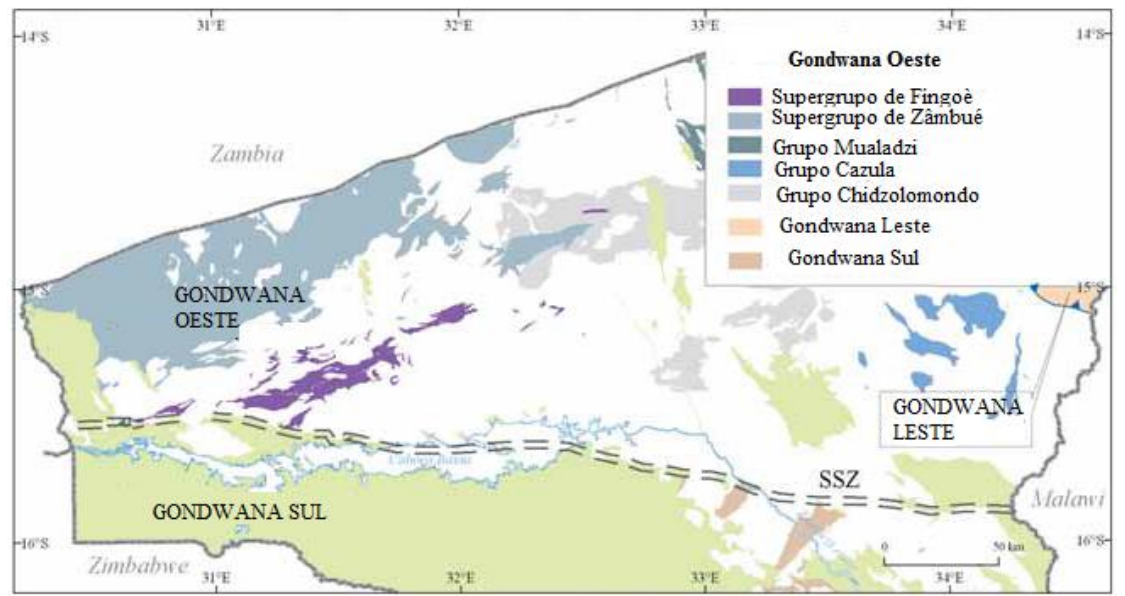

Figura 5- Mapa da província de Tete, NW de Moçambique mostrando as 3 placas litosfericas, e as rochas supracrustais Mesoproterozoicas, (Westerhof, 2008).

\subsubsection{Rochas intrusivas do Mesoproterozoico}

Com base nas características estruturais, composicionais (resultados analíticos e assinaturas aerogeofísicas) e idades, granitóides do Mesoproterozóico no TCB podem ser agrupadas em vários sub-grupos de rochas graníticas e uma suíte bi-modal colocadas durante o ciclo orogênico Grenvilliano (GTK Consortium 2006, Mänttäri et al. 2008). Estes são (do mais antigo ao mais recente): (1) Serra Chiúta (> 1,2 Ga), (2) Rio Capoche ( 1,20 Ga), (3) Rio Tsafuro ( 1,12 Ga), (4) Serra Danvura (> 1,08 Ga), (5) Monte Capirimpica ( 1,09 Ga), (6) Cassacatiza ( 1,08 Ga), (7) Monte Sanja (1,05 Ga), (8) Mussata (fortemente milonitizado, ocasionalmente filonítico; pode ser completamente retrogrado ao granulíto de Chidzolomondo) e (9) granitóides ou suites Furancungo (Fig.6). Esta última compreende a 1,04 Ga do granito Desaranhama. 


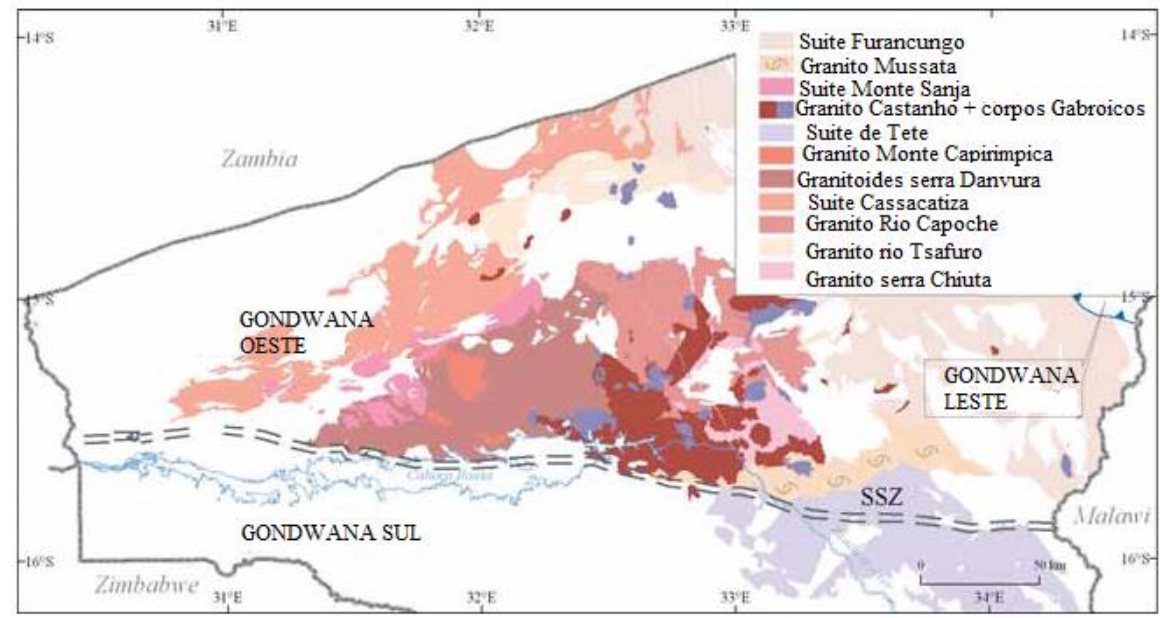

Figura 6 - Distribuição dos granitoides do Mesoproterozoico e suites bi-modais no cinturão de Tete-Chipata norte da Província de Tete (Westerhof, 2008).

\subsubsection{Rochas intrusivas Pan-Africanas}

Na província de Tete, as rochas supracrustais Neoproterozóicas estão ausentes no TCB e apenas uma pequena fração das rochas intrusivas foram colocadas durante o ciclo orogênico PanAfricano (Fig.7). No início do ciclo Pan-Africano rochas intrusivas no TCB incluiam a Suite de rochas félsicas a intermediária de Matunda e as Suites (ultra) máfica de Atchiza e Ualádze na parte oeste da Província de Tete. No final do Fanerozóico, granitoides anteriormente denominado por "suíte Graníticas tardias" (Hunting 1984a,b), são agora atribuídos a Suite Sinda (502 \pm 8 Ma), Macanga (470 \pm 14 Ma), Monte Tarai e Granitos Monte Inchinga (GTK Consortium 2006, Mänttäri et al. 2008). 


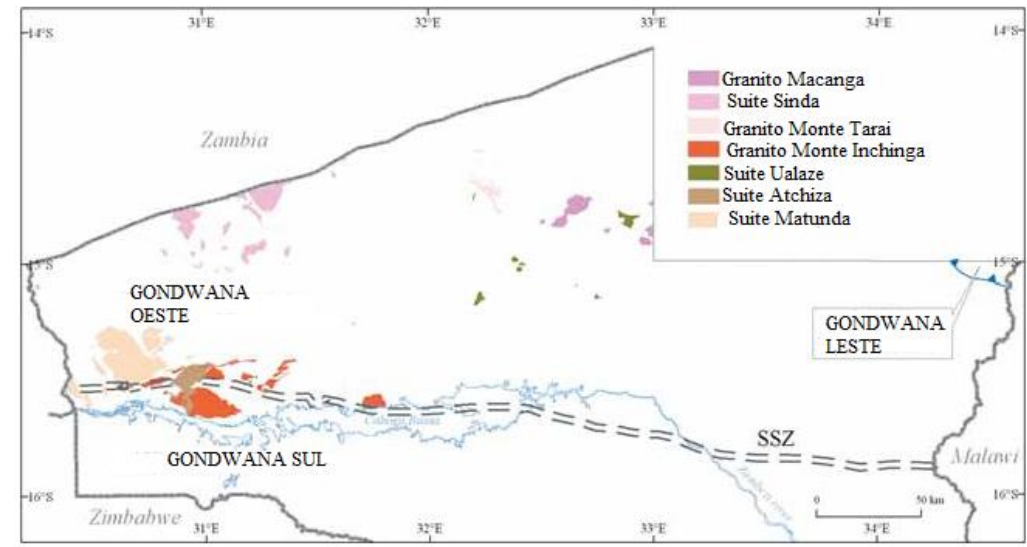

Figura 7- Distribuição Pan -Africana dos granitóides e suites bi-modais do cinturão de Tete-Chipata. Retirada do GTK consortium (2006).

\section{6- Geologia do Cinturão Fíngoè}

O cinturão Fíngoè está localizado à NW da província de Tete (Fig.8), e está inserido na sequência Vulcano-sedimentar pertencente a rochas supracrustais Mesoproterozóicas acima descritas. Esta área abriga uma grande variedade de rochas metassedimentares com quantidades subordinadas de rochas metavulcânicas (GTK consortium; 2006), e consiste de rochas vulcânicas máficas e félsicas de fácies de xistos verdes à anfibolíticas, incluindo rochas piroclásticas, brechas vulcânicas e aglomeradas, e metassedimentos como xisto cálcio-silicato e gnaisse, quartzitos e rochas ferruginosas bandadas. Com base nas evidências de campo, apresentadas pela GTK consortium (2006) as rochas do cinturão de Fíngoè, subdividem-se em dois (2) grupos e quatro (4) formações, como se segue na tabela 2. 
Estudos Petrográficos e Geocronológicos do Prospecto Mankombiti, Cinturão de Fíngoè, Província de Tete Noroeste de Moçambique.

Tabela 2-Descrição lito-estratigráfica das Formações Geológicas na Área de Estudo a partir de informação contida no mapa 1:250.000. (GTK consortium, 2006)

\begin{tabular}{|c|c|c|c|}
\hline GRUPO & FORMAÇÃAO & PRINCIPAL LITOLOGIA & CÓDIGO \\
\hline \multirow{2}{*}{ Monte Tchicombe } & \multirow[t]{2}{*}{ Monte Puéque } & Micaxisto cálcio-silicatados & $\mathrm{P}_{2} \mathrm{FPmc}$ \\
\hline & & Gnaisse cálcio-silicatados & $\mathrm{P}_{2} \mathrm{FPcc}$ \\
\hline \multirow{3}{*}{ Monte Tchicombe } & \multirow{3}{*}{ Rio Mucanba } & Conglomerados Polimicticos & $\mathrm{P}_{2} \mathrm{FMco}$ \\
\hline & & Meta- arenito & $\mathrm{P}_{2} \mathrm{FMss}$ \\
\hline & & Quartzito & $\mathrm{P}_{2} \mathrm{FMqz}$ \\
\hline \multirow[t]{2}{*}{ Monte Tchicombe } & & Marmóres. & $\mathrm{P}_{2} \mathrm{FHm}$ \\
\hline & & Rocha metavulcanica felsica & $\mathrm{P}_{2} \mathrm{FHv}$ \\
\hline \multirow{4}{*}{ Monte Messuco } & \multirow{4}{*}{ Monte Muinga } & Aglomerados e Brecha vulcânica & $\mathrm{P}_{2} \mathrm{FGb}$ \\
\hline & & Rochas amigdaloides máficas e metavulcânica félsica. & $\mathrm{P}_{2} \mathrm{FGmf}$ \\
\hline & & Rocha metavulcanica Mafica a intermédia & $\mathrm{P}_{2} \mathrm{FGvi}$ \\
\hline & & Rochas metavulcânicas félsicas. & $\mathrm{P}_{2}$ FGfi \\
\hline \multirow[t]{2}{*}{ Monte Messuco } & & Micaxistos & $\mathrm{P}_{2} \mathrm{FSch}$ \\
\hline & & Mármore & $\mathrm{P}_{2} \mathrm{FSm}$ \\
\hline \multirow{4}{*}{ Monte Messuco } & \multirow{4}{*}{ Monte Rupanjaze } & Metacherts & $\mathrm{P}_{2} \mathrm{FRch}$ \\
\hline & & Rochas piroclasticlas máficas e micaxixtos & $\mathrm{P}_{2} \mathrm{FRvf}$ \\
\hline & & Formações ferruginosas bandadas & $\mathrm{P}_{2}$ FRvfe \\
\hline & & Rocha metavulcanica Máfica e ultramáfica & $\mathrm{P}_{2} \mathrm{FRvm}$ \\
\hline
\end{tabular}

A descrição detalhada da tabela 2 em conformidade com a GTK consortium (2006) é apresentada a seguir da base ao topo.

\subsection{1- Grupo Monte Messuco}

\subsubsection{Formação Monte Rupanjaze}

\section{Rochas metavulcânicas máficas e ultramáficas $\left(P_{2}\right.$ FRvm)}

As rochas metavulcânica máficas e ultramáficas são comumente encontradas na parte central do cinturão Fíngoè, onde ocorrem associadas a mármores, rochas metassedimentares e 
metavulcanitos piroclásticos. Bandas verdes escuras, e anfibólio de grão fino estão dispersos nestas rochas. Os metavulcanitos máficos são compostos por proporções iguais de plagioclásio e hornblenda, com poucas quantidades de quartzo, epidoto, biotita e minerais opacos.

\section{Formação ferruginosa bandada $\left(P_{2} F R v f e\right)$}

A formação ferruginosa bandada, encontra-se associada a rochas metavulcânicas máficas e intermédias, do monte Rupanjaze. Apresentam cores cinza rosado, cinza amarelado e minerais opacos com bandas de 1-15 cm de largura, formando bandas alternadas e lâminas na rocha. As bandas são localmente dobradas.

\section{Rochas piroclásticas máficas e micaxistos $\left(P_{2} F R v f\right)$}

As rochas piroclásticas máficas e micaxistos são parte da sequência Vulcano-sedimentar, composta principalmente de rochas metavulcânicas máficas e rochas metassedimentares. Estas rochas ocupam a parte central da sucessão Fíngoè.

\section{Metacherts $\left(\boldsymbol{P}_{2}\right.$ FRch $)$}

Metacherts são rochas quartzíticas de grão médio a fino. Compreendem epidoto e diopsídio. A coloração é geralmente cinza, mas localmente as rochas são esverdeadas ou pouco azuladas, com pouca variação composicional.

\section{Mármores e rocha carbonática impura $\left(\boldsymbol{P}_{2} \mathrm{FSm}\right)$}

Os mármores e rocha carbonática impura estão associados ao grupo do Monte Messuco. São expostos entre o rio Muze e o rio Mucanha. A sequência de mármore é dominada por metassedimentos calcários com intercalações diversas e grossas de cálcio-silicatos e chert, invadidos por plagioclásio pórfiro e diques doleríticos.

\section{Micaxistos $\left(\boldsymbol{P}_{2}\right.$ FSch $)$}

Os Micaxistos ocorrem comumente na parte oeste e central de Fíngoè. Petrologicamente eles variam de filito à micaxisto. São geralmente muito alterados, de coloração escura a cinza escura, de grão médio, tornando-se grosseiros na parte oeste, comparado com a parte central do cinturão Fíngoè. 


\subsubsection{2- Formação Monte Muinga.}

\section{Rocha metavulcânica félsica $\left(P_{2}\right.$ FGfi)}

As Rochas metavulcânicas félsicas são de grão fino com poucas intercalações de metavulcânicas máficas e vulcanoclásticas. Os metassedimentos silicificados formam uma sequência vulcanosedimentar heterogênea, na parte acima da formação do Monte Muinga.

\section{Rocha metavulcânica máfica a intermédia $\left(P_{2} F G v i\right)$}

As Rochas metavulcânicas máficas a intermédias estão expostas ao longo da margem norte do cinturão Fíngoè. Estas são variadamente bandadas por epidoto e anfibólio. Estruturas vulcânicas primárias estão ausentes devido a forte deformação. Localmente, os metavulcanitos podem também conter porfiroblástos de granada, particularmente em afloramentos situados nos granitos de Cassacatiza.

\section{Rochas amigdaloides máficas e metavulcânica félsica $\left(P_{2} F G m f\right)$.}

As Rochas amigdaloides máficas e metavulcânica félsica ocorrem dentro da sucessão de metavulcânicas da Formação Monte Muinga. Elas estão expostas perto de rochas carbonáticas do Grupo do Monte Messuco. Metabasaltos semelhantes também foram encontrados como grandes xenólitos dentro dos granitoides que cercam o cinturão Fíngoè.

\section{Aglomerados e Brecha vulcânica $\left(P_{2} F G b\right)$}

Os Aglomerados e Brecha vulcânica formam horizontes relativamente finos, mas contínuos de rochas clásticas grossas, supostamente representando aglomerados, brechas vulcânicas e conglomerados polimíticas de afinidade vulcânicas. Ocorrem entre a sequência metavulcânica do cinturão Fíngoè. O material clástico do conglomerado, varia de veio de quartzo puro e quartzito para rochas metavulcânicas intermediárias e félsicas, mas também rochas metavulcânicas máficas, ultramáficas e granito de grão médio são observadas. 


\subsection{2-Grupo do Monte Tchicombe}

\section{Rocha metavulcânica félsica $\left(\mathrm{P}_{2} \mathrm{FHv}\right)$}

Os metavulcanitos félsicos ocorrem dentro do Grupo Monte Tchicombe. A presença de cristais de Fe-Mg-silicato nestas rochas fracamente laminadas sugere uma origem tufítica. A componente principal é o quartzo, rocha com pouco feldspato, biotita, piroxênio e anfibólio. Devido à intensa deformação, as rochas se assemelham localmente a xistos quartzo-feldspato, que, no entanto, são tipicamente mais félsicas na cor.

\section{Mármore e rocha carbonática impura $\left(\mathrm{P}_{2} \mathrm{FHm}\right)$}

Os mármores e rocha carbonática impura, ocorrem em muitas partes do cinturão Fíngoè. Mármores com intercalações de cálcio-silicato do Grupo Monte Tchicombe, estão expostos em horizontes longos ao longo do leste do Monte Tchicombe. Afloramentos de rochas carbonáticas puras são normalmente, colinas arredondadas ou planas, e não formam cumes como na região do Messeca cerca de $25 \mathrm{~km}$ a oeste. Cerca de $3 \mathrm{~km}$ a leste de Monte Tchicombe, camadas e horizontes concordantes de mármore, são comuns e podem alcançar uma largura de dezenas de metros. Vários gnaisses cálcio-silicato ocorrem como intercalações estreitas nos horizontes carbonáticos.

\subsubsection{1- Formação Rio Mucanba}

\section{Quartzitos ( $\left.\boldsymbol{P}_{2} \mathrm{FMqz}\right)$}

A maioria dos horizontes de quartzitos ocorrem como finas intercalações dentro de xisto predominantemente pelíticos, do grupo Monte Messuco. Eles raramente são grossos o suficiente para formar colinas ou sulcos. Intercalações quartzíticas finas também têm sido encontradas cortando o conglomerado polimíctico do Monte Mucanba. 


\section{Meta-arenito e xisto quartzo-feldspatico ( $\left.P_{2} F M s s\right)$}

Os meta- arenitos são fracamente bandados e ocorrem em terrenos baixos do cinturão Fíngoè como variadas intercalações finas de gnaisses cálcio-silicato da Formação Mucanba. Texturalmente, os meta-arenitos podem variar de castanho avermelhado, para variedades de xistos quartzo-feldspáticos e rochas graníticas recristalizadas. Estreitos veios de granitos leucocráticos são comumente encontrados.

\section{Conglomerados Polimícticos $\left(\boldsymbol{P}_{2}\right.$ FMco)}

Um corpo conglomerado polimíctico proeminente, é exposto ao longo do Rio Mucanha na região central do cinturão Fíngoè, provavelmente representando um conglomerado intra-formacional. A matriz cinza esverdeada escura do conglomerado é composta de grãos angulares de quartzo, feldspato alcalino e plagioclásio em uma massa de grão fino de quartzo, feldspato, epidoto, biotita e hornblenda.

\subsubsection{2 - Formação do Monte Puéque}

\section{Gnaisse cálcio-silicatados e micaxistos cálcio-silicatados $\left(P_{2}\right.$ FPcc e $P_{2}$ FPmc $)$}

Os gnaisses cálcio-silicatados esverdeados e com tons acinzentados são tipicamente encontrados em superfícies mais frescas. Estes são compostos por plagioclásio, quartzo e epidoto. A mica ocorre apenas como um mineral acessório. Intensamente foliados, os micaxistos cálcio-silicato são encontrados perto do cume do Monte Tchicombe. Estes xistos têm relações estreitas com os gnaisses cálcio-silicatados e metavulcânicas ricas em cálcio. Minerais dominantes nos micaxistos cálcio-silicatados são micas brancas (até $20 \%$ em volume) de granulação fina a muito fina, plagioclásio, quartzo, calcita e epidoto. 


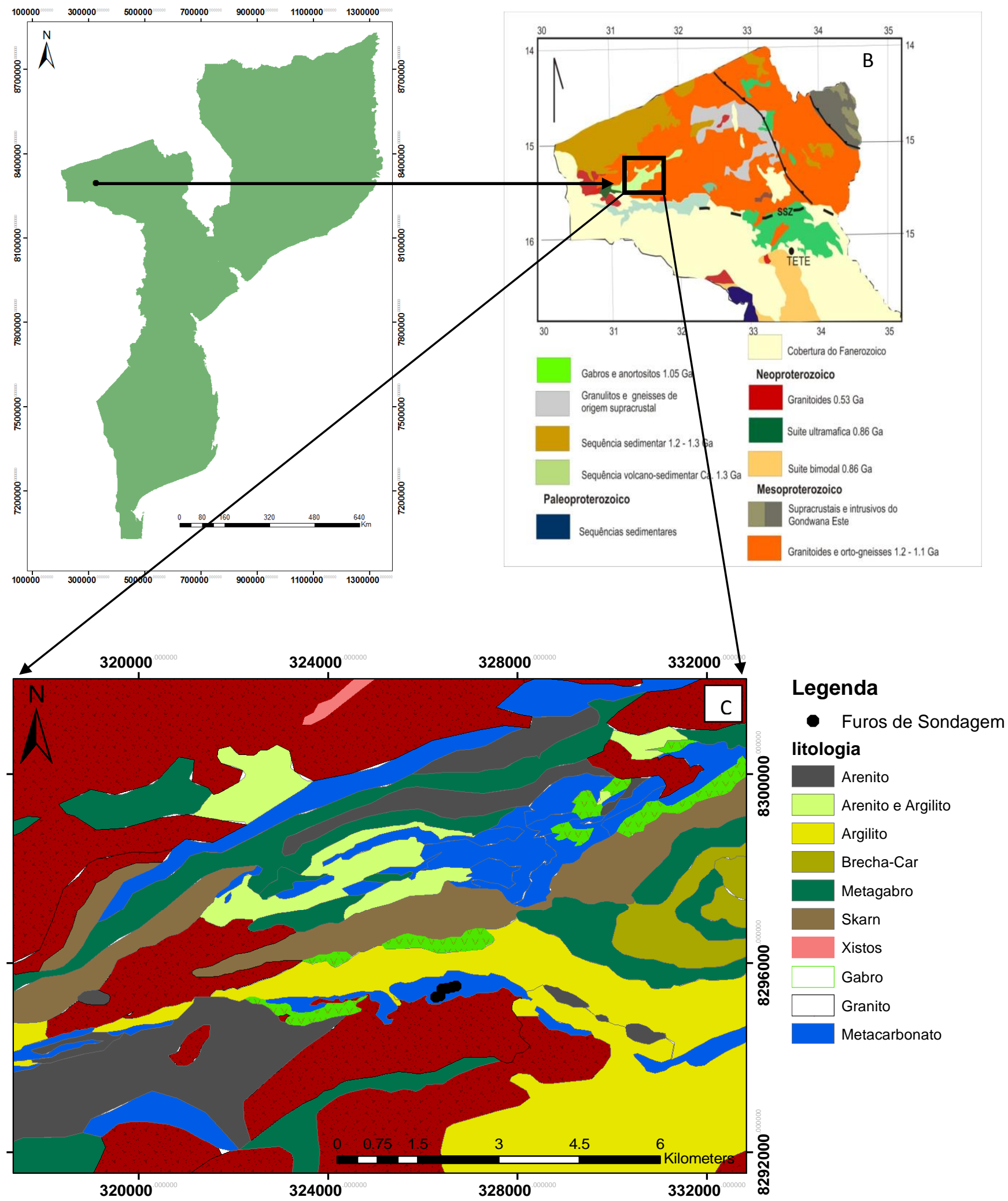

Figura 8- B: Mapa geológico de Tete; C: Mapa detalhado do cinturão Fíngoè, com a localização dos furos de sondagem, marcada por pontos pretos. 


\section{7- Síntese de Dados Geocronológicos da província de Tete}

Poucos são os trabalhos geológicos e mapeamentos desenvolvidos na província de Tete. Destes destacam-se os trabalhos realizados pela GTK Consortium. Estes trabalhos estão relacionados com o mapeamento geológico de Moçambique na escala 1:250.000 correspondente ao Projeto de Capacitação em Gestão dos Recursos Minerais (MRMP) em conjuto com a equipe técnica da Direção Nacional de Geologia (DNG), financiado pelo Fundo de Desenvolvimento Nórdico (NDF) entre os anos de 2002 a 2006. Outro resultado dos trabalhos foi a produção de um mapa geológico na escala de 1:1.000.000.

O trabalho mais recente foi levado a cabo por Mänttäri (2008), que apresentou uma tentativa de evolução tectônica através de idades radiométricas a NW de Moçambique cobrindo as províncias de Tete, Manica e Sofala.

Neste trabalho dá-se mais ênfase amostras datadas na província de Tete, onde se localiza a área de estudo. O resultado dos dados geocronológicos das amostras concentradas na parte Norte da área de interesse está apresentado na tabela 3.

Tabela 3- Síntese de dados geocronológicos U/Pb em Zircão e $\mathrm{Sm} / \mathrm{Nd}$ de rochas Mesoproterozóicas e Neoproterozoicas no NW de Moçambique-Província de Tete Mänttäri (2008).

\begin{tabular}{|l|l|l|l|}
\hline Rocha/número de campo & Suite/Complexo & Método & Idade (Ma) \\
\hline Granito gnaisse (Mos-1) & Rio Capoche & U/Pb SHRIMP & $1201 \pm 10$ \\
\hline Granito Monte Dombe (Mos-2) & \multirow{2}{*}{ Cassacatiza } & U/Pb TIMS & $\sim 1.1 \mathrm{Ga}$ \\
\cline { 3 - 4 } Granito (Mos-9) & & U/Pb TIMS & $1077 \pm 2$ \\
\cline { 3 - 4 } Granito (Mos-15) & Macanga & U/Pb SHRIMP & $470 \pm 14$ \\
\hline Granito (Mos-8) & Monte Sanja & U/Pb TIMS & $1050 \pm 8$ \\
\hline Granito (Mos-10) & Furancungo & U/Pb TIMS & $1041 \pm 4$ \\
\hline Granito Desaranhama (Mos-11) & Sinda & U/Pb SHRIMP & $502 \pm 8$ \\
\hline Granito (Mos-12) & Granito Castanho & U/Pb TIMS & $1050 \pm 2$ \\
\hline Granito (Mos-13) & Matunda & U/Pb SHRIMP & $784 \pm 36$ \\
\hline Granito gnaisse (Mos-16) & Monte Capirimpica & U/Pb TIMS & $1086 \pm 7$ \\
\hline Granito (Mos-18) & Supergrupo Fíngoè & U/Pb SHRIMP & $1327 \pm 16$ \\
\hline Metavulcânica félsica/intermédia (Mos-34) & Atchiza & Sm/Nd isócrona mineral & $864 \pm 30$ \\
\hline Gabro (Mos-14) & Chipera & Sm/Nd isócrona mineral & $1047 \pm 29$ \\
\hline Gabro (Mos-17) & & \\
\hline
\end{tabular}



Noroeste de Moçambique.

As rochas supracrustais Mesoproterozóicas ocupam grandes áreas na província de Tete principalmente acima da zona cisalhamento Sanângoè e são intrudidos por corpos granitos do Neoproterozoico, como é mostrado no mapa da Fig. 9.

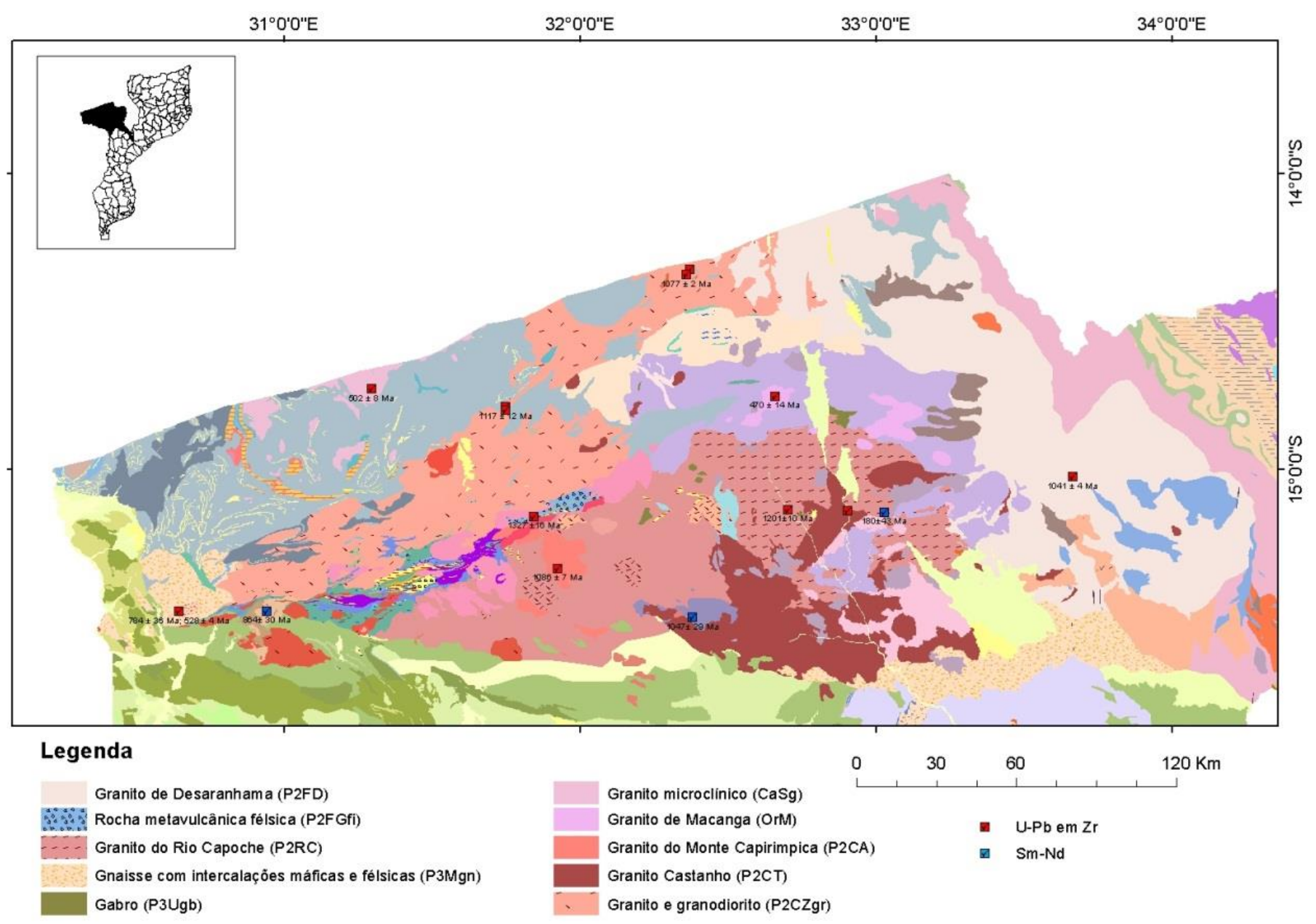

Figura 9 -Mapa com dados geocronológicos da provincia de Tete 


\section{8 - Aspectos Geológicos da Área de Estudo.}

\section{Alvo Mankombiti}

A área do prospecto Mankombiti (Fig.10) constitui o objeto de estudo para este trabalho, e é parte do cinturão Fíngoè, localizado na porção oeste. É coberto por metacarbonatos, metassedimentos arenosos, e metassedimentos argilosos intrudidos ao sul pelo granito e granito com epidoto- magnetita. O metagabro invade as rochas metacarbonáticas na parte Leste do alvo. O mármore dolomítico forma um cume proeminente E-W com mergulhos íngremes para o norte. As foliações são quase E-W com mergulhos 58-66 N. Segundo Christopher, (2010) a Mineralização de magnetita-malaquita ocorre perto do contato entre o granito e o mármore.

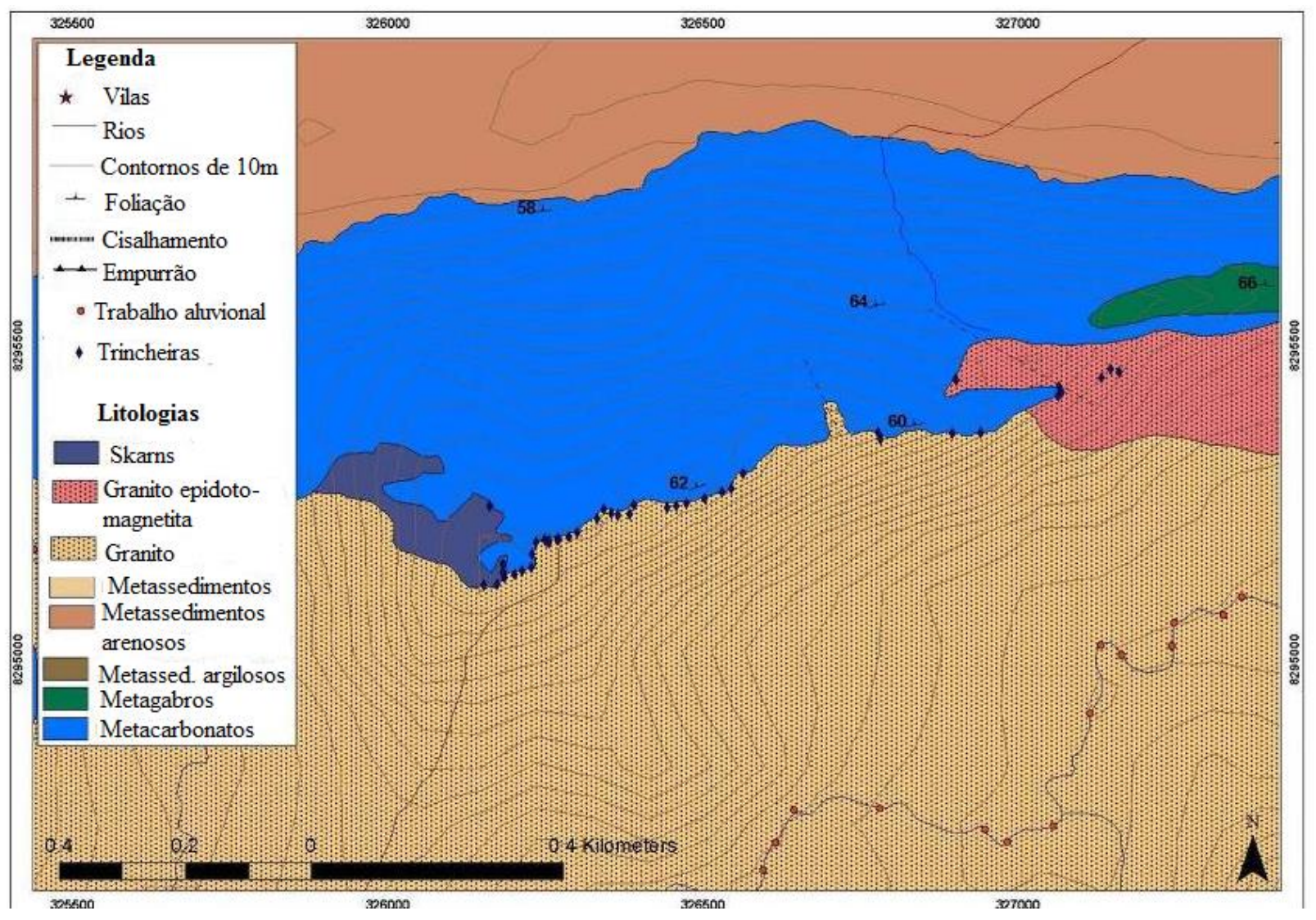

Figura 10 - Mapa geológico do alvo Mankombiti (Christopher, P.A.; 2010). 


\section{INTERPRETAÇÃO E DISCUSSÃO DOS RESULTADOS}

\section{1- Caracteristicas Petrográficas e Mineralográficas do Mankombiti}

\subsection{1-Petrografia}

Os estudos petrográficos foram efetuados a partir de um total de 15 seções delgadas, extraídas de furos de sondagem e têm como finalidade a descrição das amostras cedidas para esta pesquisa. Estas amostras pertencem à formação do Monte Muinga, acima descrita. As informações, provenientes desse procedimento tratam sobre a composição mineralógica, tipo de alteração hidrotermal que afetou as diferentes litologias. Além disto, a partir dos critérios texturais e mineralógicos foram caracterizados os tipos de alteração que afetou cada unidade.

\subsection{2-Unidades de mármores e Brechas do Monte Muinga}

Os mármores são de cor cinza esbranquiçada, apresentam cristais com tamanhos que variam entre 2-3 mm de calcita e dolomita imbricadas entre si, com clivagem romboédrica, com alta birrefringência associada à dolomita, contém quartzo em pequenas quantidades e algumas inclusões de anfibólio. Apresentam uma textura granoblástica poligonizada (Fig.11 A e B)

As brechas são encontradas entre a sequência metavulcânica do cinturão de Fíngoè (GTK Consortium, 2006). São constituídas por clastos subarredondados de composição variada, envolvidos em uma matriz micro-criptocristalina. Estas rochas geralmente apresentam uma cor cinza esverdeada. A textura é brechosa, a matriz é por vezes suportada por clástos. Apresentam vênulas posteriores ao cimento. A deformação intensiva dos clástos dificulta a determinação da natureza e composição primária dessas rochas. Em lâmina delgada observa-se que o cimento destas rochas é composto por actinolita + Tremolita + clorita + epidoto \pm moscovita. Quando a granulação é mais grossa, textura holocristalina, é possível observarem-se cristais de anfibólio, feldspato alcalino albitizados, e cristais de piroxênio (Piogenita) (Fig.11D). Quando a matriz é muito fina, textura micro-criptocristalina, verifica-se uma grande quantidade de minerais opacos 
em forma de bolsões, (Fig. 11C). A estimativa porcentual destas rochas torna-se difícil, pelo facto delas formarem sempre agregados muito finos.

Os minerais de alteração encontrados são a calcita + clorita + epidoto. Na amostra MW05/001P, a carbonatização é muito expressiva. Os cristais de carbonato estão em contato com os minerais opacos por vezes são invadidos por minerais como a titanita. Por vezes a carbonatação ocorre no estilo fissural pervasivo, (Fig. 11c) juntamente com a clorita cortando os opacos. O estilo fissural caracteriza-se pelo preenchimento de fraturas de forma irregular por carbonato.

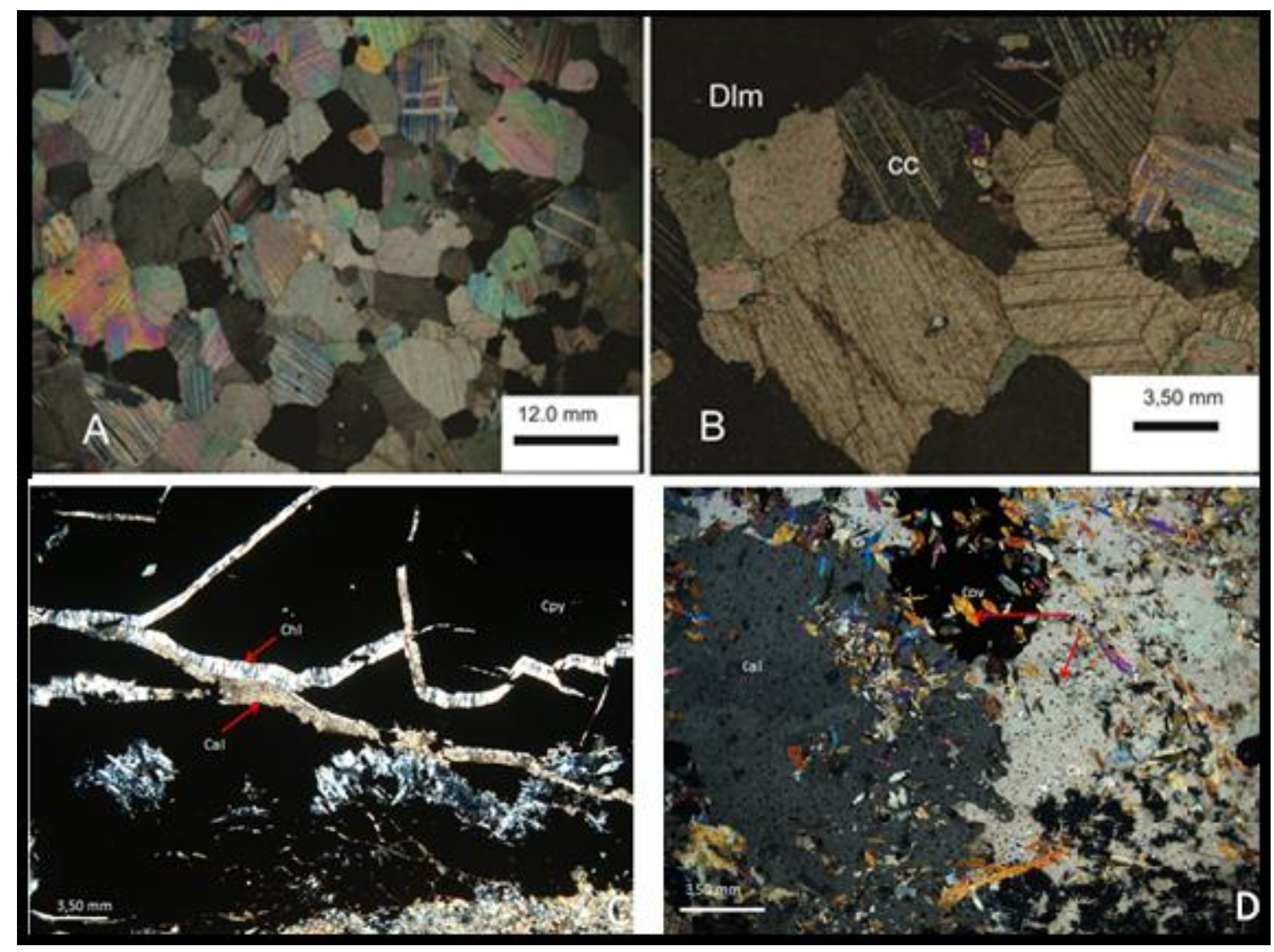

Figura 11 - A. Textura granoblástica poligonizada nos mármores; B) Ilustração dos minerais de calcita (cc) e dolomita (Dlm) nas amostras de mármore;.C) brecha mostrando matriz fina, maciço, carbonatação fissural (Cal); D) orientação dos cristais da matriz carbonatica, mostrando alguns clastos de Piogenita (piog).

\subsubsection{Unidade de Granitos do Monte Muinga}

São rochas maciças holocristalinas de textura granular a inequigranular, de grão médio a grosseiro, apresentam uma cor rosa. A assembleia mineral é dominada por plagioclásio, 
microclinio e piroxênio, o mineral acessório comumente encontrado é a titanita magmática. Os fenocristais de plagioclásio (20-30\%) são euédricos a subeuédricos, com habito tabular. É notória a geminação da lei de albita. O feldspato alcalino (20-40\%) ocorre como cristais anédricos geminados segundo as leis de carlsbad e albita (Fig.12A e C), esta última superposta à Carlsbad. Alguns se apresentam pertíticos. Os cristais de piroxênio (10-15\%) mostram um habito prismático, e são euédricos, bem cristalizados (Fig.12B), com tamanhos que variam de 1 a $3 \mathrm{~mm}$. Em algumas partes dos litotipos ocorrem como pórfiros e estão sendo substituídos por epidoto bem na fase inicial. Os cristais de anfibólios (5-10\%) são euédricos com um habito prismático estão parcial ou totalmente substituídos por epidoto, em alguns casos são notáveis os cristais de anfibólio bem no inicio da alteração em epidoto (Fig. 12D). O quartzo ocorre em cristais anédricos e com contatos irregulares e apresenta extinção ondulante. É encontrado em forma de agregados.

A alteração hidrotermal nestas rochas é dada pela substituição do plagioclásio por clorita+ sericita + epidoto. O tipo de alteração é propílitica. A alteração propilítica é caracterizada pela adição de $\mathrm{H}_{2} \mathrm{O}$ e $\mathrm{CO}_{2}$, e $\mathrm{S}$ localmente, sem metassomatismo considerável de $\mathrm{H}^{+}$. A Zeolita neste tipo de alteração é indicativa de temperatura, pressão e profundidade (Pirajno, 2009). O feldspato alcalino é geralmente substituído por sericita. A matriz apresenta saussuritização de plagioclásio, esta alteração apresenta-se de forma seletivamente pervasiva e é possível observar também a cloritização do clinopiroxênio e anfibólio bem como a alteração não seletiva, mas do tipo fissural do carbonato e por vezes epidoto. 


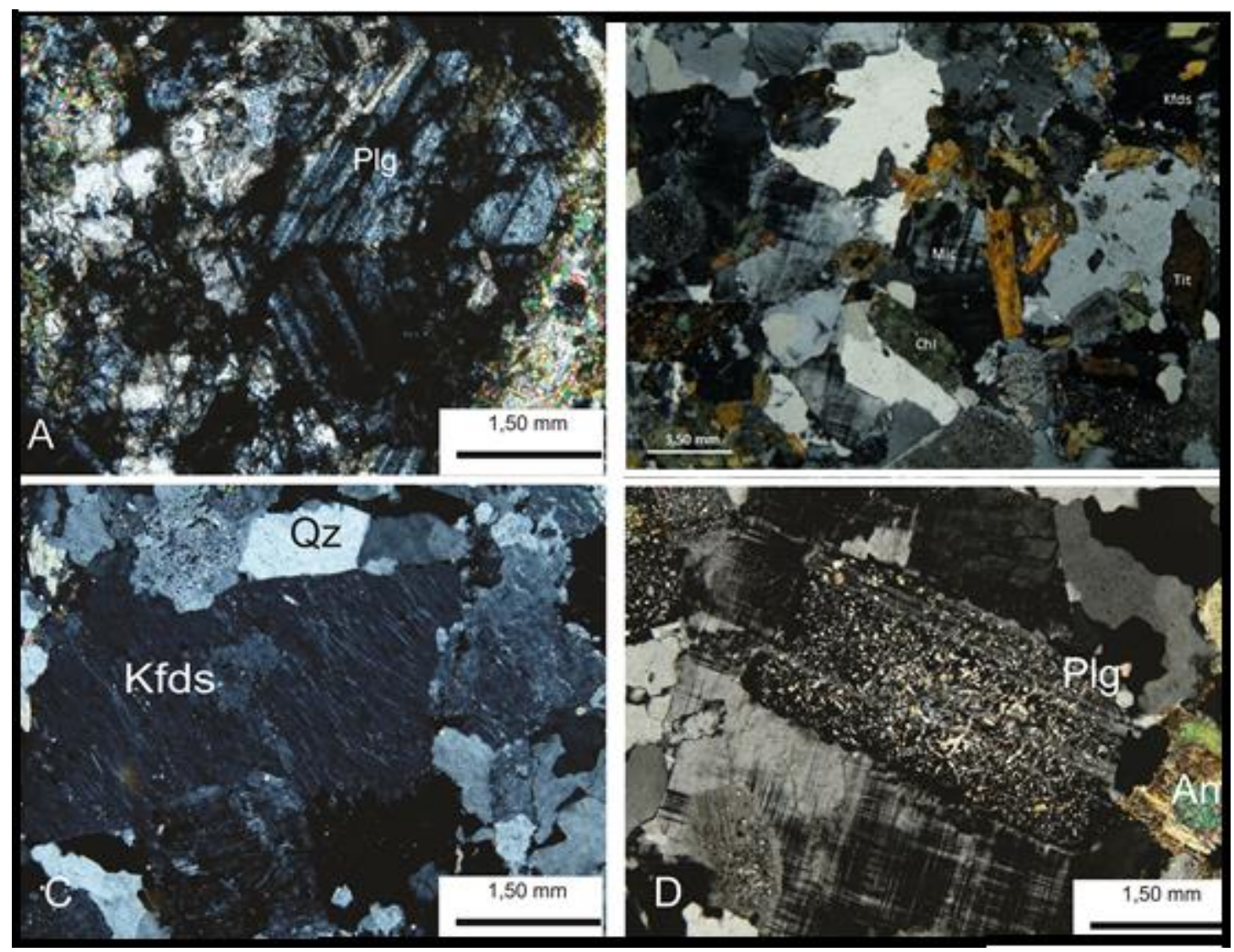

Figura 12- A) cristais zonados de plagioclásio (Plg); B) alteração seletivamente pervasiva da clorita (chl) cristais de titanita (Tit) magmática e Microclinio (Mic); C) feldspato alcalino (Kdfs) com lamelas de exsolução; D) saussuritização de Plagioclásio no estilo seletivamente pervasiva, e cristas de anfibólio sendo alterado nas bordas e no núcleo, por epidoto.

\subsection{3- Unidade dos gabros do Monte Muinga}

As rochas desta unidade são comumente encontradas na parte central do Cinturão Fíngoè, onde são intrusivas nos mármores, rochas metassedimentares clásticas e metavulcânicas piroclásticas. Apresentam cores variando de cinza esbranquiçada à cinza esverdeada. Estes gabros apresentam pequenos cristais de sulfeto disseminados na matriz. Pequenas vênulas escuras são notórias em algumas das amostras. Estratigraficamente elas estão localizadas na parte inferior da sequência supracrustal (GTK Consortium, 2006). Estas rochas apresentam-se maciças de grão fino, com textura inequigranular a glomeroporfirítica, e com fenocristais de clinopiroxênios e anfibólios euédricos que variam de forma geral de $1-5 \mathrm{~mm}$ em algumas amostras. A matriz microlítica, 
contém plagioclásio e pseudomorfos de minerais máficos obliterados em clorita e / ou epidoto. A apatita, a titanita e os minerais opacos (possivelmente a magnetita) são os principais minerais acessórios. Algumas amostras apresentam variações de granulometria, com fenocristais mais finos (amostras ME06/001P) e outras com cristais de plagioclásio preservados que não seguem uma orientação preferencial evidenciada pelos de cristais de clorita (amostra ME05/002P).

Os fenocristais de clinopiroxênios representam um total entre 20 - $40 \%$ mostram-se como grãos euédricos a subeuédricos de habito prismático e com feições de arredondamento. Apresentam pleocroísmo fraco (verde-verde claro). As bordas destes cristais são retilíneas, mas por vezes apresentam feições de corrosão e/ou substituição completa do mineral (Fig. 13A).

Os fenocristais de anfibólio (10-15\%) constituem a fase mais fina, com contatos irregulares exibindo um pleocroísmo de verde escuro a castanho (Fig. 13B). A característica que este mineral apresenta é a substituição que se manifesta nas bordas, nos núcleos dos grãos, mas que chegam por vezes a obliterar cristais inteiros.

Subordinado a isto, cristais de plagioclásio (10 - 30\%) são encontrados (Fig. 13C). Estes são de granulação fina a média e habito tabular, ocorrem na matriz e obedece à lei albita-carlsbad, nos poucos cristais que são possíveis de observar nota-se ausência de deformação como formação de outro grão ou quebramento, o que pode indicar que estes plagioclásios tenham sido gerados no magma inicial. Apresentam uma substituição incipiente para sericita, e em suas bordas ocasionalmente o quartzo pode ser encontrado.

A substituição dos minerais primários nestas rochas varia de incipiente e seletivamente pervasiva a intensa e pervasiva. A principal assembleia mineral é composta por de clorita + epidoto + carbonato + sericita + quartzo \pm prenhita, podendo-se concluir que estes gabros foram afetados por uma alteração do tipo propilítica. A substituição do clinopiroxênio (Fig. 13D) é mostrada pelo aparecimento de clorita, epidoto e opacos (produto de alteração) e o plagioclásio apresenta a saussuritização. Em algumas amostras os estágios de alteração são mais intensos e os cristais são completamente substituídos formando pseudomorfos de actinolita, clorita e epidoto. A matriz das rochas apresenta uma leve sericitização, observada em alguns cristais finos de plagioclásio, associadas principalmente com carbonatos, clorita, biotita? e epidoto. A substituição seletiva é mostrada pela obliteração do clinopiroxênio em actinolita em contato com a clorita, carbonato e 
por vezes com minerais opacos. A substituição pervasiva ocorre apenas em algumas rochas. Deste modo as características originais do protólito são alteradas por um conjunto de minerais composto por: epidoto (aparece em forma de cristais anédricos a subeuédricos, com pleocroísmo verde-amarelo, de tamanho variando de 2-3 mm); actinolita (com pleocroísmo forte); clorita (que por vezes está presente na matriz destas rochas, e preenche espaços entre os cristais), opacos e carbonatos (sem habito, e por vezes ocorrem em forma de fissuras), prehnita (que é encontra na amostra MW02/011P provavelmente como produto de alteração da olivina) e quartzo (se apresenta como interstícios, por vezes imbricados entre si, com extinção ondulante), é comum encontrarem-se veios de quartzo caracterizando também este tipo de alteração. 

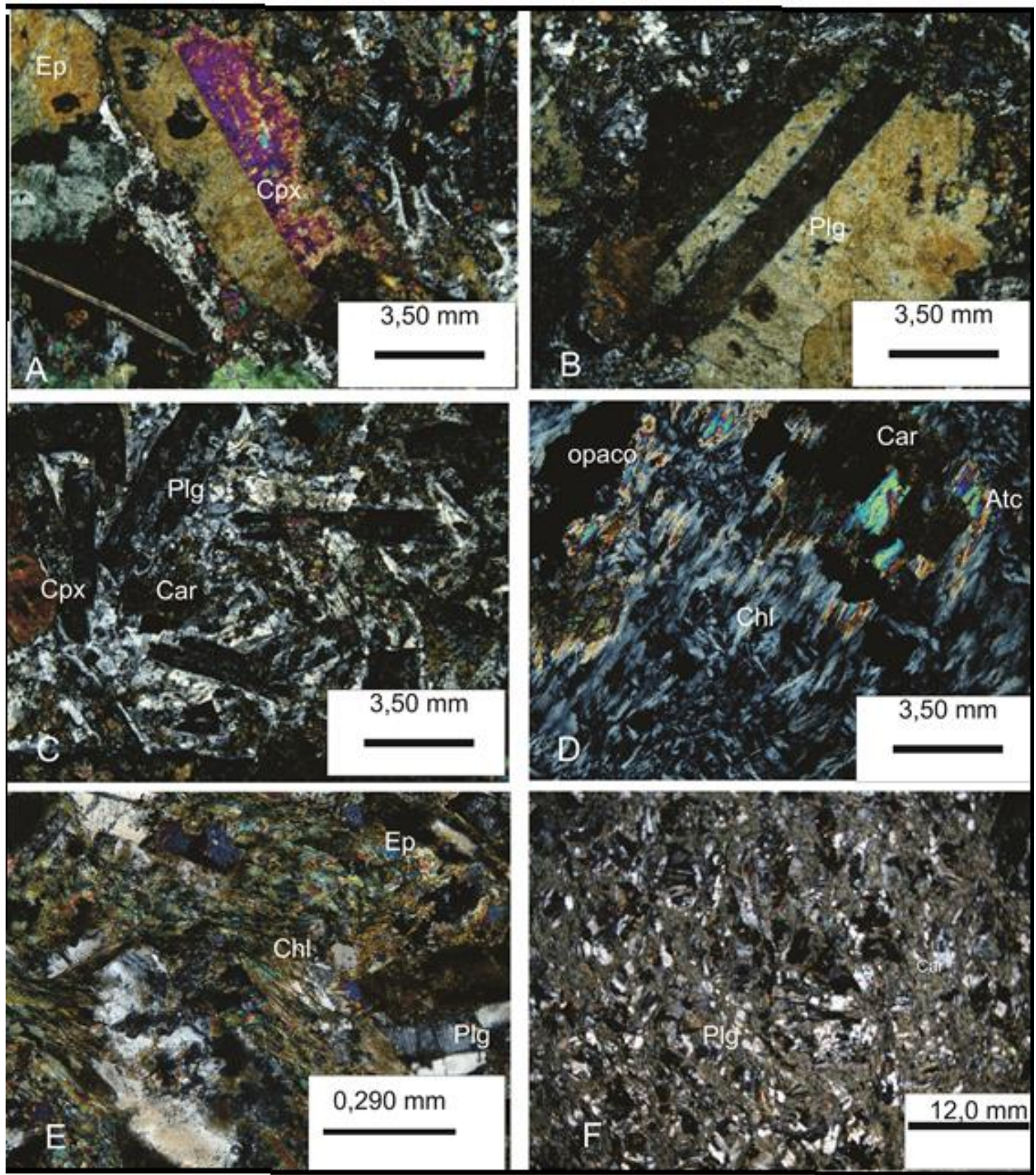

Figura 13- A) cristal de clinopiroxênio (cpx) sendo obliterado nas bordas por epidoto e cristal de epidoto resultante da alteração do clinopiroxênio; B e C) megacristal de plagioclásio e clinopiroxênio em matriz fina; com predomínio de plagioclásio. D) cristais de carbonato (Car), actinolita (Atc), opacos, com orientação dada pelos cristais de clorita (Chl) e alteração seletivamente pervasiva dada pelos mesmos minerais; E) megacristais de plagioclásio (Plg) em uma matriz cloritica sem orientação preferencial; F) aspecto da matriz subofitica, com plagioclásio englobado por minerais máficos alterados para clorita. 


\section{2- Caracterização Mineralógica do Minério}

Segundo Christopher (2010), o prospecto Mankombiti, tem substituição por carbonato ou afinidades tipo skarn com a mineralização constituída de ouro, prata, cobre e zinco (+/- chumbo) com a magnetita associada e valores elevados de bismuto.

O prospecto Mankombiti, tem presença forte de magnetita e zona de carbonato de cobre próximo ao contato de granito com metacarbonáticas. A Malaquita é abundante seguido dos minerais de cobre como a covelita $(\mathrm{CuS})$ e calcocita $\left(\mathrm{Cu}_{2} \mathrm{~S}\right)$, e são sugeridos por causa da forte presença de cobre obtidos a partir de ensaios efetuados na zona de contato. Anomalias pedo-geoquímicas de zinco e chumbo ocorrem dentro das metacarbonáticas e sugerem à presença de substituição da mineralização de galena e esfarelita (chumbo comum e os minerais de zinco, respectivamente) (Christopher, 2010).

Duas amostras foram selecionadas para o estudo detalhado do minério e confirmação das associações minerais por microscopia eletrônica de varredura (MEV). Em alguns locais a observação foi mais cuidadosa, de tal modo que foi possível encontrar o ouro e prata em muito poucas quantidades, associadas aos veios de quartzo.

Nas rochas metassedimentares a mineralização apresenta-se de forma disseminada e é composta de sulfetos de granulação variando de 0.1 a $1,0 \mathrm{~cm}$, compostos essencialmente de calcopirita e bornita (Fig. 14). Na amostra MW05/001P a bornita ocorre com habito laminar em bandas alternadas com a calcopirita. 


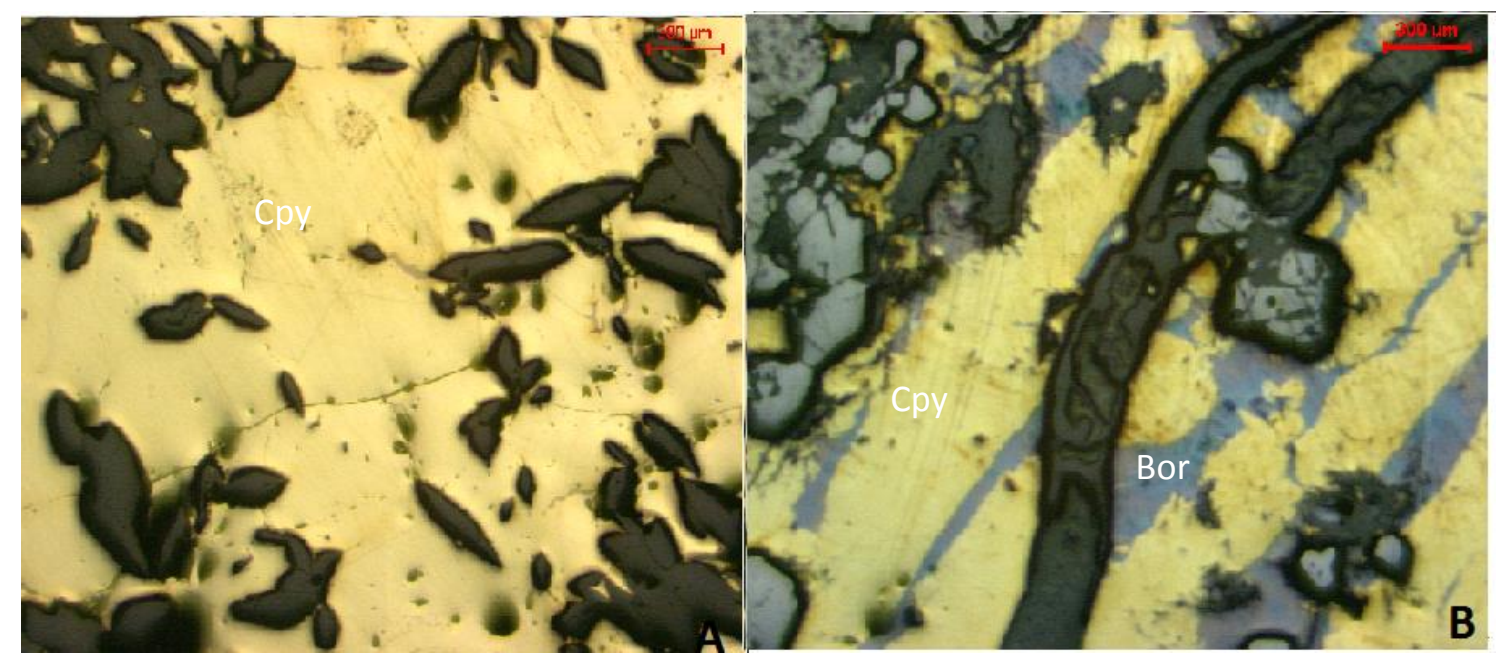

Figura 14 - Microfotografia de minério disseminado na rocha. A) amostra MW03/017P B) MW05/001P

A calcopirita apresenta cristais subidioblásticos entre 20 a $100 \mu \mathrm{m}$, isolados e preenchendo interstícios entre minerais adjacentes, formando agregados de até $1 \mathrm{~cm}$ de comprimento. São notórias pequenas texturas de exsolução associadas com a bornita. A bornita encontra-se diferenciada em dois tipos. A bornita I ocorre como exsolução no meio a uma massa maciça de calcopirita (Fig.15) A bornita II apresenta-se com um habito idiomórfico, os cristais ocorrem como agregados tabulares com inclusões de covelita, e apresentam com uma cor violeta, exibindo uma fraca anisotropia, (Fig.15). 


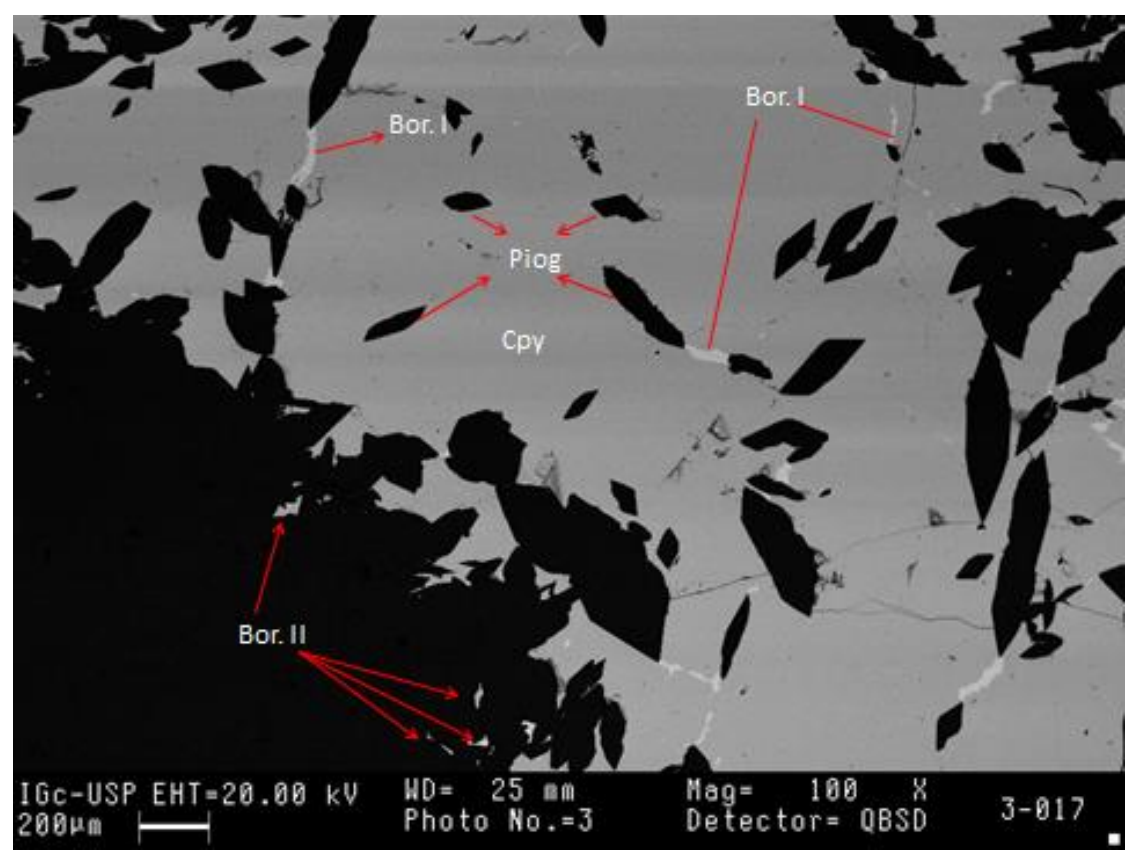

Figura 15- Imagem de Microscopia Eletrônica de Varredura, calcopirita (Cpy), e Bornita (Bor) em forma de exsolução transversal a calcopirita e bornita na ganga associada à covelita. Minerais prismáticos de Piogenita (piog), em meio a uma estrutura maciça de calcopirita.

Associado a mineralização se encontra a Piogenita, a qual se caracteriza pelo seu habito prismático. Geralmente a Piogenita é observada inclusa na calcopirita. Uma análise cuidadosa foi feita no contato entre os grãos da piogenita, pois em alguns deles é notório a presença de cinza mais claro, e o resultado do EDS (em anexo II) foi possivel notar a presença da galena associada a bornita (Fig.16).

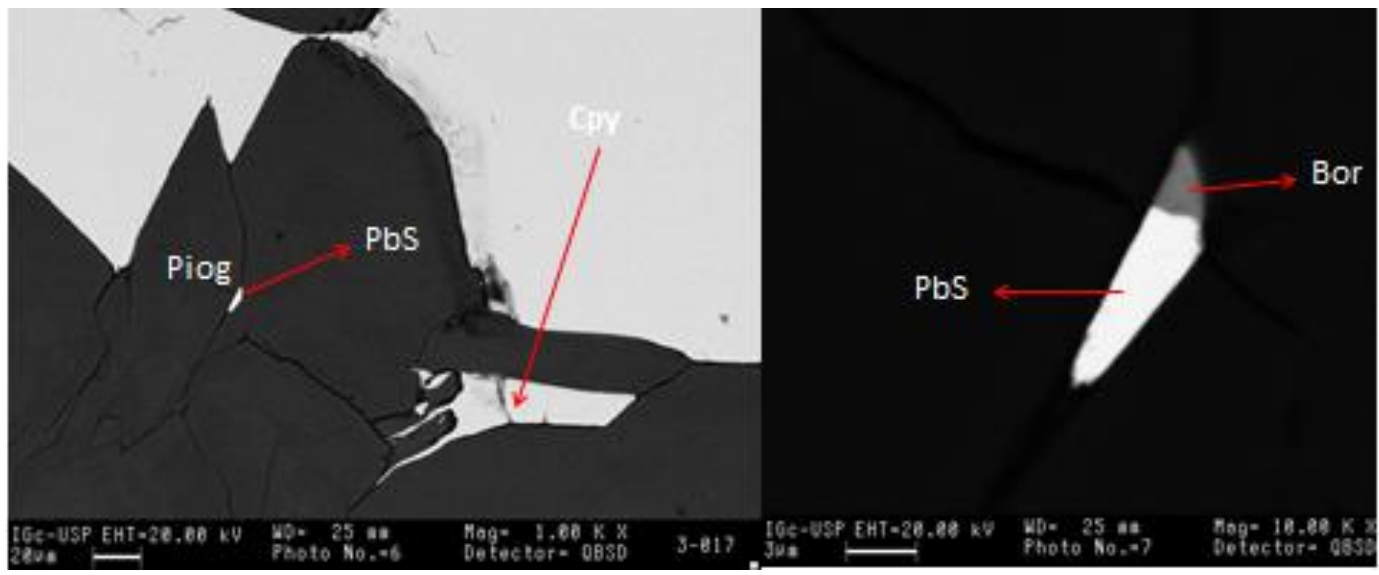

Figura 16. Imagem de Microscopia Eletrônica de Varredura de galena associada a bornita 

Noroeste de Moçambique.

Uma varredura de detalhe foi feita na calcopirita e bornita, onde foram reconhecidos sulfetos que contém cobre, bismuto e antimónio (Fig.17) ocorrendo como exsoluções e em forma de vênulas.

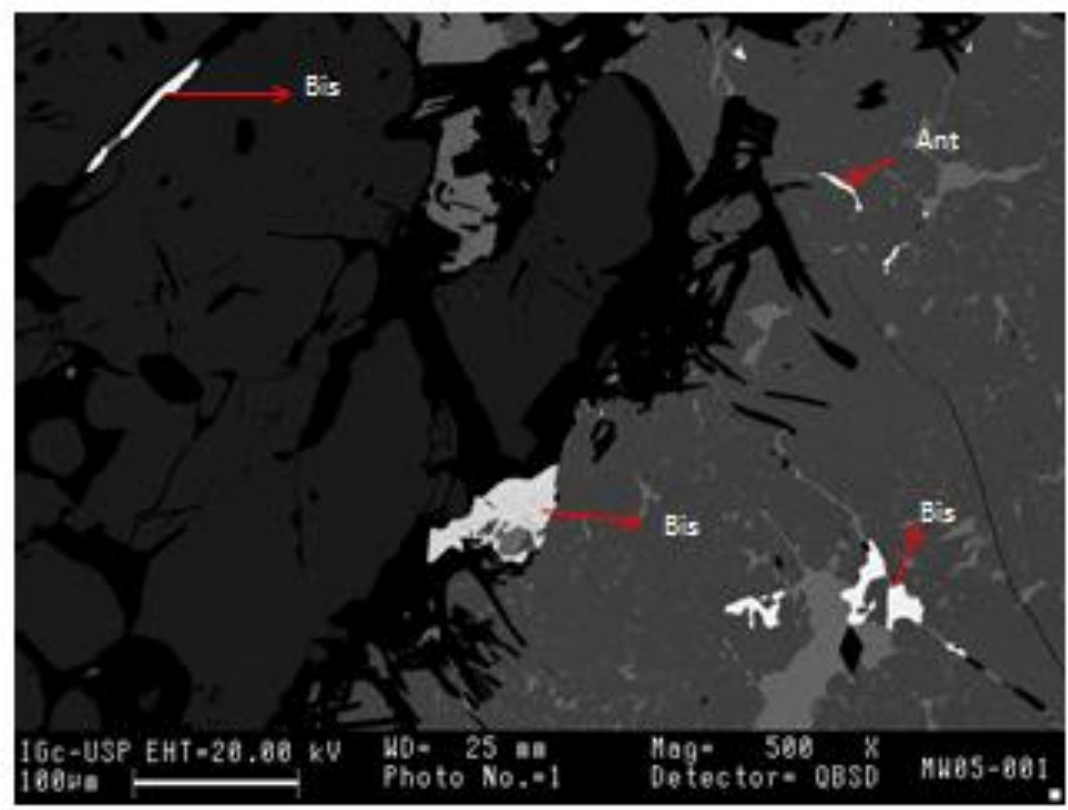

Figura 17- Imagem de Microscopia Eletrônica de Varredura de bismuto (Bis) tetraedrita, ocorrendo como exsolução na bornita e sem orientação.

A prata não foi observada como mineral isolado, geralmente ocorre associada ao telúrio e ao ouro. Este mineral ocorre em pequenas porções e é muito fina, que dificulta a observação. Este pode ser encontrado em veios de quartzo e carbonato (fig18). 

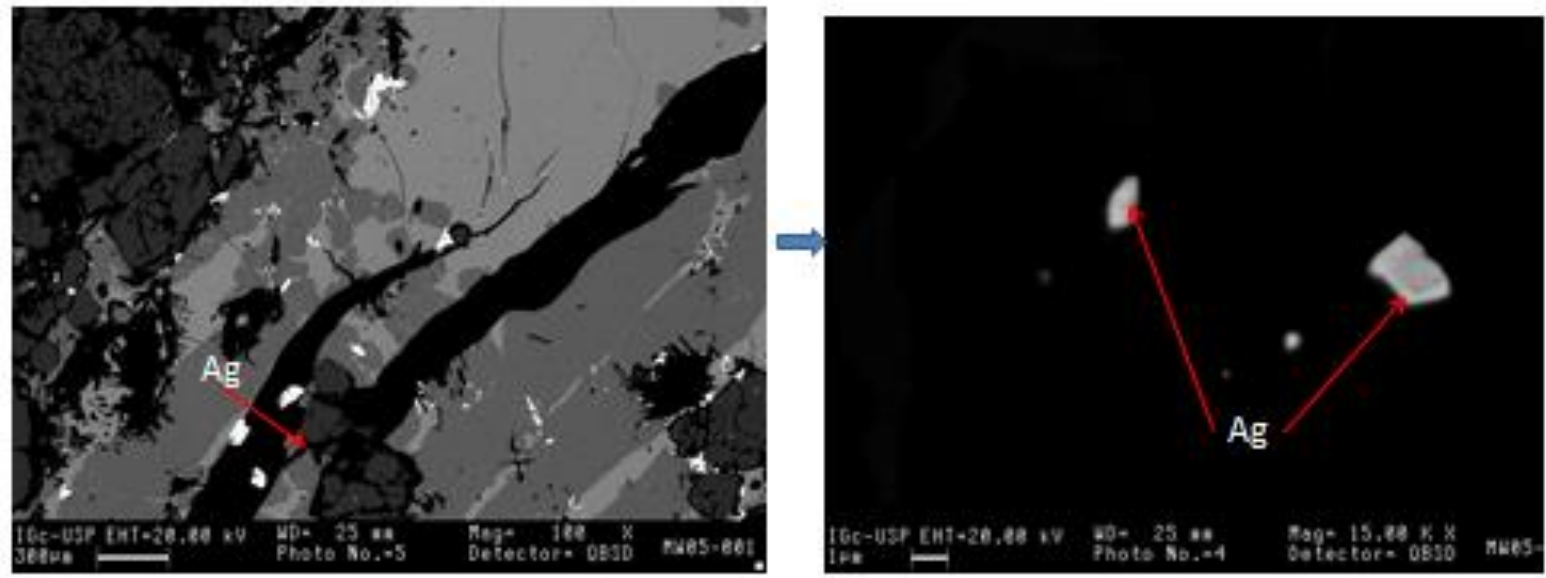

Figura 18. Imagem de Microscopia Eletrônica de Varredura mostrando a prata (Ag) que ocorre associada ao telúrio em veios de quartzo e carbonato.

O ouro ocorre associado à prata, em pequenas porções, e encontra-se disseminado em veios de quartzo e carbonato (Fig.19).
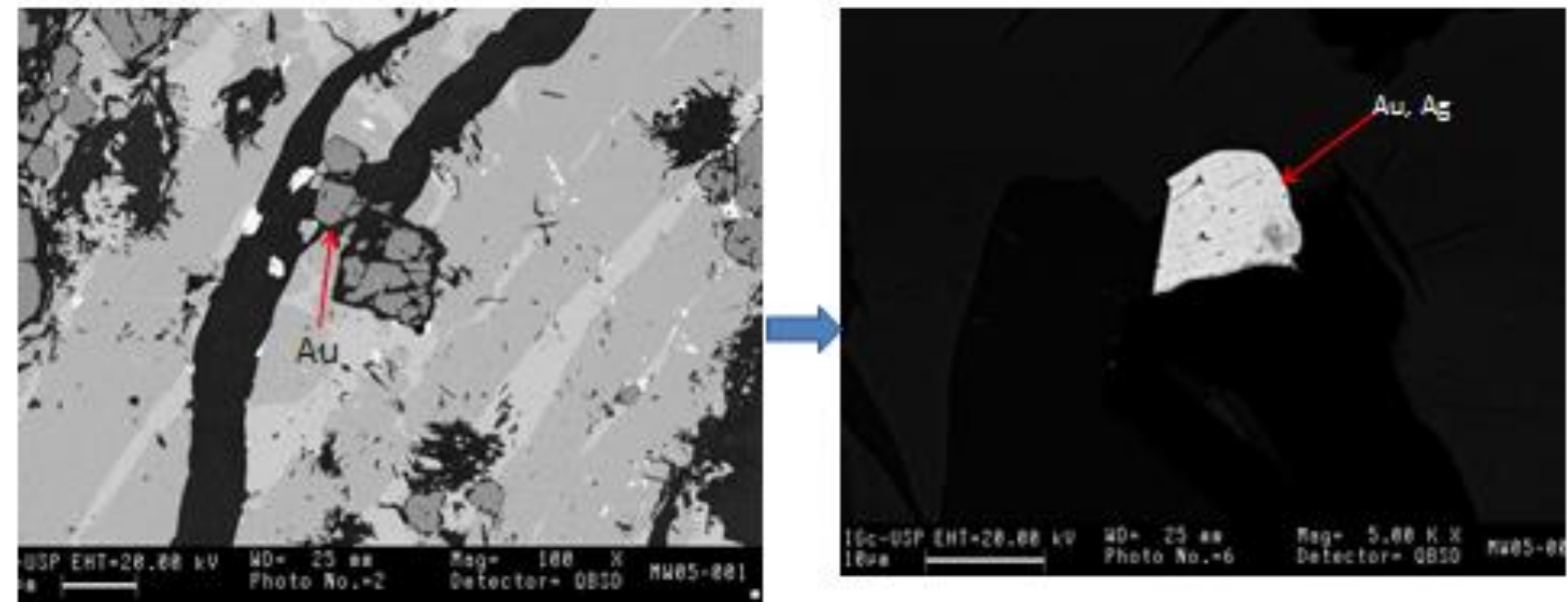

Figura 19- Imagem de Microscopia Eletrônica de Varredura de ouro (Au) associada à prata $(\mathrm{Ag})$ em veios de quartzo e carbonato.

Foram observados óxido de Magnetita inclusa na calcopirita, nas camadas de actinolitatremolita, que se mostram com uma orientação preferencial (Fig. 20). 


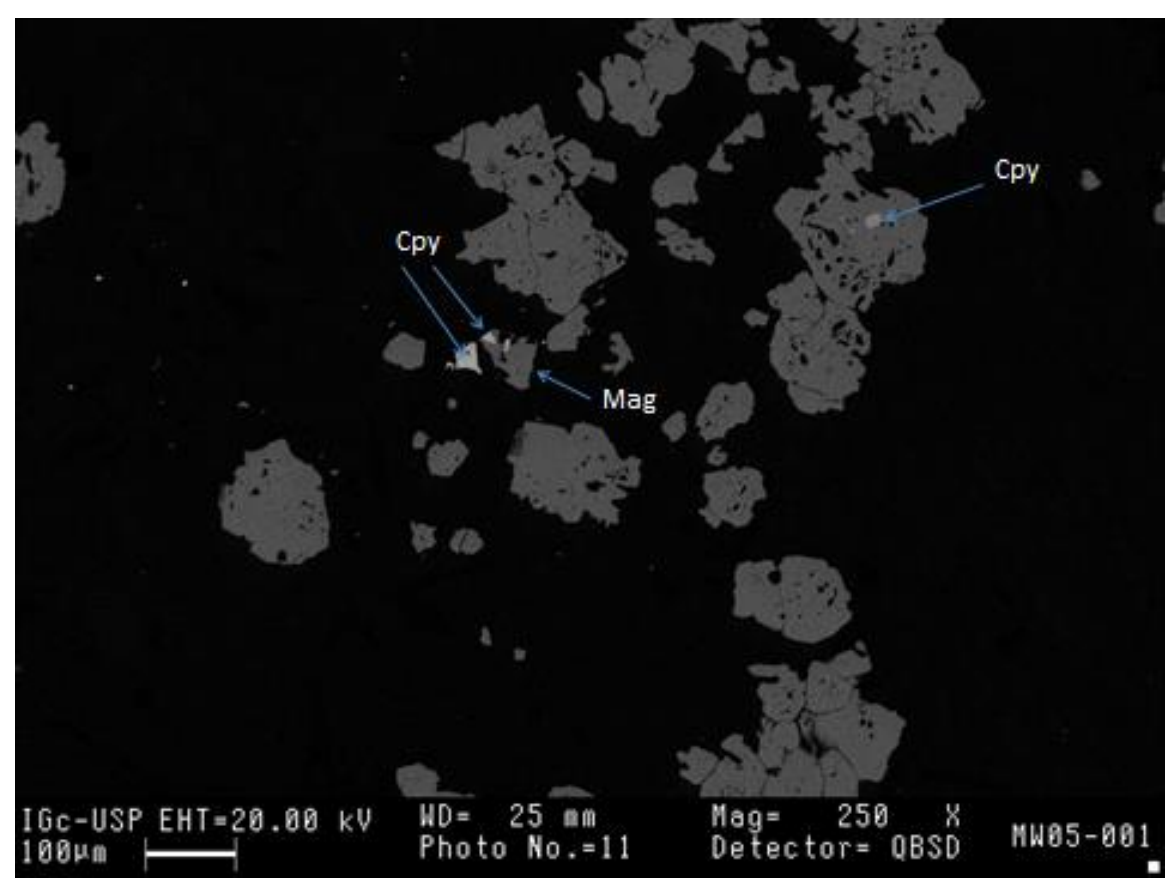

Figura 20-Imagem de Microscopia Eletrônica de Varredura MEV mostrando a magnetita (Mag), associada à calcopirita (Cpy).

\section{3 - Geocronologia e Geologia Isotópica}

Neste trabalho foram realizadas análises isotópicas pelo método U-Pb em zircão por microssonda iônica de alta resolução tipo SHRIMP IIe do Granito do Monte Muinga, análises Sm-Nd em rocha total e minerais separados do Gabro do Monte Muinga, análises de $\mathrm{Pb}-\mathrm{Pb}$ em calcopirita e calcita da mineralização, sendo que na amostra de calcita foi também realizada uma análise Sr/Sr. Os dados analíticos relativos a essas análises constam das Tabelas 4, 5, 6 e 7.

\subsection{1-Análises $U-P b$}

Os cristais de zircão usados para a análise isotópica pelo método U-Pb (SHRIMP) são provenientes da amostra MW04/002P que corresponde a um granito tipo I pertencente ao grupo do Monte Messuco - formação Monte Muinga. Este granito petrograficamente apresenta uma assembleia mineral dominada por microclínio, ortoclásio, plagioclásio, hornblenda, com quantidades de sulfetos inferiores a $1 \%$. Estes cristais de zircão analisados são translúcidos 
avermelhados, prismáticos com arestas arredondadas, com algumas inclusões ou fraturas. Nas imagens de catodoluminiscência (CL) é possível observar a presença zircões euédricos, com

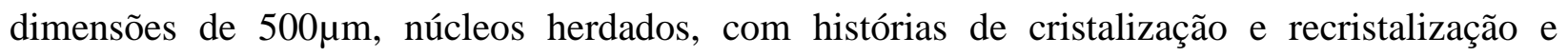
zoneamento oscilatório que é a textura predominante nestes zircões, e que segundo Hoskin, et.al (2000) é uma evidência de que os zircões cristalizaram-se em um período de tempo longo de resfriamento de magma. Este zoneamento oscilatório é normalmente correlacionado com as variações significativas na abundância de elementos químicos como $\mathrm{Zr}$, Si e elementos terras raras. A estrutura oscilatória observada nas imagens de CL sugere uma variação composicional em dois membros: (i) com composição muito baixa em elementos traços, aproximando-se da composição de zircão puro, refletindo-se em zonas de alta luminescência e (ii) zircão altamente enriquecido em elementos traços e com teores altos de $\mathrm{U}$, refletindo-se em zonas de baixa luminescência. Os zircões com zoneamento oscilatório são de origem ígnea, ao passo que o zoneamento setorial ou zonas de sobrecrescimento, são comuns nos zircões metamórficos.

Foram selecionados 84 grãos de zircão com morfologias diversas e datados 23 pontos (spots) em 22 cristais (Fig. 21). Vinte e dois grãos apresentam discordância absoluta menor ou igual a 5\%, mas doze apresentam uma discordância inversa. A idade obtida no spot 2.1 apresenta uma discordância acima da faixa desses valores (28\%) por isso não será considerada nas interpretações. Os cristais de zircão analisados são todos de origem magmática, como indicam as razões ${ }^{232} \mathrm{Th} /{ }^{238} \mathrm{U}$ relativamente altas (tabela 4). As imagens de catodoluminescência confirmam esta evidência, mostrando zoneamento oscilatório magmático típico, que se apresenta em núcleos e /ou sobrecrescimento magmático em quase todos os cristais (Fig. 21). 
Estudos Petrográficos e Geocronológicos do Prospecto Mankombiti, Cinturão de Fíngoè, Província de Tete Noroeste de Moçambique.

Tabela 4- Dados analíticos U/Pb (SHRIMP) da amostra MW04/002P

\begin{tabular}{|c|c|c|c|c|c|c|c|c|}
\hline spots & $\begin{array}{c}\mathrm{U} \\
(\mathrm{ppm})\end{array}$ & $\begin{array}{c}\text { Th } \\
\text { (ppm) }\end{array}$ & $\begin{array}{c}\text { Pb* } \\
\text { (ppm) }\end{array}$ & ${ }^{232} \mathrm{Th} /{ }^{238} \mathrm{U}$ & $\begin{array}{l}\text { Dis } \\
(\%)\end{array}$ & ${ }^{207} \mathrm{~Pb} /{ }^{235} \mathrm{U}$ & ${ }^{206} \mathrm{~Pb} /{ }^{238} \mathrm{U}$ & $\begin{array}{c}{ }^{207} \mathbf{P b} /{ }^{206} \mathbf{P b} \\
\text { T (Ma) }\end{array}$ \\
\hline 1.1 & 463 & 492 & 0.08 & 1.10 & 3 & $1.87 \pm 1.0$ & $0.1785 \pm 0.4$ & $1092 \pm 17$ \\
\hline 2.1 & 895 & 252 & 1.77 & 0.29 & 28 & $1.13 \pm 3.7$ & $0.1175 \pm 0.4$ & $916 \pm 77$ \\
\hline 2.2 & 386 & 369 & 0.00 & 0.99 & 0 & $1.84 \pm 1.0$ & $0.1790 \pm 0.4$ & $1058 \pm 19$ \\
\hline 3.1 & 341 & 329 & 0.00 & 1.00 & -2 & $1.97 \pm 1.0$ & $0.1886 \pm 0.4$ & $1086 \pm 19$ \\
\hline 4.1 & 408 & 477 & 0.04 & 1.21 & 0 & $1.95 \pm 1.2$ & $0.1858 \pm 0.4$ & $1095 \pm 22$ \\
\hline 5.1 & 248 & 217 & 0.14 & 0.90 & -2 & $1.91 \pm 1.3$ & $0.1846 \pm 0.5$ & $1067 \pm 24$ \\
\hline 6.1 & 420 & 517 & 0.11 & 1.27 & 3 & $1.88 \pm 1.1$ & $0.1793 \pm 0.4$ & $1097 \pm 20$ \\
\hline 7.1 & 291 & 279 & 0.00 & 0.99 & -2 & $1.91 \pm 1.1$ & $0.1845 \pm 0.5$ & $1073 \pm 20$ \\
\hline 8.1 & 371 & 407 & 0.12 & 1.13 & -1 & $1.89 \pm 1.3$ & $0.1825 \pm 0.7$ & $1069 \pm 21$ \\
\hline 9.1 & 299 & 267 & 0.03 & 0.92 & -3 & $1.93 \pm 1.1$ & $0.1864 \pm 0.5$ & $1069 \pm 21$ \\
\hline 10.1 & 393 & 446 & 0.08 & 1.17 & -2 & $1.95 \pm 1.2$ & $0.1872 \pm 0.7$ & $1085 \pm 18$ \\
\hline 11.1 & 321 & 294 & 0.03 & 0.95 & 0 & $1.96 \pm 1.1$ & $0.1863 \pm 0.5$ & $1100 \pm 20$ \\
\hline 12.1 & 436 & 517 & 0.00 & 1.23 & -2 & $1.92 \pm 0.9$ & $0.1858 \pm 0.4$ & $1071 \pm 17$ \\
\hline 13.1 & 299 & 306 & 0.13 & 1.06 & -3 & $1.90 \pm 1.3$ & $0.1846 \pm 0.5$ & $1058 \pm 24$ \\
\hline 14.1 & 264 & 234 & 0.05 & 0.92 & -3 & $1.90 \pm 1.3$ & $0.1848 \pm 0.6$ & $1062 \pm 24$ \\
\hline 15.1 & 300 & 291 & 0.00 & 1.00 & -5 & $1.94 \pm 1.1$ & $0.1887 \pm 0.5$ & $1061 \pm 20$ \\
\hline 16.1 & 198 & 138 & 0.13 & 0.72 & -1 & $1.99 \pm 1.5$ & $0.1891 \pm 0.6$ & $1107 \pm 28$ \\
\hline 17.1 & 319 & 308 & 0.11 & 1.00 & 6 & $1.89 \pm 1.2$ & $0.1782 \pm 0.5$ & $1116 \pm 21$ \\
\hline 18.1 & 66 & 92 & 0.00 & 1.44 & 4 & $1.95 \pm 2.5$ & $0.1832 \pm 1.0$ & $1130 \pm 46$ \\
\hline 19.1 & 254 & 265 & 0.17 & 1.08 & 1 & $1.84 \pm 1.6$ & $0.1778 \pm 0.7$ & $1068 \pm 28$ \\
\hline 20.1 & 339 & 324 & 0.20 & 0.99 & -2 & $1.87 \pm 1.3$ & $0.1816 \pm 0.5$ & $1058 \pm 25$ \\
\hline 21.1 & 301 & 232 & 0.00 & 0.80 & 0 & $1.87 \pm 1.1$ & $0.1810 \pm 0.5$ & $1070 \pm 20$ \\
\hline 22.1 & 350 & 326 & 0.00 & 0.96 & 0 & $1.90 \pm 1.0$ & $0.1823 \pm 0.4$ & $1081 \pm 18$ \\
\hline 23.1 & 477 & 577 & 0.06 & 1.25 & 0 & $1.93 \pm 1.0$ & $0.1847 \pm 0.4$ & $1091 \pm 18$ \\
\hline
\end{tabular}



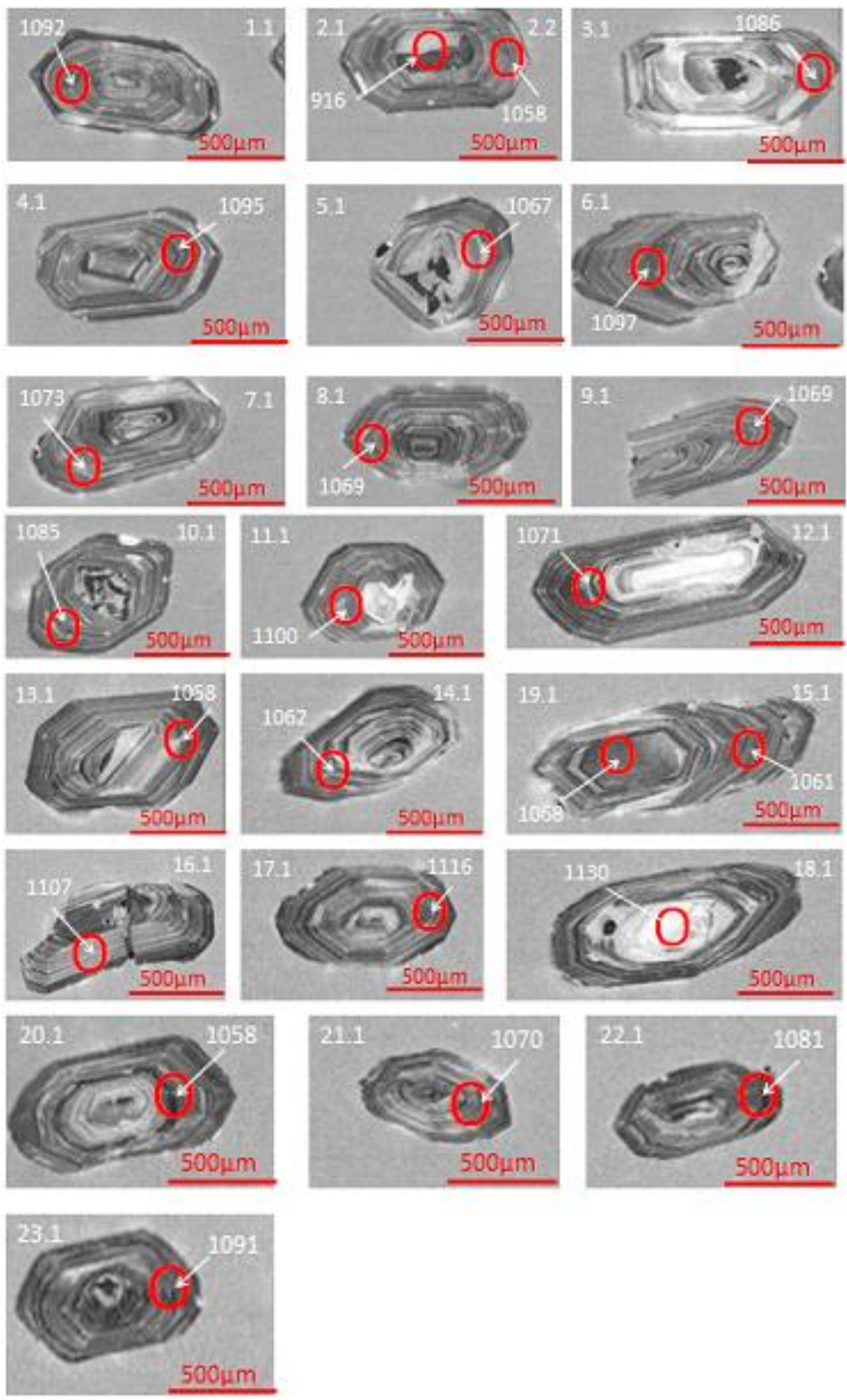

Figura 21- Imagens de catodoluminescência dos zircões analisados da amostra MW04/002P 
As idades obtidas em cada um dos spots analisados são pouco discordantes, e a média das idades ${ }^{207} \mathrm{~Pb} /{ }^{206} \mathrm{~Pb}$ é de 1079,5 \pm 7,2 Ma (MSWD = 2,5) (Fig. 22). Estes pontos quando lançados no Diagrama Concórdia da figura 23 indicaram uma idade no intercepto superior de 1079,1 $\pm 8,2$ Ma. As idades obtidas são concordantes e indica a idade de 1079 Ma como idade de cristalização magmática desta rocha.

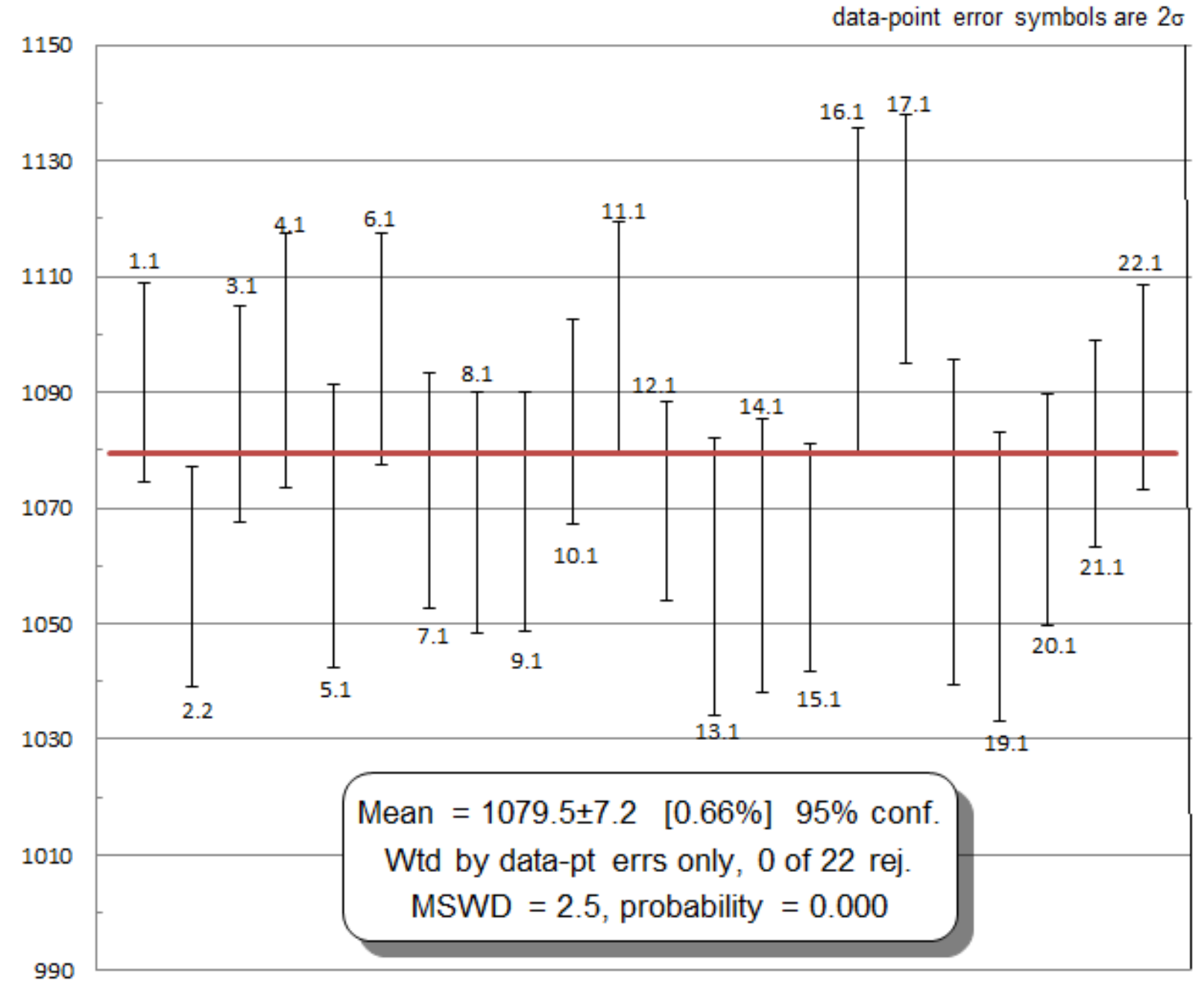

Figura 22- Média das idades ${ }^{207} \mathrm{~Pb} /{ }^{206} \mathrm{~Pb}$ dos zircões da amostra MW04/002P 


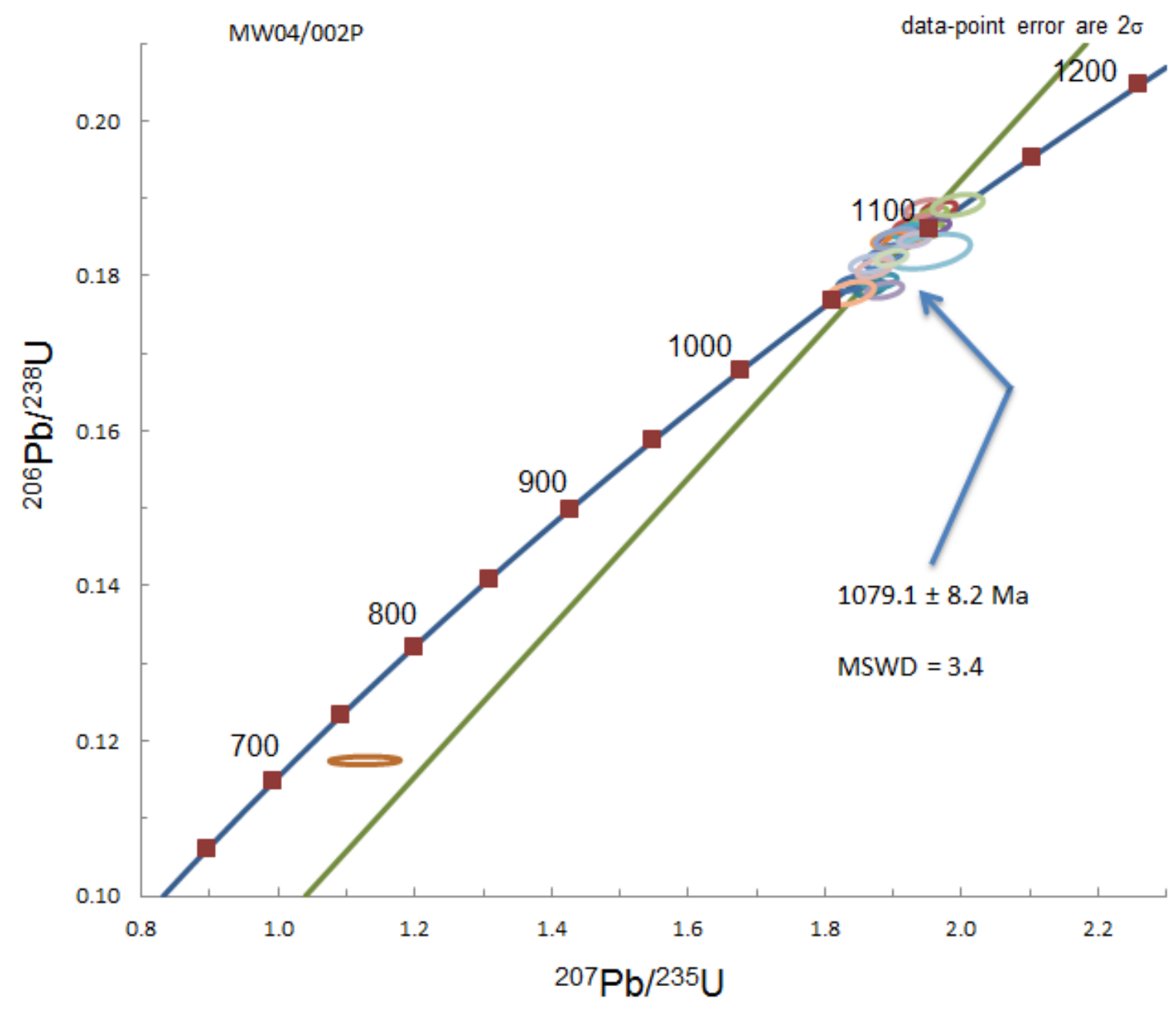

Figura 23 - Diagrama concórdia U-Pb para a amostra MW04/002P

\subsection{2-Análises Sm-Nd}

Foram analisadas pelo método Sm-Nd amostras de um corpo de gabro com evidências de alteração hidrotermal, sendo analisadas amostras de rocha total e concentrados de piroxênio e plagioclásio. Os litotipos analisados por este método incluem principalmente $\mathrm{Px} \pm \mathrm{Plg} \pm \mathrm{Qtz}$ e apresentam uma alteração pervasiva do piroxênio e plagioclásio. 
Estudos Petrográficos e Geocronológicos do Prospecto Mankombiti, Cinturão de Fíngoè, Província de Tete Noroeste de Moçambique.

Tabela 5. Dados analíticos Sm-Nd em rocha total e em minerais do Gabro

\begin{tabular}{|c|c|c|c|c|c|c|c|c|c|c|}
\hline No. Campo & Material & $\begin{array}{l}\text { Sm } \\
(\mathbf{p p m})\end{array}$ & $\begin{array}{l}\text { Nd } \\
(\text { ppm) }\end{array}$ & $\begin{array}{l}{ }^{147} \mathrm{Sm} / \\
{ }^{144} \mathrm{Nd}\end{array}$ & $\begin{array}{l}{ }^{143} \mathrm{Nd} / \\
{ }^{144} \mathrm{Nd}\end{array}$ & $\begin{array}{l}\mathbf{f}_{\mathrm{Sm} /} \\
\mathrm{Nd}\end{array}$ & $\begin{array}{l}T_{D M} \\
(\mathbf{G a})\end{array}$ & $\begin{array}{l}\mathcal{E}_{\mathrm{Nd}} \\
(\mathrm{TDM})\end{array}$ & $\begin{array}{l}\mathcal{E}_{\mathrm{Nd}} \\
(0.66 \mathrm{Ga})\end{array}$ & $\begin{array}{l}\mathcal{E}_{\mathrm{Nd}} \\
(1.08 \mathrm{Ga})\end{array}$ \\
\hline MW03/033PO & RTO & 2.203 & 7.970 & 0.1672 & 0.512363 & -0.15 & 2.23 & 3.05 & -2.88 & -1.29 \\
\hline MW03/033PO & Piroxênio & 2.744 & 10.190 & 0.1628 & 0.512358 & -0.17 & & & & \\
\hline MW03/033PO & Plagioclásio & 0.676 & 2.507 & 0.1629 & 0.512305 & -0.17 & & & & \\
\hline ME05/003P & RTO & 3.289 & 14.236 & 0.1397 & 0.512254 & -0.29 & 1.62 & 4.29 & -2.72 & +0.34 \\
\hline ME05/003P & Piroxênio & 2.444 & 9.262 & 0.1596 & 0.512402 & -0.19 & & & & \\
\hline ME05/003P & Plagioclásio & 3.802 & 18.614 & 0.1235 & 0.512180 & -0.37 & & & & \\
\hline
\end{tabular}

Nas amostras de rocha total (MW03/033PO e ME05/003P) os teores de Sm e Nd são respectivamente 2,203 e 7,970 ppm e 3,289 e 14,236 ppm. As razões isotópicas ${ }^{147} \mathrm{Sm} /{ }^{144} \mathrm{Nd}$ e ${ }^{143} \mathrm{Nd} /{ }^{144} \mathrm{Nd}$ variam entre 0,1672 e 0,512363 e 0,1397 e 0,512254 , respectivamente. Os concentrados de plagioclásio sericitizado apresentaram teores de Sm e Nd de 0,676 e 2,507 ppm, para a amostra MW03/33PO e 3,802 e 18,614 ppm para a amostra ME05/003P, e os concentrados de piroxênio epidotizados possuem teores de $\mathrm{Sm}$ e $\mathrm{Nd}$ de 2,744 e 10,190 ppm e 2,444 e 9,262 ppm respectivamente, (Tabela 5).

Como os ETRs possuem certa mobilidade em fluidos hidrotermais, os valores de $\mathrm{Sm}$ e $\mathrm{Nd} \mathrm{em}$ $\mathrm{ppm}$, podem refletir interação fluido-rocha que produziu o fracionamento da razão $\mathrm{Sm} / \mathrm{Nd} \mathrm{em}$ escala de minerais e de rocha total.

A alteração hidrotermal que afetou estas amostras é do tipo pervasiva, com os cristais de piroxênio apresentando-se epidotizados na sua maioria, e em alguns casos é possível observar anfibólios nas bordas destes piroxênios. Nos cristais de plagioclásio a saussuritização é muito expressiva e em alguns cristais é notória a albitização nas bordas e os núcleos geralmente aparecem epidotizados.

Quando lançados no diagrama isocrônico $\mathrm{Sm}-\mathrm{Nd}$, os pontos analíticos relativos aos concentrados de piroxênio da amostra ME05 e de plagioclásio da amostra MW03 não se alinharam com os demais. Estes minerais correspondem aos minerais mais fortemente afetados por epidotização e sericitização respectivamente. Possivelmente com o piroxênio tendo perdido Sm ou ganho $\mathrm{Nd}$ em relação ao plagioclásio que teria recebido o Sm ou cedido o Nd, (Fig.24). Mas de toda a 
forma admite-se que essas amostras tiveram o sistema aberto e com a adição de minerais hidratados possivelmente tenha perturbado a química do sistema original.

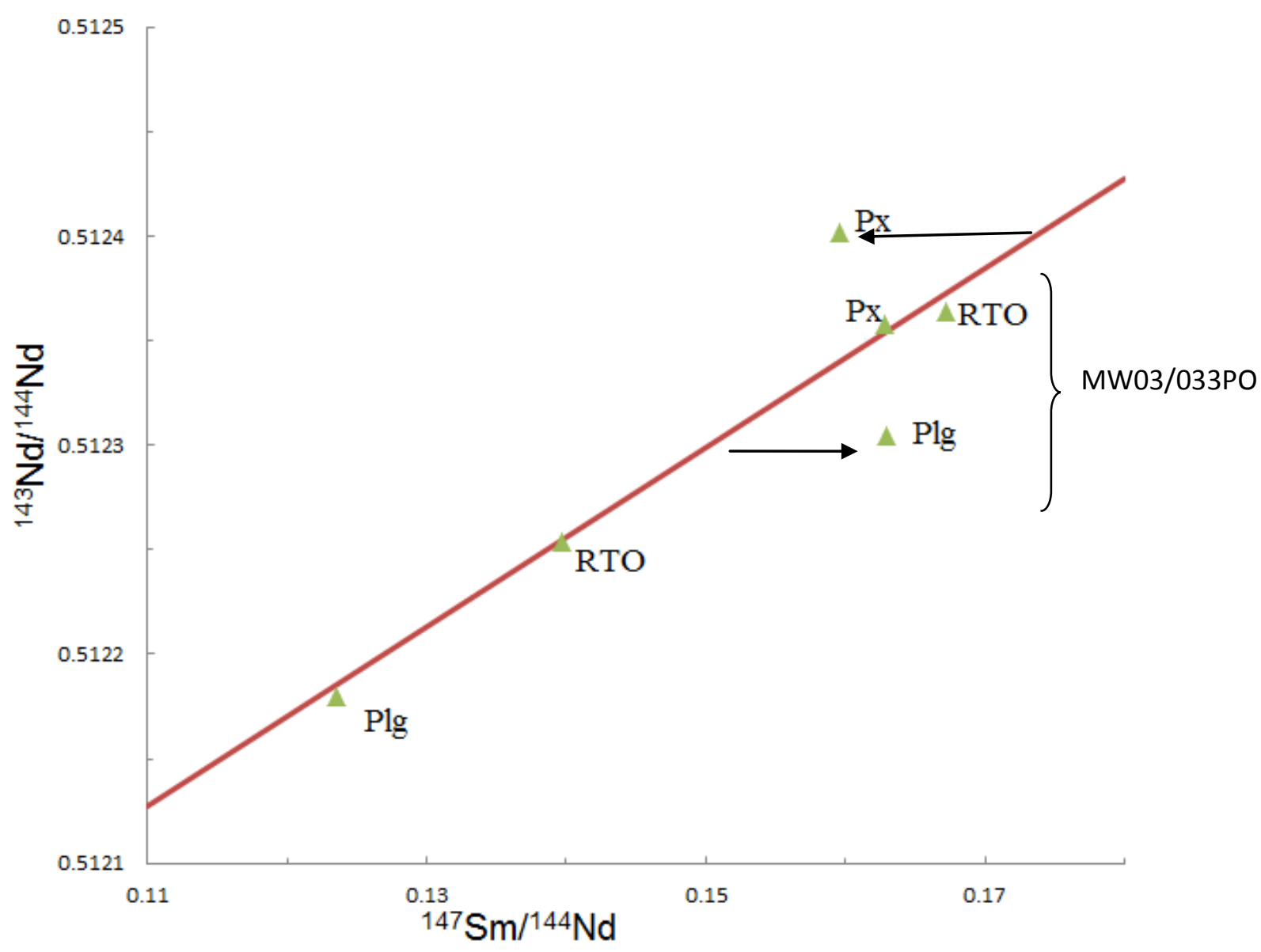

Figura 24- Diagrama Isócronico Sm-Nd do gabro do Monte Muinga

Quatro pontos analíticos, relativos às amostras de rocha total (ME05/003P e MW03/033PO) do plagioclásio da amostra ME05/003P e do piroxênio da amostra MW03/003PO definiram no diagrama isocrônico Sm-Nd uma reta com inclinação relativa a idade de $657 \pm 36$ Ma, com valor de MSWD de 2,3 (Fig. 25), interpretada como idade do evento de alteração hidrotermal que afetou o gabro estudado. 


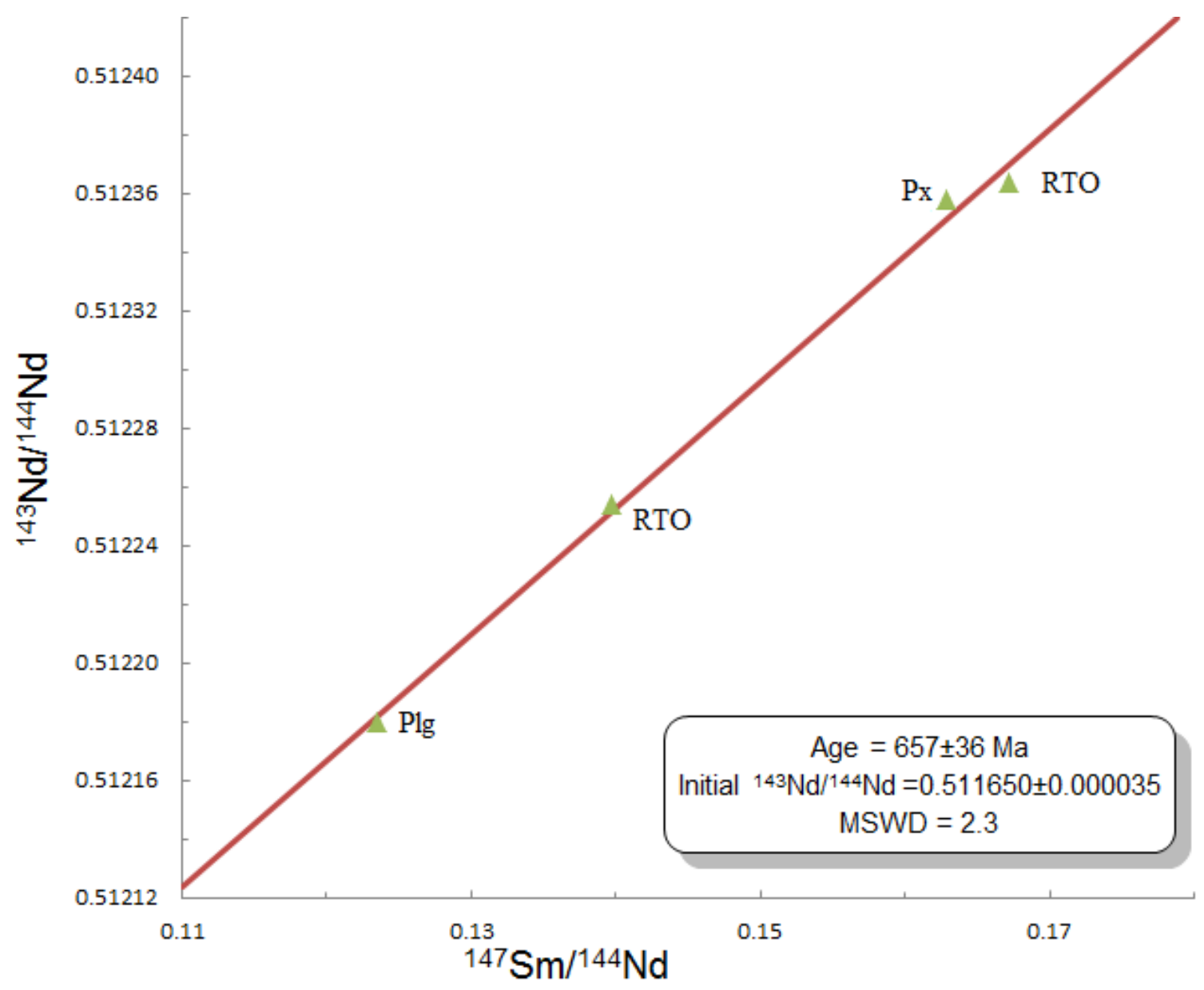

Figura 25. Diagrama Isócronico Sm-Nd do gabro do Monte Muinga

Os valores de $\varepsilon_{\mathrm{Nd}}$ das amostras de rocha total do gabro, quando calculados para idade de alteração hidrotermal de $0,66 \mathrm{Ga}$ foram de -2,88 e -2,72. Em adição foi também realizada uma análise $\mathrm{Rb}-\mathrm{Sr}$ em rocha total de uma destas amostras (ME06), cujos dados analíticos estão listados na Tabela 6.

Tabela 6- Dados analíticos $\mathrm{Rb}-\mathrm{Sr}$

\begin{tabular}{|c|c|c|c|c|c|c|c|}
\hline Amostra & Material/ Rocha & $\mathbf{R b}$ (ppm) & $\mathrm{Sr}$ (ppm) & ${ }^{87} \mathrm{Rb} /{ }^{86} \mathrm{Sr}$ & Erro (1ס) & ${ }^{87} \mathrm{Sr} /{ }^{86} \mathrm{Sr}$ & 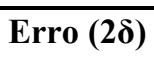 \\
\hline ME06/001PO & RTOT/Gabro & 39.36 & 271.48 & 0.4197 & 0.0000 & 0.709463 & 0.000061 \\
\hline MW03/001P & Mármore/Calcita & - & - & - & - & 0.705791891 & 0.000041 \\
\hline
\end{tabular}

As razões isotópicas ${ }^{87} \mathrm{Sr} /{ }^{86} \mathrm{Sr}$ foram normalizadas para o valor de ${ }^{86} \mathrm{Sr} /{ }^{88} \mathrm{Sr}=0,1194$ 
O valor calculado para a razão ${ }^{87} \mathrm{Sr} /{ }^{86} \mathrm{Sr}$ em 0,66 Ga foi de 0,70512 . Estes valores sugerem, para o caso do gabro ter sido formado no neoproterozóico $(\sim 0,7 \mathrm{Ga})$, que o magma parental deste corpo foi derivado do manto superior, envolvendo processo de contaminação crustal. Considerando a alternativa deste corpo de gabro ser mesoproterozóico e associado à série do granito do Monte Muinga com idade próxima a 1079 Ma e que é intrusiva na sequência metavulcano-sedimentar de Fíngoè, que possui idade de deposição próxima a 1,33 Ga (GTK, consortium 2006), os valores de $\varepsilon_{\mathrm{Nd}}$ calculados para o gabro seriam de $-1,29$ e $+0,34$ e o valor calculado para a razão ${ }^{87} \mathrm{Sr} /{ }^{86} \mathrm{Sr}$ seria de 0,702 . Esses valores indicariam que tais rochas seriam formadas a partir de magmas mantélicos com contaminação de rochas da crosta continental inferior pré-existente.

Como demonstrado acima as duas amostras de gabro analisadas em rocha total apresentaram fracionamento da razão $\mathrm{Sm} / \mathrm{Nd}$ por ação de circulação de fluidos hidrotermais, apresentando valores da razão ${ }^{147} \mathrm{Sm} /{ }^{143} \mathrm{Nd}$ de 0,1672 e 0,1397 , fora do intervalo entre 0,09 e 0,129 estabelecido para rochas não fracionadas (Sato et al, 1997). As idades Sm-Nd modelo manto empobrecido foram, portanto, calculadas em dois estágios, conforme De Paolo, (1981), utilizando o segundo estágio a partir de $700 \mathrm{Ma}$, época do processo de alteração hidrotermal, processo este que produz fracionamento entre os elementos Terras Raras. Desta maneira foram obtidas as idades $\mathrm{T}_{\mathrm{DM}}$ de 1.58 e $1.55 \mathrm{Ga}$ indicativas da média entre a época da diferenciação mantélica do magma parental desta rocha e dos protólitos das rochas continentais contaminantes.

\subsection{3- Análises $P b-P b$}

Para as análises isotópicas realizadas pelo método $\mathrm{Pb}-\mathrm{Pb}$, foram selecionadas 4 amostras de calcopirita disseminadas em rochas metassedimentares e gabróicas e uma amostra de calcita associada aos sulfetos analisados. As composições isotópicas ${ }^{206} \mathrm{~Pb} /{ }^{204} \mathrm{~Pb},{ }^{207} \mathrm{~Pb} /{ }^{204} \mathrm{~Pb}$ e ${ }^{208} \mathrm{~Pb} /{ }^{204} \mathrm{~Pb}$ variam nas amostras de calcopirita entre 17,815 e $18,988,15,631$ e 15,712 , e 37,718 e 37,963, repectivamente. A amostra de calcita apresentou valores de ${ }^{206} \mathrm{~Pb} /{ }^{204} \mathrm{~Pb},{ }^{207} \mathrm{~Pb} /{ }^{204} \mathrm{~Pb} \mathrm{e}$ ${ }^{208} \mathrm{~Pb} /{ }^{204} \mathrm{~Pb}$ de $20,178,15,799$ e 37,031 respectivamente. 
Tabela 7- Análises $\mathrm{Pb}-\mathrm{Pb}$

\begin{tabular}{llllllll}
\hline AMOSTRA & MATERIAL & ${ }^{206} \mathbf{P b} /{ }^{204} \mathbf{P b}$ & Erro & ${ }^{207} \mathbf{P b} /{ }^{204} \mathbf{P b}$ & $\begin{array}{c}\text { Erro } \\
{ }^{208} \mathbf{P b} /{ }^{204} \mathbf{P b}\end{array}$ & Erro \\
& & & 2s \% & & 2s \% & & 2s \% \\
\hline MW03/001PO & Calcita & 20.178 & 0.013 & 15.799 & 0.014 & 37.031 & 0.017 \\
MW05/001PO & Calcopirita & 17.815 & 0.005 & 15.665 & 0.007 & 37.773 & 0.009 \\
MW03/017PO & Calcopirita & 18.988 & 0.008 & 15.715 & 0.010 & 37.760 & 0.012 \\
MW02/029P & Calcopirita & 18.046 & 0.006 & 15.712 & 0.007 & 37.963 & 0.009 \\
ME06/001PO & Calcopirita & 17.829 & 0.010 & 15.631 & 0.010 & 37.718 & 0.011 \\
\hline
\end{tabular}

As razões isotópicas foram corrigidas para o fracionamento de massa de $0.095 \%$ u.m.a e o erro de $2 \delta \%$ - desvio padrão de de 2 sigmas (número médio de medidas $=60$ )

As composições isotópicas de $\mathrm{Pb}$ foram lançadas no diagrama ${ }^{207} \mathrm{~Pb} /{ }^{204} \mathrm{~Pb}$ vs. ${ }^{206} \mathrm{~Pb} /{ }^{204} \mathrm{~Pb}($ Fig. 26) com curvas de evolução isotópica de $\mathrm{Pb}$, do modelo da Plumbotectônica de Zartman \& Doe (1981) para a referência dos ambientes geológicos. Observa-se que os resultados das quatro amostras de calcopirita, situam-se sobre a curva da crosta superior ou acima dela, sugerindo que o $\mathrm{Pb}$ presente na calcopirita e na calcita associada foi derivado de rochas da crosta continental superior, com alta razão $\mathrm{U} / \mathrm{Pb}$, indicando que a mineralização em estudo foi formada a partir de circulação de fluidos hidrotermais que remobilizaram metais das rochas encaixantes. 


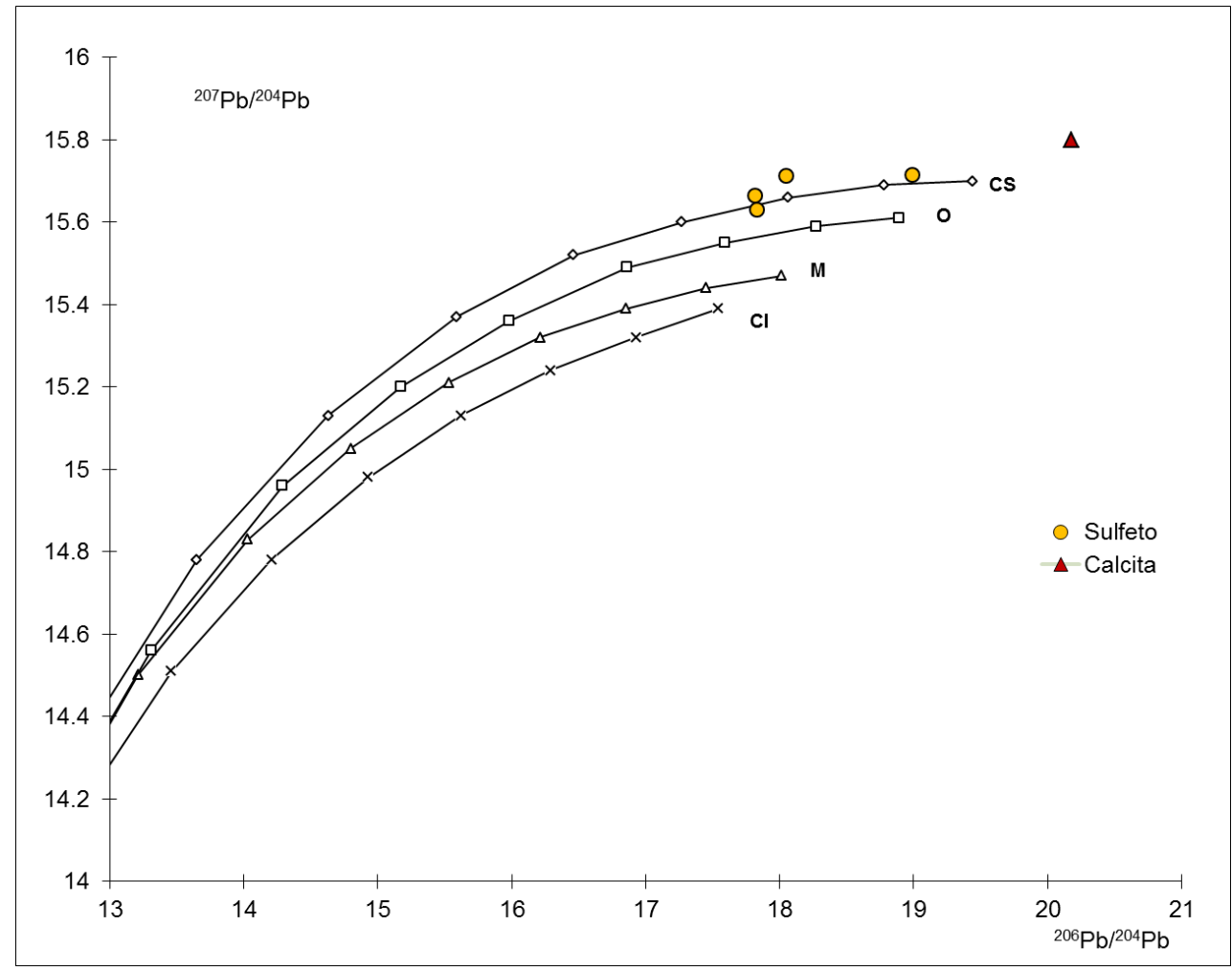

Figura 26- Diagrama Uranogênico de Zartman \& Doe (1981) mostrando as curvas de evolução de Pb na Crosta Superior (CS), Crosta Inferior (CI), Manto (M) e Orogênica (O). São indicadas as composições isotópicas de sulfeto e calcita.

Para a obtenção da idade aproximada desta mineralização, as composições isotópicas de $\mathrm{Pb}$ das amostras de calcopirita foram lançadas no diagrama ${ }^{206} \mathrm{~Pb} /{ }^{204} \mathrm{~Pb} v{ }^{207} \mathrm{~Pb} /{ }^{204} \mathrm{~Pb}$, onde consta a curva de evolução isotópica de Pb de Stacey e Kramers (1975) (SK). Três pontos definem um bom arranjo linear, que intercepta a curva SK próximo a $725 \mathrm{Ma}$ (Fig. 27), o que permite inferir esta idade modelo como próxima da época de circulação hidrotermal responsável pela formação e/ou remobilização da mineralização estudada. Esta idade conscide com a idade obtida pelo método Sm-Nd em amostras de gabro com alteração hidrotermal superimposta. 


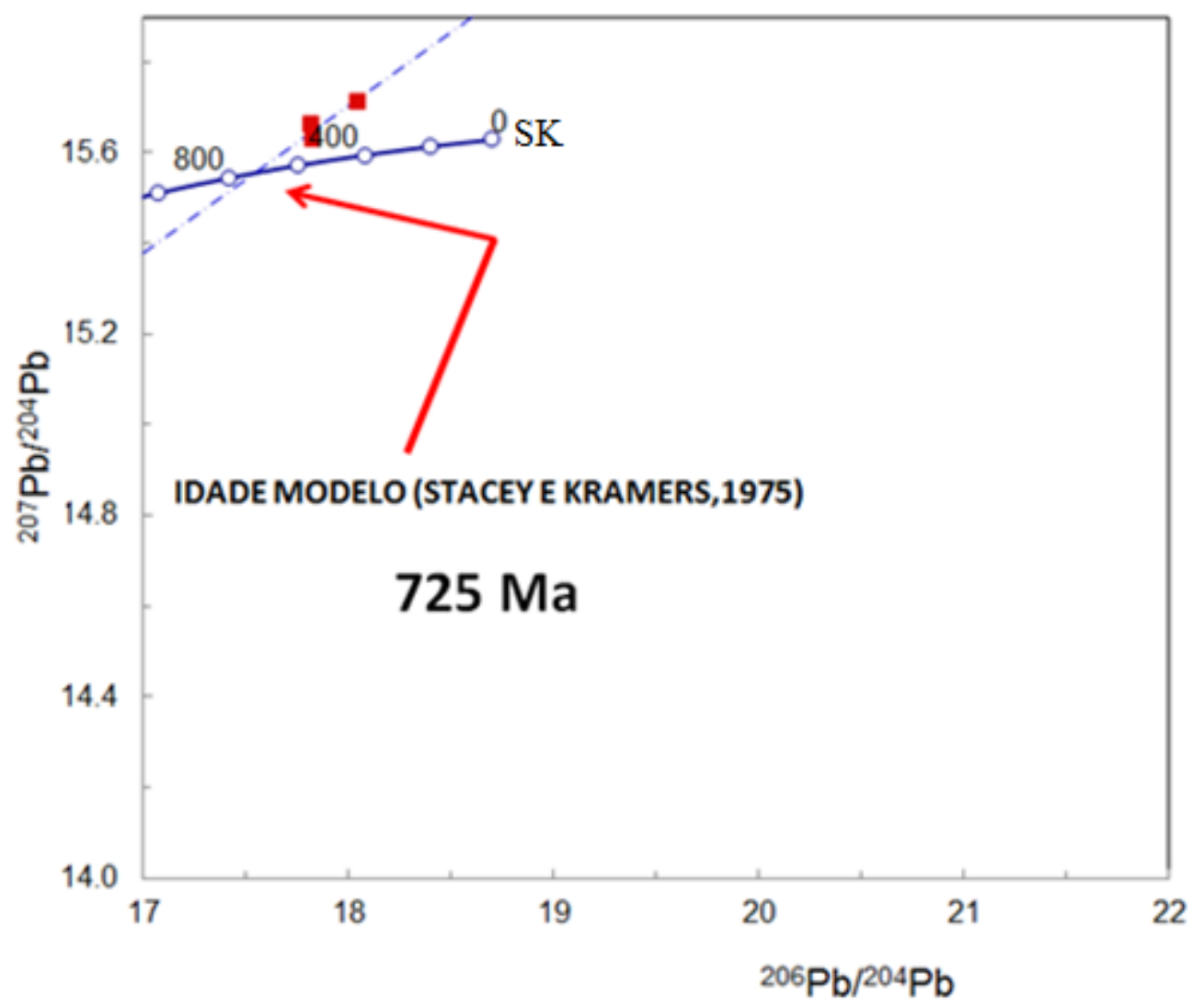

Figura 27-Diagrama ${ }^{206} \mathrm{~Pb} /{ }^{204} \mathrm{~Pb}$ vs ${ }^{207} \mathrm{~Pb} /{ }^{204} \mathrm{~Pb}$, para a calcopirita. A curva de evolução isotópica de $\mathrm{Pb}$ de Stacey \&Kramers (1975) esta lançada para a referência

\section{CONSIDERAÇÕES FINAIS}

Apesar de poucas amostras disponíveis para este estudo e a carência de trabalhos geológicos realizados até o momento na área de trabalho, foi possível obter dados que permitiram caracterizar os tipos de rochas presentes, as idades dos principais eventos geológicos que ocorreram na área e a fonte predominante dos fluidos hidrotermais associados com a mineralização de $\mathrm{Au}, \mathrm{Cu}$ e $\mathrm{Ag}$ estudada.

A mineralização objeto deste estudo está inserida no contexto geológico do cinturão Fíngoè que é constituído por uma extensa variedade de rochas metassedimentares e metavulcânicas (GTK consortium, 2006). Segundo estes autores, as rochas metavulcânicas do cinturão Fíngoè mostram 
uma variação em termos de composições químicas, do basalto ao riolito. As rochas foram classificadas como de transição entre alcalinas e sub-alcalinas no diagrama de $\mathrm{Na}_{2} \mathrm{O}+\mathrm{K}_{2} \mathrm{O}$ versus $\mathrm{SiO}_{2}$, ou como de transição entre toleiíticas a cálcio-alcalinas. Essas características associadas ao vulcanismo bimodal corroboram com o GTK, consortium, (2006) estabelecendo um ambiente colisional para a formação e deposição das rochas metavulcano-sedimentares de Fíngoè.

Este cinturão é intrudido por uma rocha intrusiva de composição granítica cálcio-alcalina de $1050 \pm 8 \mathrm{Ma}$, o que define uma idade mínima para a sequência metavulcano-sedimentar. Foi realizada uma datação U-Pb (SHRIMP) em zircão de rochas metavulcânicas félsicas do Grupo de Fíngoè a $57 \mathrm{~km}$ a oeste da área de estudo que indicou uma idade de $1327 \pm 16 \mathrm{Ma}$ (GTK consortium, 2006), sugerindo para este cinturão uma idade de deposição em torno de 1,3 Ga. Após a deposição e deformação, o cinturão Fíngoè foi intrudido ao norte e ao sul por vários granitos e granodioritos do tipo I e gabros de idade Mesoproterozóico a Neoproterozóico.

$\mathrm{O}$ cinturão Fíngoè apresenta especialização metalogenética para $\mathrm{Au}$ e $\mathrm{Cu}$, que já foram explotados no passado em diversos locais. Muitos destes registros estão associados com magnetita e malaquita. Uma revisão da geologia da área abrangida pelo prospecto King Solomon's mostra uma predominância de rochas carbonáticas, granitos e gabros. As rochas carbonáticas são consideradas importantes na gênese de depósitos tipo skarn e depósitos de substituição de metais de base e Au devido à sua natureza fortemente reativa. Os dados geológicos existentes revelam na área de estudo uma associação das unidades carbonáticas em contato tanto com rochas graníticas intrusivas bem como com as rochas gabróicas. Uma série de zonas de reação do tipo skarn é notada na área e estão associadas com metais de base e anomalias geoquímicas de Au (Christopher, 2010).

$\mathrm{Na}$ área específica do prospecto ocorrem metacarbonatos, rochas metassedimentares arenosas e argilosas que são intrudidos ao sul pelo granito epidoto-magnetita gerando a presença de escarnitos com o desenvolvimento de minerais de uma paragênese com $\mathrm{Px}+\mathrm{Kfds}+\mathrm{Plg}$. Geralmente os depósitos tipo skarns são dominados por rochas cálcio-silicatadas e minerais formados por substituição de litologias carbonáticas ou durante o metamorfismo regional ou por contato, processos metassomáticos relacionados a intrusões ígneas (Pirajno, 2009). A classificação de depósitos skarns deve ter em consideração tanto o tipo de rocha e a associação 
mineralógica da litologia substituída. Assim sendo os termos usados para referir a escarnitização de rochas ígneas e carbonáticas são endoskarn e exoskarn respectivamente. Einaudi (1982a) subdividiu os exoskarns em termos de suas assembleias minerais cálcio silicatadas em skarn cálcico e skarn magnesianos. Os skarns cálcicos são formados por substituição de calcários e contem minerais como granada, clinopiroxênios, wollastonita, escapolita, epidoto e magnetita, enquanto que os skarns magnesianos resultam da substituição de rochas dolomíticas e são compostos por minerais como a diopsidio, forsterita, serpentinita, magnetita, talco em ambientes pobres em sílica, e talco, Tremolita-actinolita em ambientes ricos em sílica.

Meinert et. al. (2005) considerou que os depósitos tipo skarn podem ocorrer em ambientes tectônicos com subducção de crosta oceânica, produção de magmatismo diorítico e granodiorítico e desenvolvimento de litologias carbonáticas com produção de skarns de $\mathrm{Fe}, \mathrm{Cu}$ e $\mathrm{Au}$, em ambientes de subducção transicional de baixo grau produzindo skarns de Mo, W-Mo associados com monazita e granitos; e subducção continental que inclui a maioria dos skarns, como $\mathrm{Zn}-\mathrm{Pb}, \mathrm{Cu}, \mathrm{Au}, \mathrm{W}, \mathrm{Mo}$, geralmente associados com granodiorito e granito, e rifteamento continental associado a plumas mantélicas resultando na colocação de granitos e skarns de Sn-W (Fig. 28). 

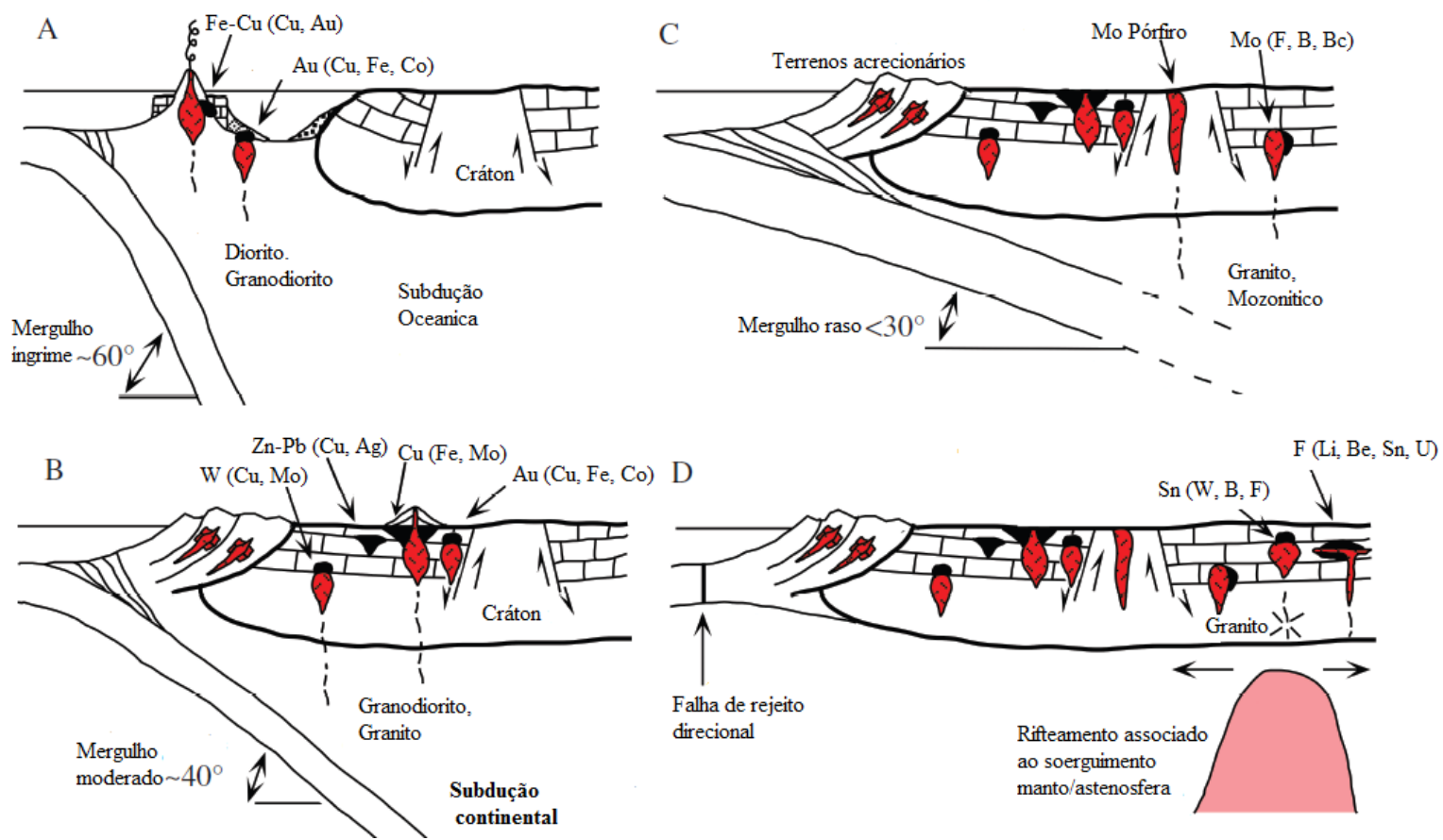

Figura 28- Modelos de ambientes tectônicos de formação de skarns; (A) Arco de ilha oceânica associados depósitos de carbonato íngremes; (B) Ambientes de subducção continental (C) Ambientes transicional de baixo ângulo; (D) Rifteamento continental definição com intrusões graníticas associadas a plumas do manto, Meinert et al.(2005).

$\mathrm{Na}$ área de estudo a mineralização ocorre próximo do contato entre o granito e a unidade de mármore, evidenciando a presença de depósitos tipo skarn, com a mineralização geralmente constituída por $\mathrm{Au}, \mathrm{Ag}, \mathrm{Cu}$ e $\mathrm{Zn}(+/-\mathrm{Pb})$ e com a magnetita associada. Foi também caracterizado neste estudo a presença de bismuto. A mineralização ocorre em veios e na matriz das brechas carbonáticas e como vênulas descontinuas nas rochas hospedeiras alteradas.

Os dados geocronológicos realizados neste trabalho indicaram uma idade precisa para a rocha intrusiva granítica associada à mineralização de 1079,1 \pm 8,2 Ma, que poderia ser a idade da formação do escarnito e consequentemente desta mineralização. Entretanto a idade obtida para o processo de alteração hidrotermal que afetou o gabro, da ordem de $657 \pm 36 \mathrm{Ma}$ e a idade sugerida pelo modelo de Stacey \& Kramers (1975) para a calcopirita da mineralização principal de 725 Ma, sugerem que a mineralização, do prospecto Mankombiti é neoproterozóica.

Duas hipóteses podem ser consideradas para explicar a recirculação de fluídos em 700 Ma gerando o processo de formação do skarn. No primeiro caso poderia ser admitida a presença de 
corpos graníticos intrusivos em $700 \mathrm{Ma}$, situados em profundidade, que não foram ainda caracterizados, como responsáveis pela fonte de calor necessária. A segunda possibilidade seria a ocorrência de um evento distensional em 700 Ma que produziria um adelgaçamento da litosfera e a consequente ascensão da astenosfera, que permitiria a manutenção de um regime de alto fluxo térmico necessário para a produção dos fluidos que geraram as mineralizações estudadas.

A composição isotópica de $\mathrm{Pb}$ das calcopiritas do skarn indicam rochas da crosta continental superior como as fontes predominantes da mineralização, e a presença de metais tais como bismuto, antimônio e cobre, também indicam as rochas graníticas como a principal fonte dos fluidos mineralizantes. Entretanto a hipótese do $\mathrm{Cu}$ e Fe terem sido remobilizados das rochas vulcânicas, não pode ser descartada.

Portanto pode-se resumir a evolução dos eventos do cinturão Fíngoè seguindo um modelo esquemático simples, sendo que: (i) houve a deposição e vulcanismo bimodal em ambiente de bacias do tipo "back arc" associadas a evento colisional, acompanhado de colocação de granitos cálcio-alcalinos, que poderia ter produzindo um metamorfismo de contato nas rochas carbonáticas, desenvolvendo um skarn e talvez uma mineralização precoce; (ii) Posteriormente em $0,7 \mathrm{Ga}$ poderia ter ocorrido um evento tectono-magmático, gerando forte circulação de fluídos e consequente aumento de processo hidrotermal acompanhado de atividade metassomática, produzindo a mineralização atual. Alternativamente, nesta época poderia ter ocorrido um evento distensional precoce ao desenvolvimento da orogenia pan-africana causando a ascensão da astenosfera e uma circulação de fluidos, aumento de processo hidrotermal e atividade metassomática, produzindo a mineralização atual.

Como sugestões para trabalhos futuros na área de estudo e considerando que trabalhos de natureza geológica e geocronológica na área são escassos, sugerimos que se façam alguns trabalhos geocronológicos e tectônicos de base no cinturão Fíngoè, com vista a:

$\checkmark$ Entender a geologia e evolução tectônica do cinturão Fíngoè;

$\checkmark$ Datar o maior número possível de amostras na área, com vista à obtenção de uma idade de cristalização e dos eventos hidrotermais mais precisas; 
Estudos Petrográficos e Geocronológicos do Prospecto Mankombiti, Cinturão de Fíngoè, Província de Tete Noroeste de Moçambique.

$\checkmark$ Desenvolver um modelo geológico 3D para melhor visualização da mineralização em causa;

$\checkmark$ Definir com clareza os processos tectono-metamórficos Neoproterozóicos para uma melhor compreensão do modelo metalogenético a ser adotado. 


\section{6 - REFERÊNCIAS BIBLIOGRÁFICAS}

BABINSKI, M., 1993. Idades isocrônicas $\mathrm{Pb}-\mathrm{Pb}$ e geoquímica isotópica de $\mathrm{Pb}$ das rochas carbonáticas do Grupo Bambuí, na porção sul da bacia do São Francisco. Tese de Doutoramento, IPEN/USP, 133p.

CHRISTOPHER, P. A. (2010) Technical Report on the King Solomon's Mine Project, Mozambique, Africa. Location: Tete Province CENTERED NEAR 320000E 829600N (UTM, WGS 84).

DE PAOLO D.J., (1981) Neodymium isotopes in Colorado Front Range and crust-mantle evoluation in the Proterozoic. Department of Earth and Space Sciences, University of California, Los Angeles, California, USA. Vol.291, pp 1-4.

De PAOLO, D.J. (1988b). Neodymium isotope geochemistry: An introduction. Berlin; New York: Springer-Verlag. 187p.

DICKIN, A.P. (1995). Radiogenic Isotope Geology. Cambridge University Press. 490p.

EINAUDI, M.T., (1982a) Description of skarns associated with porphyry copper plutons. In: Titley SR (ed) Advances in geology of the porphyry copper deposits, southwestern North America. University of Arizona Press, Tucson, pp 139-184.

FAURE, G. \& MENSING, T.M. (2005). Isotopes: Principles and Applications ( $3^{\text {rd }}$ Edition ed.) Canadá: John Wiley \& Sons, Inc., Hoboken, New Jersey.

FAURE, G. (1986). Principles of Isotope geology. New York: John Wiley \& Sons. 589p.

GOSCOMBE, B., FEY, P. \& BOTH, F. 1994. Structural evolution of the Chewore Inliers, Zambezi Mobile Belt, Zimbabwe.Journal of African Earth Sciences 19, 199-224

GOSCOMBE, B.; ARMSTRONG, R. \& BARTON, J.M. (2000). Geology of the Chewore Inliers, Zimbabwe: constraining the Mesoproterozoic to Paleozoic evolution of the Zambezi belt. Journal of African Earth Sciences, 30:599-627.

GRANTHAM, G.H.; MABOKO, M. \& EGLINGTON, B.M. (2003). A review of the evolution of the Mozambique belt and implications for the amalgamation and dispersal of Rodinia and Gondwana. In: YOSHIDA, M.; WINDLEY, B.F. \& DASGUPTA, S. (eds). Proterozoic East Gondwana: supercontinent assembly and breakup. Geological Society, London, Special Publications, 206:401-425. 
GTK CONSORTIUM 2006. Map Explanation; Volume 4: Sheets 1430-1432 and 1530-1534. Geology of Degree Sheets Inhamambo, Maluwera, Chifunde, Zumbo, Fíngoè-Magoe, Songo, Cazula and Zobue, Mozambique. Direção Nacional de Geologia (DNG), Maputo, 382 p.

HANSON, R. E., WARDLAW, M. S., WILSON, T. J. \& MWALE, G.1993. U-Pb zircon ages from the Hook granite massif and Mwembeshi dislocation: constraints on Pan-African deformation,plutonism,and transcurrent shearing in central Zambia.Precambrian Research 63, 189-209.

HOSKIN PWO, BLACK LP (2000) Metamorphic zircon formation by solid-state recrystallization of protolith igneous zircon. J Metamor Geol 18:423-439.

HUNTING, Geology \& Geophysics 1984a. Ground Geophysics.Mineral Inventory Project in Tete Province and Parts of Manica, Sofala and Zambezia Provinces. Report on ground geophysical investigations for the 1982 and 1983 field season. Unpublished Report to DNG, Maputo.

HUNTING, Geology \& Geophysics 1984b. Landsat Interpretation - Stage 2. Mineral Inventory Project. Revised landsat interpretation, description of mapped units, Tete area. Unpublished Report to DNG, Maputo.

IRELAND, T.D. \& WILLIAMS, I.S. (2003). Considerations in zircon geochronology by SIMS. In: Hanchar, J.M. \& Hoskin, P.W.O. (ed): Zircon. Reviews In Mineralogy \& Geochemistry, $53: 215-242$.

JACOBS, J., BAUER, W. AND THOMAS, R. T. (2006). A Himalayan-type indentor-escape tectonic model for the southern part of the Late Neoproterozoic/Early Paleozoic East African-Antarctic Orogen. Colloquium of African Geology (CAG21), 03-06/07/2006, Maputo, Mozambique. Abstract Volume, 71-72.

JOHNSON, S.P.; RIVERS, T. \& DE WAELE, B. (2005). A review of the Mesoproterozoic to early Paleozoic magmatic and tectonothermal history of south-central Africa: implications for Rodinia and Gondwana. Journal of the Geological Society, London, 162:433-450

KEI SATO, MIGUEL A. S. BASEI, OSWALDO S. JÚNIOR, WALTER M. SPROESSER,CLÁUDIA R. PASSARELLI (2008); Novas Técnicas Aplicadas ao Método U-Pb 
no CPGeo - IGc/USP:Avanços na Digestão Química, Espectrometria de Massa (TIMS) e Exemplos de Aplicação Integrada com SHRIMP; Centro de Pesquisas Geocronológicas Instituto de Geociências - USP, São Paulo, SP, BR.

KRÖNER A, STERN R. J. (2004); Pan-African Orogeny North African Phanerozoic Rift Valley. Encyclopedia Of Geology (2004), vol. 1, Elsevier, Amsterdam;

LUDWIG, K.J. (2003). Isoplot. 3.00 Berkeley Geochronology Center. Special Publication, 4, $70 p$.

MÄNTTÄRI, I.(2008). Mesoarchaean to Low Jurassic U-Pb and Sm-Nd from NW Mozambique. Geological survey of Finland. Sepecial Pepe, 48:81-119.

MEERT, J.G. (2003). A synopsis of events related to the assembly of eastern Gondwana. Tectonophysics, 362:1-40.

MEINERT, L.D., DIPPLE GM, NICOLESCU, S. (2005) World skarn deposits. Econ Geol 100th Ann Vol: 299-336

PASSARELLI, C.R., BASEI, M.A.S., SIGA Jr. O., SATO, K., SPROESSER, W. M., LOIOS, V. A. P., 2009- Dating minerals by ID-TIMS geochronology at times of in situ analysis: selected case studies from the CPGeo- IGc-USP laboratory. Anais da academia Brasileira de Ciências, 81, $1-25$.

PIRAJNO; F. (2009) - Hydrothermal Processes and Mineral Systems. Geological Survey of western Australia, Perth, WA, Australia. Springer science + Business media B.V.

SATO, K.; TASSINARI, C.C.G.; KAWASHITA, K. \& PETRONILHO, L. (1995). O método geocronológico Sm-Nd no IGC/USP e suas aplicações. Anais da Academia Brasileira das Ciências, 67:313-336.

SATO, K.; TASSINARI C.C.G. (1997) Principais eventos de acreção continental no Cráton Amazônico baseados em idade-modelo $\mathrm{Sm}-\mathrm{Nd}$, calculada em evoluções de estágio único e estágio duplo. In: COSTA, ML; ANGÉLICA,R.S (coords.). Contribuições à geologia da Amazônia, Belém, SBG. V.1, p. 91-142

SHACKLETON, R.M. (1994). The final collision zone between East and West Gondwana; where is it? Journal of African Earth Sciences, 23(3):271-287. 
STACEY J.S, KRAMER'S J.D, 1975. Approximation of terrestrial lead isotope evoluation by two-stage model. Earth and planetary science letters, 26: 207-221

STERN, R.J. (2004). Arc assembly and continental collision in the Neoproterozoic East Africa Orogen: Implications for the consolidation of Gondwanaland. Annual Revs. Earth and Planetary Scinces, 22:319-351.

TASSINARI, C.C.G.; MEDINA, J.G.C. \& PINTO, M.C.S. (1996). Rb-Sr and Sm-Nd geochronology and isotope geochemistry of Central Iberian metassedimentary rocks (Portugal). Geologie en Mijnbouw, 75:69-79.

WESTERHOF, A. B. PHIL, LEHTONEN, M. I., MAKITIE, H., MANNINEN, T., PEKKALA, Y.,GUSTAFSSON, B. \& TAHON, A. 2008. The Tete-Chipata Belt: a new multiple terrane element from western Mozambique and southern Zambia. Geological Survey of Finland,Special Paper 48, 145-166.

WILSON, T.; GRUNOW, A.M. \& HANSON, R.E. (1997). Gondwana assembly: The view from southern Africa and East Gondwana: Journal of Geodynamics, 23:263-286.

ZARTMAN R.E \& DOE B.R 1981. Plumbotectonics - the model. Tectonophysics, 75: 135-162 
Estudos Petrográficos e Geocronológicos do Prospecto Mankombiti, Cinturão de Fíngoè, Província de Tete Noroeste de Moçambique.

\section{ANEXOS}




\section{ANEXO - I \\ DESCRIÇÃO PETROGRÁFICA PRELIMINAR}

\section{FURO MW02}




\section{AMOSTRA MW02/005P}

O granito macroscopicamente apresenta cor róseo com tons verdes, com textura inequigranular, onde se observam megacristais de feldspato vermelho em granulação aproximada entre 2-3 mm, intercrescidos com minerais máficos de tamanho entre $0.5-1,0 \mathrm{~mm}$ de cor verde escuro. A amostra apresenta uma mancha verde claro, produto de alteração hidrotermal no estilo semipervasivo a pervasivo, pois apresenta ainda algumas relíquias de rocha nas laterais. Microscopicamente apresenta uma textura hipidiomorfica granular. Os minerais primários presentes na amostra são: piroxênio plagioclásio. O plagioclásio mostram-se subeuédricos a euédricos com tamanhos que variam entre 0,5 e $4 \mathrm{~mm}$ e ocorrem na matriz. Estes cristais ocorrem em duas fases. A primeira é marcada por megacristais euédricos e zonados e geminados segundo a lei da Albita e carlsbad. A segunda fase os cristais de plagioclásio encontram-se pervasiva a parcialmente alterados em epidoto (em maior porcentagem) e carbonato. Em algumas porções da lamina é notória a carbonatação fissural. Os cristais de piroxênio com habito prismático e ocasionalmente arredondados e euédricos e bem cristalizados, com tamanhos que variam de 1 a $3 \mathrm{~mm}$, em algumas partes da lamina ocorrem como pórfiros e estão se alterando para o epidoto bem na fase inicial; A actinolita $(>0,01 \%)$ aparece como cristais alongados e em contato com os piroxênios; A clorita aparece preenchendo interstícios e por vezes inclusa na biotita; Microclinio ocorre como cristais anédricos geminados segundo as leis de carlsbad e albita, esta ultima superposta à Carlsbad. Aparece em contato com o plagioclásio e o epidoto e esta bastante alterado. Alguns se apresentam pertiticos. Os cristais de anfibólios são euédricos com um habito prismático estão parcial ou totalmente substituídos por epidoto, em alguns casos são notáveis os cristais de anfibólio bem no inicio da alteração em epidoto. O quartzo ocorre em cristais anédricos e com contatos irregulares e apresenta extinção ondulante. É encontrado em forma de veios e preenchendo interstícios. Associação de minerais de alteração presentes nesta rocha são epidoto + carbonato podendo pertencer a alteração propilitica.

\section{AMOSTRA MW02/011P}

O gabro possui uma cor cinza esverdeada com pequeníssimos grãos dourados indicando a presença de sulfetos. É uma rocha maciça, holocristalina, com textura inequigranular, de 
granulação aproximadamente entre $0,5-1,5 \mathrm{~mm}$ dentro de uma matriz fina. É constituída por quartzo, cristais tabulares de piroxênio e minerais opacos. Os minerais secundários comuns são clorita, epidoto, carbonato, actinolita. Os piroxênios mostram-se em grãos euédricos, com pleocroísmo fraco (verde- verde claro), com tamanho entre 1 e 3mm. Ocorrem amplamente dispersos no litotipo, associados a minerais opacos. Os cristais de plagioclásio são intensamente substituídos por clorita, preenchendo interstícios. Apresenta um processo de cloritização, muito expressivo, caracterizado pelo estilo pervasivo preenchendo espaços entre os grãos espalhados pela rocha. A clorita esta em contato com a actinolita e carbonato, onde se pode obter a associação de actinolita + clorita + calcita +quartzo. O anfibólio é anédrico, e mostra pleocroísmo de verde a verde claro. Exibem contatos irregulares com os piroxênios, e estão parcialmente alterados em actinolita. O quartzo ocorre em cristais anédricos, com contatos irregulares, são comuns os agregados granulares e apresenta extinção ondulante. Os minerais opacos aparecem dispersos no litotipo e associados aos anfibólios.

\section{AMOSTRA MW02/014P}

O granito apresenta cor rósea com tons verdes, e uma assembleia mineral dominada por microclínio ortoclásio, plagioclásio e clinopiroxênio como minerais essenciais, enquanto que a titanita é o mineral acessório mais comum encontrado. Esta rocha com foliação exibe textura porfirítica. O microclinio ocorre como porfiroclasto, com efeitos visíveis de deformação nas bordas e em alguns casos são também visíveis exsoluções de lamelas de albita. O feldspato alcalino (ortoclásio) ocorre como cristais subdiomórficos em contato entre si e com o piroxênio com inclusões de plagioclásio, biotita e quartzo. O plagioclásio ocorre completamente alterado em sericita. Esta sericitização ocorre no estilo seletivo pervasivo em que a sericita oblitera totalmente a textura inicial da rocha por vezes parcial. O clinopiroxênio ocorre se alterando em Epidoto, esse processo de Epidotização é notório nas bordas do clinopiroxênio e preenchendo clivagens do mesmo.

\section{AMOSTRA MW02/029PO}


O gabro anoritico apresenta cor cinza esbranquiçada com algumas manchas douradas espalhadas pela amostra que indicam a presença de algum sulfeto. Estrutura maciça, textura afanitica inequigranular, pouco foliada dada pela actinolita e piroxênio, de grão fino. A assembleia mineral é constituída por piroxênio que apresenta cristais preservados sem muita alteração, em grãos anédricos, por vezes como pórfiros, incluindo minerais opacos, estes por sua vez aparecem preenchendo espaços entre os cristais de piroxênio. A actinolita ocorre como produto de alteração do piroxênio, presente em alguns pontos da rocha. $\mathrm{O}$ carbonato aparece como produto de alteração do plagioclásio, este processo ocorre em duas gerações de carbonato: o carbonato 1 é calcita que invadi a assembleia mineral composta por cristais de piroxênio e preenche os interstícios; o carbonato 2 preserva as estruturas das maclas de carlsbad encontradas no plagioclásio.

\section{AMOSTRA MWO2/030PO}

O micro gabro, macroscopicamente apresenta-se heterogênea maciça, de cor cinza esbranquiçada, com tons de cinza escuros e pequenos grãos de um cristal dourado, evidenciando a presença de sulfetos. É caracterizada principalmente pelo processo de saussuritização, em que o plagioclásio encontra-se completamente alterado em clorita, que compõe a matriz da rocha. A assembleia mineral presente é: clorita, carbonato, actinolita e opacos.

A clorita esta presente na matriz da rocha e perfaz entre 40-60\% da amostra, dando a ela uma textura lepidoblástica, principalmente quando a clorita aparece associada ao carbonato e actinolita, mas aparece sem orientação preferencial em muitos pontos do litotipo. É encontrada também como mineral intersticial na actinolita e carbonato.

A actinolita aparece em contato com a clorita e opacos, e como produto de alteração do piroxênio e que ainda preservam em alguns casos formas prismática do piroxênio. Os opacos apresentam-se como pórfiros na matriz. O quartzo, em pequena porcentagem $(<1 \%)$ com extinção ondulante são anédricos com contatos irregulares e ocorrem como agregados imbricados entre si.

\section{AMOSTRA MW02/30PO2}


O micro gabro macroscopicamente apresenta cor cinza esbranquiçada, bastante heterogênea e maciça, com tons escuros e brancos, os minerais dourados, encontram-se dispersos por todo litotipo, como inclusões ou interstícios nas partes brancas da amostra.

Microscopicamente é composta por clorita, carbonato, actinolita, e opacos. A clorita compõe cerca de $40 \%$ da matriz da amostra, sem orientação e por vezes com orientação, quando associada à actinolita-carbonato, tendo nesses locais uma matriz lepidoblástica. Por vezes aparece inclusa na actinolita e com bolsões de minerais opacos no meio. A actinolita aparece em pequenas proporções encontra-se em contato com o carbonato, por vezes essa associação é encontrada no meio de minerais opacos, preservando as formas de piroxênio. Esta alteração do piroxênio em actinolita é do tipo selectiva- pervasiva, com algumas ocorrências de alterações não pervasiva mais do tipo fissural. O carbonato aparece como vênulas no meio de minerais opacos e por vezes dentro da clorita e em contato com a actinolita. Os opacos estão presentes na matriz e carbonato e clorita. Nesta amostra o processo de alteração presente é a propilitica, dada pelos minerais de alteração clorita + carbonato+ opacos.

\section{AMOSTRA MW02/036PO}

O gabro de cor cinza esbranquiçada, com alternância de partes escuras, e pequeníssimos cristais dourados espalhados pela amostra. É heterogênea, maciça de grão fino. Microscopicamente é constituída por: clorita, epidoto, piroxênio e quartzo.

A clorita perfaz cerca de $40 \%$ da matriz, apresentam-se cristalizada sem orientação preferencial e com orientação quando associada à actinolita-carbonato. Esta ultima confere a rocha uma textura lepidoblástica. A clorita é encontrada como mineral intersticial entre os pseudomorfos de piroxênio, actinolita e carbonato. O epidoto é encontrado na amostra em contato entre os minerais de carbonato e clorita, e por vezes como finas vênulas associadas às vênulas de carbonato e clorita. O carbonato ocorre em forma de vênulas com cristais recristalizados, como produto de alteração fissural, associado ao piroxênio. O piroxênio perfaz cerca de $60 \%$ da amostra, são anedricos, com tamanhos entre 0,5 a $3 \mathrm{~mm}$, ocorrem como pórfiros e estão associados a minerais opacos, entre os grãos de piroxênio aparece a clorita e o epidoto, o carbonato em forma de pequenas vênulas. 


\section{FURO MW03}

Com a profundidade total de $133,87 \mathrm{~m}$, é composta por três amostras de um modo geral de cor cinza esbranquiçada a cinza escura, maciça de grão médio a fino:

\section{AMOSTRA MW03/001PO}

De cor cinza esbranquiçada, encontra-se na profundidade entre $37,16 \mathrm{~m}$ a $37,39 \mathrm{~m}$ e com um comprimento de 0,23m apresenta cristais com tamanhos que variam entre 2-3 mm de calcita e dolomita imbricados entre si, com clivagem romboédrica, alta birrefringência associada à dolomita, contem quartzo em pequenas quantidades e algumas intrusões de anfibólio uma textura granoblástica poligonizada.

\section{AMOSTRA MW03/017PO}

Rocha de cor cinza esverdeada, na profundidade entre 72,82 m e 73,22. É representada essencialmente pelo piroxênio (65\%) anédrico a euédricos, e esta se transformando em actinolita. A foliação é observada nos cristais de piroxênio e opacos (30-40\%). A cloritização ocorre nas bordas do minério e ao longo dos veios de carbonato. A clorita esta associada a minerais opacos, e não apresentam orientação preferencial. Os minerais opacos ocorrem dispersos por toda a amostra, e com inclusões de carbonato-clorita.

A carbonatação é muito expressiva e ocorre no estilo fissural pervasiva juntamente com a serpentina cortando os opacos. O estilo fissural caracteriza-se pelo preenchimento de fraturas de forma irregular por carbonato. A rocha exibe uma textura holocristalina.

\section{AMOSTRA MW03/033PO}

Rocha de cor cinza esbranquiçada, na profundidade entre 81,35m e 81,46m a composição predominante é o piroxênio (65\%), com variação de tamanho e forma prismática, o plagioclásio (35\%) aparece se alterando para a sericita, o quartzo (10\%) em forma de veios, e como mineral acessório ocorre o espinélio. A sericitização apresenta-se pouco desenvolvido e de pouca abrangência no meta-gabro anoritico. Nesta rocha é representado pela assembleia sericita \pm quartzo que substituem parcial ou totalmente o feldspato, sendo o mais comum o plagioclásio. Observa-se nesta amostra uma textura porfirítica. 


\section{AMOSTRA MW04/002P}

Granito de cor rosa a esverdeada, de grão médio a grosseiro, compacta textura granular, apresenta uma assembleia mineral dominada por microclínio, ortoclásio, plagioclásio e hornblenda como minerais essenciais, enquanto que a titanita é o mineral acessório comumente encontrado nesta amostra. Os cristais de feldspato alcalino ocorrem como pórfiros em tamanhos que variam de $2 \mathrm{~mm}$ a $3 \mathrm{~cm}$. Estes cristas são euédricos a euédricos com contatos retos por vezes irregulares entre os grãos. Apresentam pertita do tipo vênulas muito expressiva, e estão geminados segundo a lei de carlsbad em alguns cristais da amostra. Observam-se também frequentemente as maclas de albita-periclina dadas pelo microclinio. Os anfibólios (hornblenda) são euédricos e em contatos retos e por vezes geminados com pleocroísmo de verde a castanho. Ocorre em alguns destes cristais o processo de biotitização, pervasiva fraca. O plagioclásio esta alterado em sericita e tem estilo pervasivo seletivo. A biotita ocorre como cristas anédricos e mostram pleocroísmo que varia de castanho-verde a castanho. Estes cristais estão associados ao anfibólio. Os minerais opacos ocorrem em poucas quantidades e estão associados as micas e anfibólios. O quartzo aparece em forma de cristais anédricos, em contatos irregulares e preenchendo interstícios (entre os feldspatos). Apresenta extinção ondulante. Mineral acessório encontrado é a titanita.

\section{AMOSTRA MW05/001PO}

Brecha carbonática de cor cinza esbranquiçada com tons pretos e alguns grãos de minerais dourados (sulfetos), estrutura bandada e maciça de grão fino, apresenta uma textura holocristalina. A assembleia mineralógica é composta por dolomita, feldspato alcalino e actinolita. A amostra é composta maioritariamente por uma matriz de composição carbonática e textura cripto-microcristalina com fragmentos de carbonato. $\mathrm{O}$ carbonato aparece em cristais grandes $(2 \mathrm{~cm})$ anédricos, com inclusões de vários minerais com variação de tamanho, esta em contato irregular com os minerais opacos. Actinolita ocorrem como cristais euédricos e dispersos. Este aparece como produto de alteração do piroxênio, e ainda preserva as formas prismáticas da mineral inicial. Anfibólios são euédricos e mostram pleocroísmo de verde escuro a castanho claro. Exibem um contato reto e por vezes aparecem geminados, em geral eles ocorrem dispersos na rocha em cristais pequenos, associados ao piroxênio e como inclusões nos 
minerais opacos. Clorita, com habito acicular, ocorre como agregados em determinados cantos da matriz e associados aos opacos. O quartzo aparece em formas de pequenos cristais imbricados entre si, com a extinção ondulante e por vezes inclusa aos cristais carbonáticos.

\section{AMOSTRA ME05/002P}

Gabro apresenta cor cinza a verde escuro, estrutura maciça, textura afanitica inequigranular, foliação dada pela clorita-xisto, de grão fino. A assembleia mineral é constituída por cloritaxisto, feldspato, biotita e quartzo. A cloritização é muito abrangente e é responsável pela coloração verde escuro da rocha. Esta representada por clorita com uma birrefringência em tons de castanho, provavelmente sobrepondo a alteração sericítica e carbonática. Esta distribuída nos interstícios dos grãos de plagioclásio. Esta clorita é responsável pela textura nematoblástica da amostra. Plagioclásios apresentam geminação polissinténtica e alguns senguem esse lineamento e outros não, como bolsões envolvidos pelos minerais ferro magnesianos. É notória a alteração desses minerais em epidoto, e por vezes no núcleo deles, é possível observar a clorita e o epidoto. O quartzo ocorre em pequenos cristais anédricos com extinção ondulante.

\section{AMOSTRA ME05/003P}

Leucogabro?? Rocha de cor cinza esbranquiçada com tons verdes, maciça, textura holocristalina de grão médio a fino, a assembleia mineral é constituída principalmente por cristais alterados plagioclásio, biotita e piroxênios com baixa a moderada birrefringência. Esta amostra caracteriza-se por uma alteração composta por albita+ clorita+ epidoto \pm biotita (relíquias). O plagioclásio ocorre como cristal subeuédricos tabular de tamanhos grandes, com albita nas bordas, nos núcleos é possível ver o epidoto e pequenos cristais de clinozoisita. Esse processo de epidotização é pervasivo e atinge os cristais de piroxênio e plagioclásio. A biotita ocorre em agregados provavelmente seja hidrotermais formadas a partir de cristais de piroxênio. A clorita ocorre entre os cristais de piroxênio alterados e com um pouco de biotita entre elas. Provavelmente por um processo tardio de temperatura baixa, houve a formação de clorita com relíquias de biotita. 


\section{AMOSTRA ME06/001P}

Gabro que apresenta um a cor cinza esbranquiçada que com tons cinza escuro e pequenas vênulas de um cristal dourado, evidenciando a presença de sulfetos, de estrutura maciça. Microscopicamente é composto por:

Feldspato alcalino, com dimensões inferiores a $0,4 \mathrm{~mm}$, subordinantes a matriz. São anédricos, e com contatos irregulares com os cristais de anfibólio. O processo de sericitização esta patente neste mineral em alguns pontos da amostra. $\mathrm{O}$ plagioclásio em tamanhos pequenos que variam de 0.5 a $1 \mathrm{~mm}$, mostram-se euédricos a subeuédricos ocorrendo na matriz, e obedecem a lei albita-carlsbad, nos poucos cristais que são possíveis de observar nota-se ausência de deformação como formação de um outro grau ou quebramento, o que pode indicar que estes plagioclásios tenham sido gerados no magma inicial. O quartzo ocorrem em forma anédricas, com tamanhos maiores $(2 \mathrm{~mm})$ formam agregados com interstícios de mineral opacos, estão dispersos por toda a amostra e em contatos irregulares com o anfibólio; A biotita ocorre dispersa na matriz, associada ao anfibólio .

O anfibólio tem cor verde, mostra um pleocroísmo de verde escuro a castanho claro, exibindo contatos irregulares. Ocorre em 2 tipos,: anfibólio 1 ocorre como cristais neoformados e aprecem em agregados, enquanto que o anfibólio 2 resulta da alteração do clinopiroxênio. 


\section{ANEXO - II \\ GRÁFICOS DE EDS}
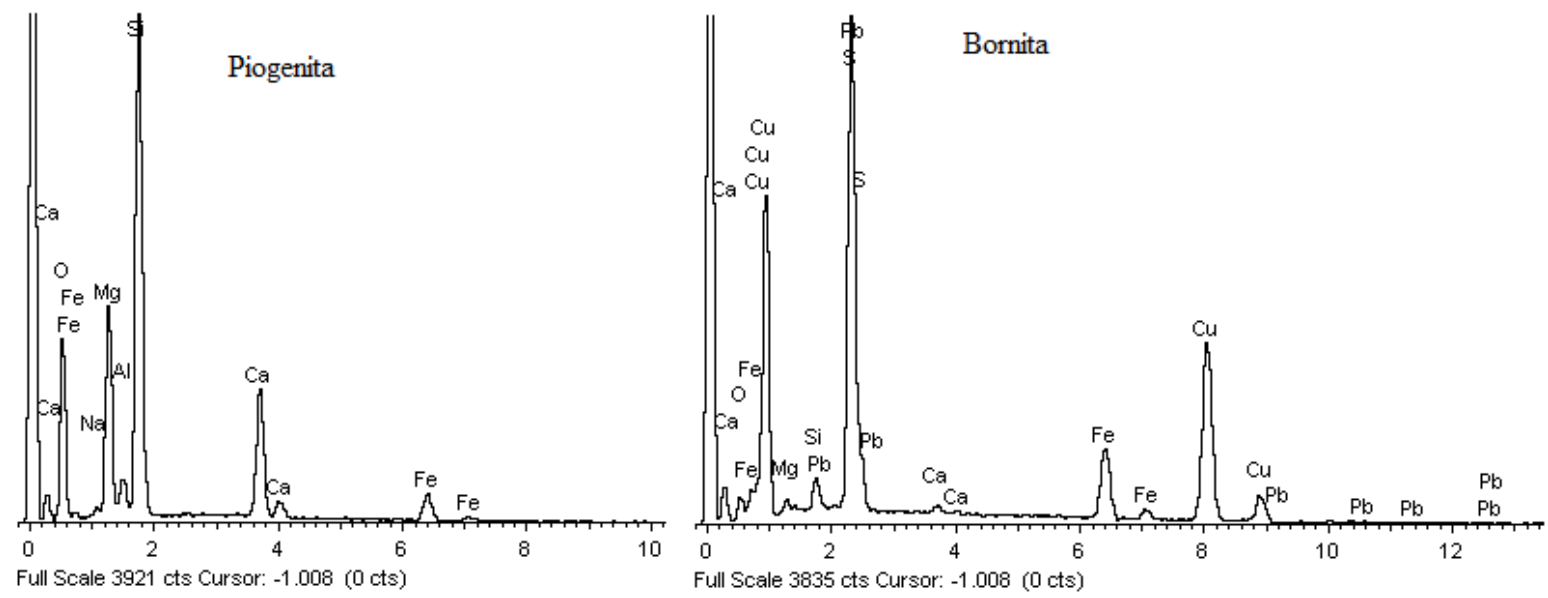

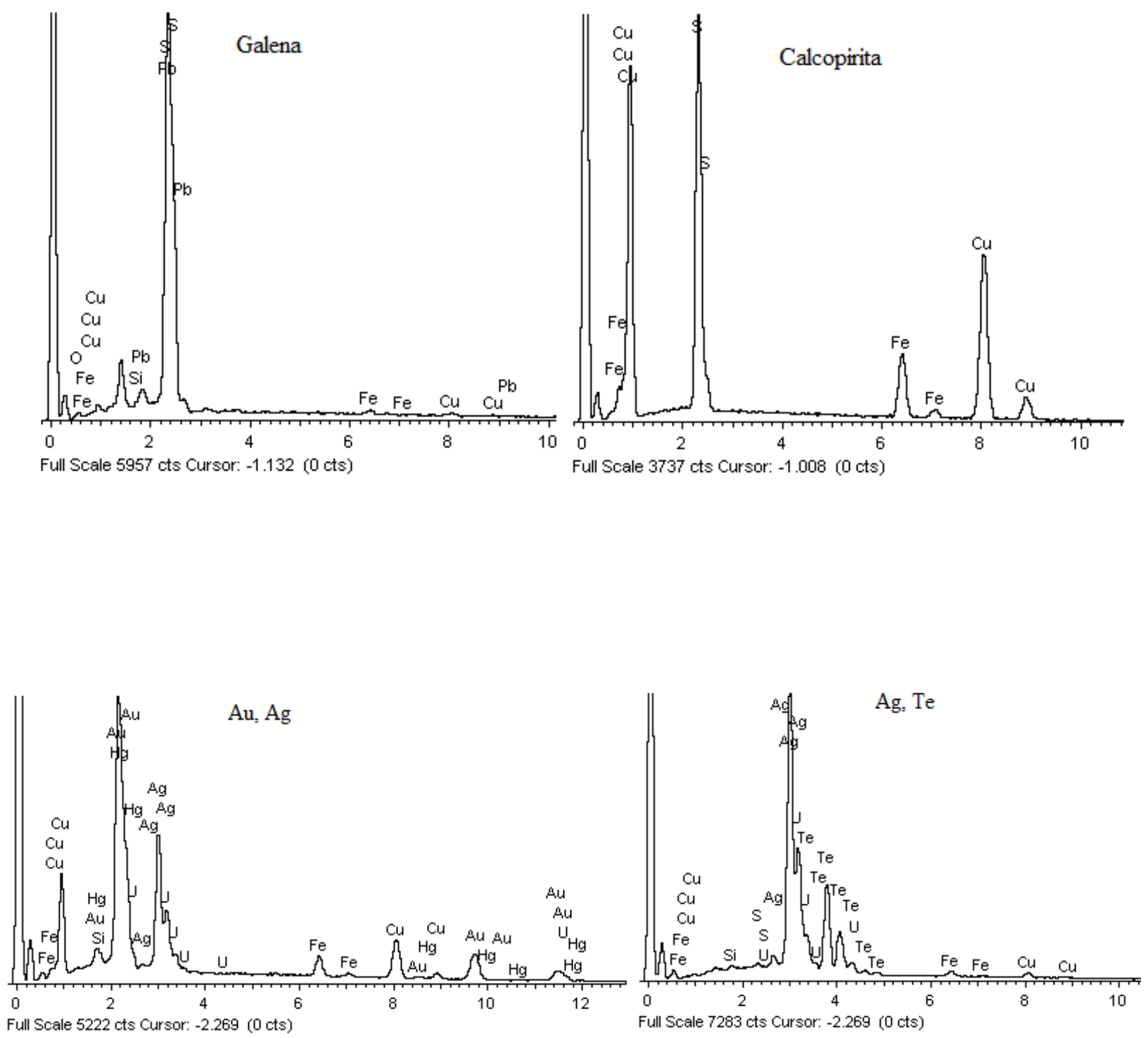


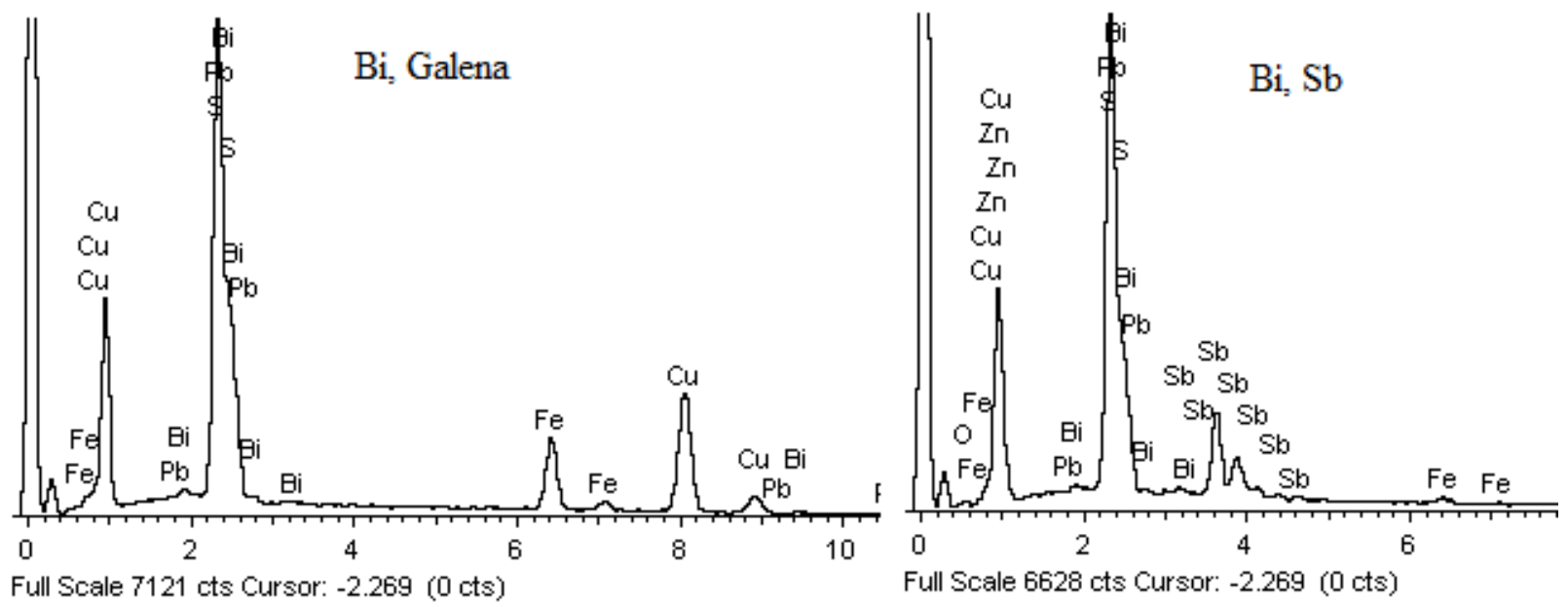

